\title{
AVALIAÇÃO DE DIFERENTES COBERTURAS DO SOLO NO CONTROLE DA EROSÃO EM TALUDES DE ESTRADAS FLORESTAIS
}

\section{CINTIA RODRIGUES DE SOUZA}

Engenheira Florestal

\author{
Orientador: Prof. Dr. FERNANDO SEIXAS
}

Dissertação apresentada à Escola Superior de Agricultura 'Luiz de Queiroz", Universidade de São Paulo, para obtenção do título de Mestre em Ciências, Área de Concentração: Ciências Florestais.

PIRACICABA

Estado de São Paulo - Brasil

Julho -2000 
ERRATA

Página 55

Tabela 14. Escoamento superficial, em mm, para os tratamentos analisados.

\begin{tabular}{|c|c|c|c|c|}
\hline Período & Testemunha & Grama & Casca & Tela \\
\hline $1-21 \mathrm{Jan} / 99$ & 5,40 & 2,40 & 0,50 & - \\
\hline $21 \mathrm{Jan}-2 \mathrm{FeV}$ & 4,20 & 3,19 & 0,00 & - \\
\hline $2-8 \mathrm{Fev}$ & 6,00 & 4,40 & 1,93 & - \\
\hline $8-12 \mathrm{FeV}$ & 4,90 & 3,54 & 5,29 & - \\
\hline $12-23 \mathrm{FeV}$ & 5,90 & 8,49 & 9,97 & - \\
\hline $23 \mathrm{FeV}$ - $2 \mathrm{Mar}$ & 8,10 & 9,99 & 11,07 & - \\
\hline 2-18 Mar & 0,70 & 1,70 & 3,36 & 0,54 \\
\hline $18 \mathrm{Mar}-1 \mathrm{Abr}$ & 5,20 & 4,99 & 7,76 & 3,64 \\
\hline $1-20 \mathrm{Abr}$ & 7,26 & 9,57 & 11,00 & 7,06 \\
\hline $20 \mathrm{Abr}-18 \mathrm{Mai}$ & 1,01 & 0,83 & 1,73 & 1,11 \\
\hline 18 Mai - 9 Jun & 0,43 & 0,73 & 1,16 & 0,76 \\
\hline 9 Jun -13 Jul & 5,57 & 5,94 & 9,30 & 5,30 \\
\hline $13 \mathrm{Jul}-2$ Set & 1,23 & 0,33 & 0,51 & 0,60 \\
\hline $2-23$ Set & 6,01 & 5,07 & 8,71 & 3,67 \\
\hline 23 Set -18 Out & 1,24 & 1,56 & 3,70 & 1,63 \\
\hline $18 \mathrm{Out}-26 \mathrm{Nov}$ & 1,94 & 2,87 & 3,83 & 1,97 \\
\hline 26 Nov $-5 \mathrm{Jan} / 00$ & 7,17 & 8,83 & 11,61 & 5,87 \\
\hline Subtotal $^{1}$ & 37,76 & 42,42 & 62,67 & 32,15 \\
\hline Total & 72,26 & 74,43 & 91,43 & 32,15 \\
\hline
\end{tabular}

1 Refere-se ao total do escoamento superficial produzido somente nas coletas onde todos os tratamentos estavam presentes. 


\title{
Dados Internacionais de Catalogação na Publicação (CIP) DIVISĀO DE BIBLIOTECA E DOCUMENTAÇĀO - Campus "Luiz de Queiroz"/USP
}

\author{
Souza, Cintia Rodrigues de \\ Avaliaçāo de diferentes coberturas do solo no controle da erosão em taludes de \\ estradas florestais / Cintia Rodrigues de Souza. - - Piracicaba, 2000. \\ 90 p. : il. \\ Dissertação (mestrado) - - Escola Superior de Agricultura Luiz de Queiroz, 2000. \\ Bibliografia. \\ 1. Cobertura do solo 2. Erosão 3. Estrada florestal 4. Estrada rural I. Título
}

CDD 634.986 
Aos meus pais Wilson (in memorian) e Alzira,

Aos meus irmãos Leandro e Rodrigo,

À minha avó Carmela,

Ao meu padrasto Élcio,

Ao Rogério 


\section{AGRADECIMENTOS}

Ao Prof. Dr. Fernando Seixas pela orientação, amizade e apoio, sem os quais este trabalho não teria sido possível,

Ao Prof. Dr. Walter de Paula Lima, pelas importantes e valiosas sugestões,

À Dra. Maria José Brito Zakia, pela amizade, dedicação e por sua inestimável colaboração na execução deste trabalho,

Ao Prof. Dr. João Luís Ferreira Batista, pela grande contribuição na análise estatística,

À técnica de laboratório Alba Valéria Masetto e demais funcionários do Laboratório de Ecologia Aplicada da ESALQ/USP, pela ajuda nas análises de laboratório,

À Votorantim Celulose e Papel S/A, na pessoa dos engenheiros Fausto Rodrigues Alves de Camargo e Cláudio Roberto Silva, pelo enorme apoio material e em recursos humanos, e ao técnico Dimas Donizete Patrocínio pelo auxilio na montagem do experimento e nas coletas de material,

À Defesa Florestal Ltda., que gentilmente cedeu sua tela vegetal ARP-430, um dos tratamentos analisados neste trabalho,

À Fundação de Amparo à Pesquisa do Estado de São Paulo (FAPESP), pelo apoio material representado pelos recursos da reserva técnica e pela bolsa concedida,

À Coordenação de Aperfeiçoamento de Pessoal de Nível Superior (CAPES), pela bolsa concedida,

A todos aqueles que tiveram seus nomes aqui involuntariamente omitidos, mas que colaboraram para a realização deste trabalho. 


\section{SUMÁRIO}

Página

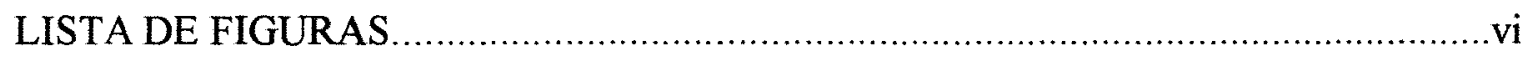

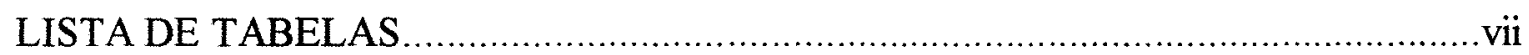

RESUMO

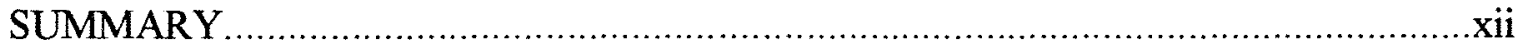

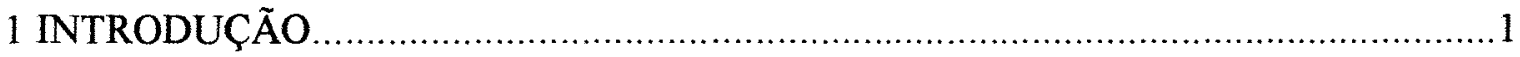

2 REVISÃO DE LITERATURA

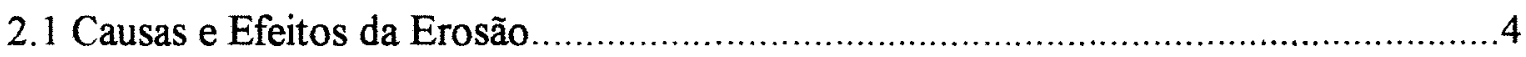

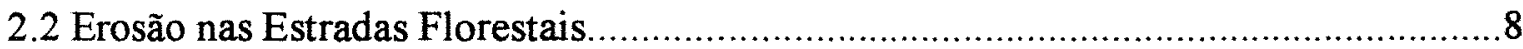

2.3 Implicações na Qualidade da Água e na Perda de Nutrientes...................................15

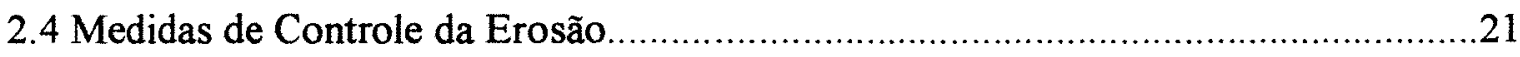

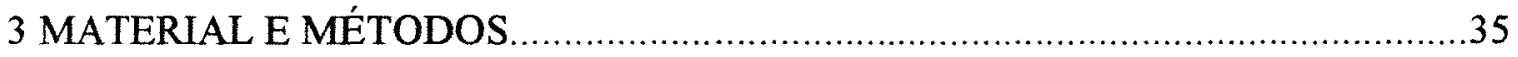

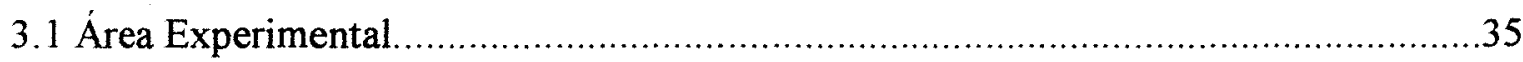

3.1.1 Clima

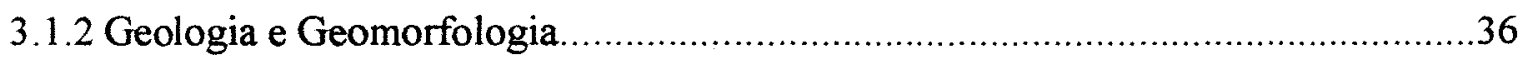

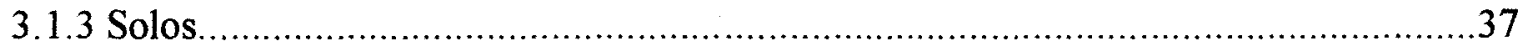

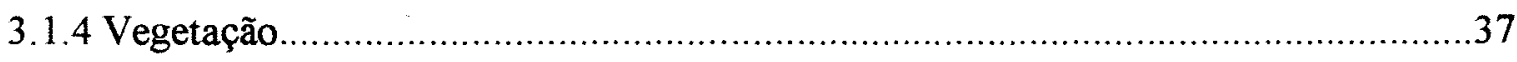

3.2 Métodos

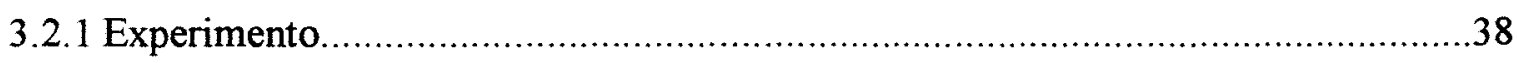

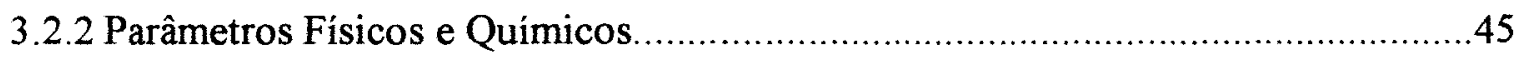

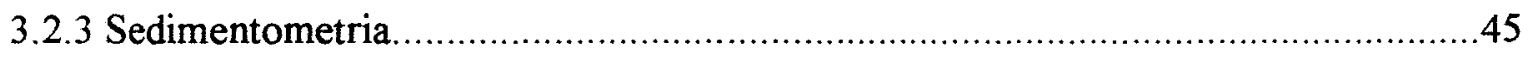

3.2.4 Avaliação da Taxa de Cobertura das Parcelas.......................................................46 


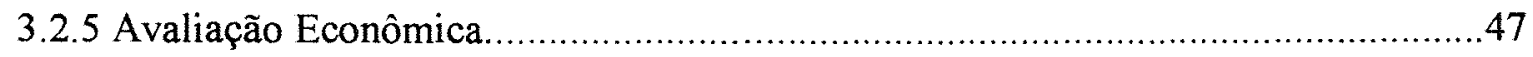

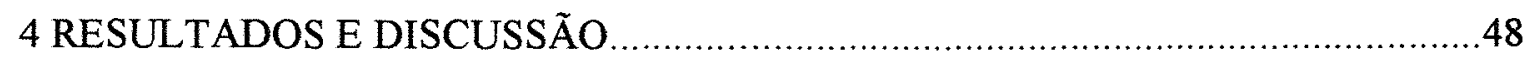

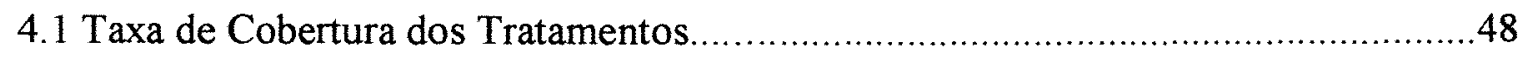

4.2 Produção de Sedimentos e Escoamento Superficial...................................................49

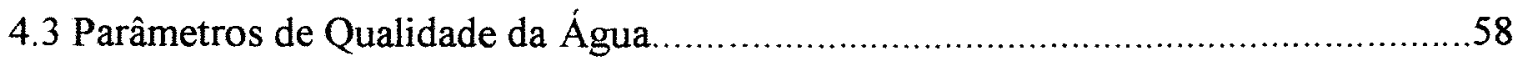

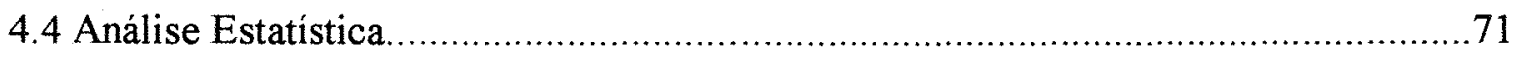

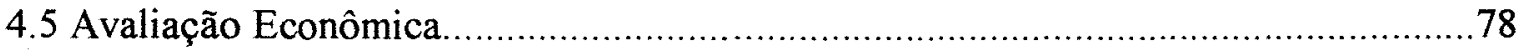

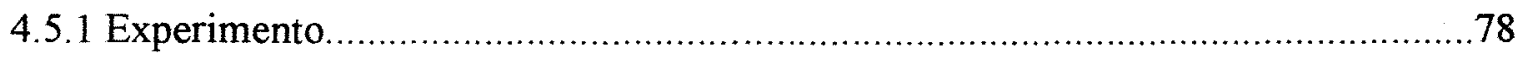

4.5.2 Instalação dos Tratamentos em uma Área de 1 ha a uma Distância de $20 \mathrm{~km}$........78

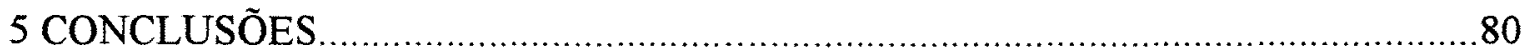

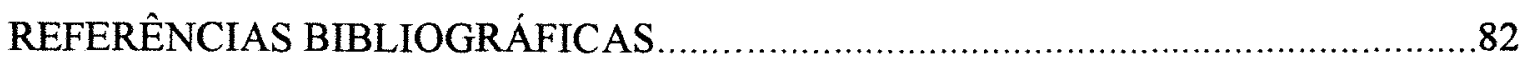




\section{LISTA DE FIGURAS}

Página

1 Precipitação mensal durante o período experimental........................................36

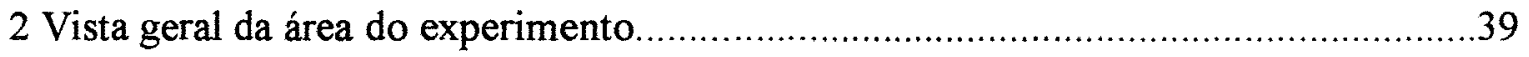

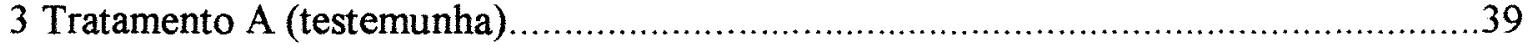

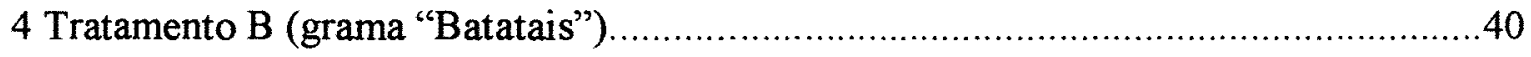

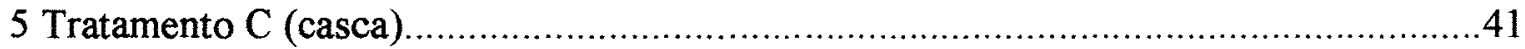

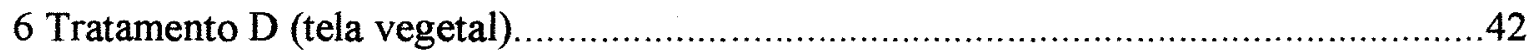

7 Estaca de bambu utilizada na fixação dos Tratamentos B e C no talude....................43

8 Grampo utilizado para fixação do Tratamento D no talude..................................44

9 Comparação entre a taxa de cobertura e a produção de sedimentos para o

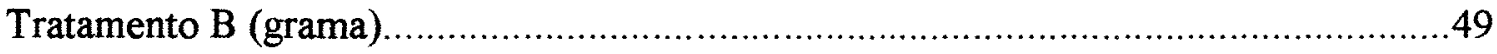

10 Produção total de sedimentos em t/ha para os tratamentos analisados...................53

11 Produção total de sedimentos para os Tratamentos B (grama), C (casca) e

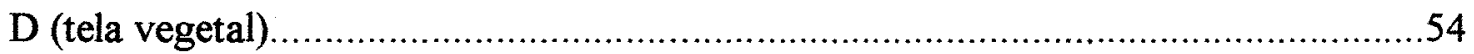

12 Escoamento superficial, em mm, para os tratamentos analisados..........................56

13 Valores médios de cor $(\mathrm{PtCo})$ para os tratamentos analisados.............................60

14 Valores médios de condutividade elétrica $(\mathrm{mS} / \mathrm{cm})$ para os tratamentos

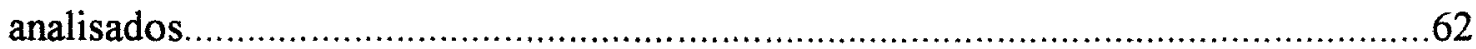

15 Valores médios de turbidez (FTU) para os tratamentos analisados.....................64

16 Valores médios de alcalinidade $(\mathrm{mg} / \mathrm{L})$ para os tratamentos analisados................66

17 Valores médios de $\mathrm{pH}$ para os tratamentos analisados.......................................68

18 Parcela do Tratamento D (tela vegetal) onde a germinação das

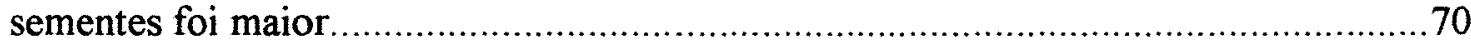

19 Detalhe da parcela mostrada na figura anterior............................................... 70 


\section{LISTA DE TABELAS}

Página

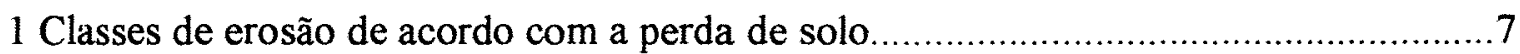

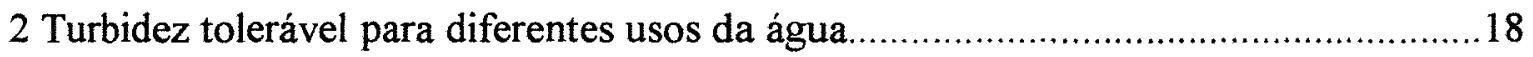

3 Produção de sedimentos devido à erosão superficial em estradas por número

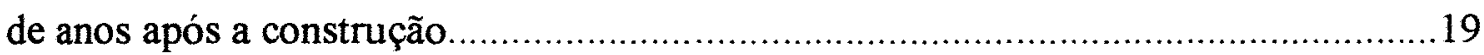

4 Valores dos parâmetros físicos e químicos observados antes e após o corte

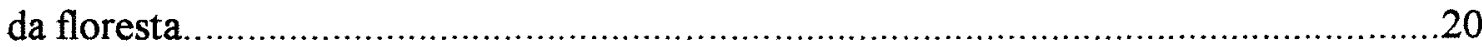

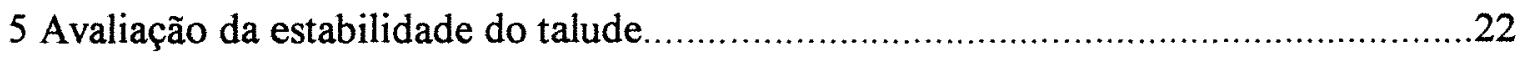

6 Efeito do tipo de uso do solo sobre as perdas por erosão ...........................................27

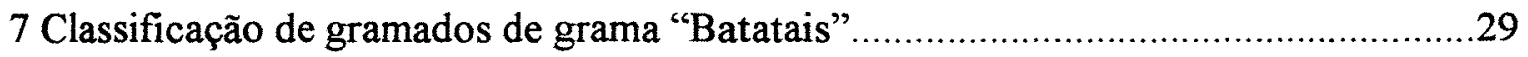

8 Eficiência dos tratamentos citados acima no controle da erosão, considerando $50 \%$ de cobertura do solo para todos os tratamentos..................................................

9 Medidas de controle da erosão pela estabilização de taludes em

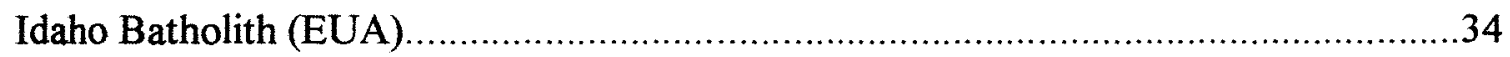

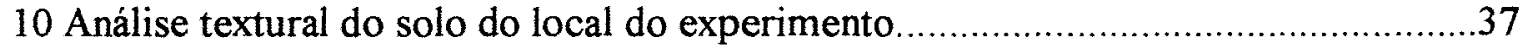

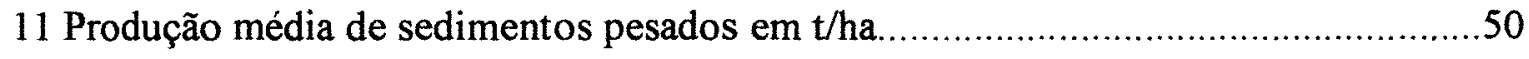

12 Produção média de sedimentos em suspensão em t/ha...........................................51

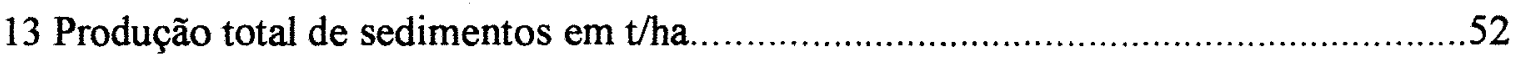

14 Escoamento superficial, em mm, para os tratamentos analisados............................55

15 Escoamento superficial em relação à precipitação (\%) para os tratamentos

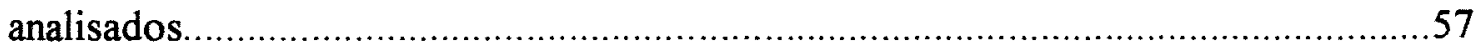

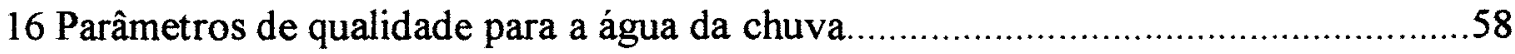

17 Valores médios de cor $(\mathrm{PtCo})$ para os tratamentos analisados................................59

18 Valores médios de condutividade elétrica $(\mathrm{mS} / \mathrm{cm})$ para os tratamentos analisados. 
19 Valores médios de turbidez (FTU) para os tratamentos analisados...........................63

20 Valores médios de alcalinidade $(\mathrm{mg} / \mathrm{L})$ para os tratamentos analisados...................65

21 Valores médios de $\mathrm{pH}$ para os tratamentos analisados...........................................67

22 Diferença entre os valores de sedimentos totais considerando somente os valores obtidos a partir do mês de março/1999, quando todos os tratamentos estavam instalados.

23 Diferença entre os valores de sedimentos totais considerando todos os valores obtidos no experimento, excetuando-se o Tratamento $\mathrm{D}$ (tela vegetal).

24 Diferença entre os valores de escoamento superficial considerando somente os valores obtidos a partir do mês de março/1999, quando todos os tratamentos estavam instalados. .72

25 Diferença entre os valores de escoamento superficial considerando todos os valores obtidos no experimento, excetuando-se o Tratamento $D$ (tela vegetal) .72

26 Diferença entre os valores de cor considerando somente os valores obtidos a partir do mês de março/1999, quando todos os tratamentos estavam instalados.

27 Diferença entre os valores de cor considerando todos os valores obtidos no experimento, excetuando-se o Tratamento D (tela vegetal). .73

28 Diferença entre os valores de condutividade elétrica considerando somente os valores obtidos a partir do mês de março/1999, quando todos os tratamentos estavam instalados.

29 Diferença entre os valores de condutividade elétrica considerando todos os valores obtidos no experimento, excetuando-se o Tratamento D (tela vegetal) 74

30 Diferença entre os valores de turbidez considerando somente os valores obtidos a partir do mês de março/1999, quando todos os tratamentos estavam instalados......75

31 Diferença entre os valores de turbidez considerando todos os valores obtidos no experimento, excetuando-se o Tratamento $\mathrm{D}$ (tela vegetal). 75

32 Diferença entre os valores de alcalinidade considerando somente os valores obtidos a partir do mês de março/1999, quando todos os tratamentos estavam instalados......76

33 Diferença entre os valores de alcalinidade considerando todos os valores obtidos no experimento, excetuando-se o Tratamento D (tela vegetal). 
34 Diferença entre os valores de $\mathrm{pH}$ considerando somente os valores obtidos a partir do mês de março/1999, quando todos os tratamentos estavam instalados.................77

35 Diferença entre os valores de $\mathrm{pH}$ considerando todos os valores obtidos no experimento, excetuando-se o Tratamento $D$ (tela vegetal)..................................77

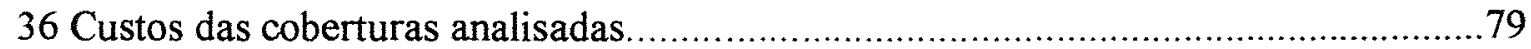




\section{AVALIAÇÃO DE DIFERENTES COBERTURAS DO SOLO NO CONTROLE DA EROSÃO EM TALUDES DE ESTRADAS FLORESTAIS}

Autora: CINTIA RODRIGUES DE SOUZA Orientador: Prof. FERNANDO SEIXAS

\section{RESUMO}

O objetivo deste trabalho foi avaliar técnica e economicamente três tipos de cobertura orgânica quanto à proteção de taludes de estradas rurais contra o processo erosivo e conseqüentes perda de solo e assoreamento dos cursos d' água. Os tratamentos empregados foram:

- Tratamento A: testemunha, solo descoberto;

- Tratamento B: colocação de placas de grama "Batatais" (Paspalum notatum Flügge);

- Tratamento C: cobertura do solo com casca de eucalipto picada (resíduo da indústria de celulose e papel);

- Tratamento D: cobertura do solo com tela de material orgânico impregnada com sementes de gramíneas (braquiária - Brachiaria decumbens Stapf e capim gordura Melinis minutiflora Beauv.) e leguminosas (feijão guandu - Cajamus cajan e soja perene - Neonotonia wightii). 
O estudo foi conduzido em um talude de estrada de $85 \%$ de declividade média, localizado no Município de Jacareí, Estado de São Paulo, em área da empresa

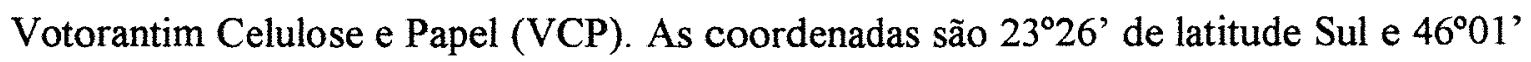
de longitude Oeste. A altitude média é de $720 \mathrm{~m}$.

As coletas de material foram feitas de acordo com a periodicidade das chuvas. Os parâmetros avaliados foram os seguintes: sólidos em suspensão, sedimentos pesados (aqueles depositados no fundo do recipiente de coleta), turbidez, cor, condutividade elétrica, $\mathrm{pH}$ e alcalinidade. Além disso, avaliou-se a taxa de cobertura das parcelas.

A quantidade total de sedimentos produzida na testemunha foi de $53,1 \mathrm{t} / \mathrm{ha}$, e $6,7 \mathrm{t} /$ ha a partir da sexta coleta, com todos os tratamentos instalados. Comparando as coberturas utilizadas a partir desta coleta, nota-se que a tela vegetal apresentou maior produção de sedimentos $(2,3 \mathrm{t} / \mathrm{ha})$, seguido pela grama (1,3 t/ha). Esta apresentou as maiores perdas de sedimento nos primeiros meses, quando ainda não estava cobrindo totalmente a área da parcela. A casca apresentou a menor perda de sedimentos $(0,4 \mathrm{t} / \mathrm{ha})$, reduzindo, em comparação à testemunha, a perda de sedimentos em $92,5 \%$, enquanto a grama e a tela vegetal reduziram em $69,3 \%$ e $54,1 \%$, respectivamente.

Economicamente, a cobertura mais dispendiosa é a tela $\left(\mathrm{R} \$ 4,00 / \mathrm{m}^{2}\right)$; a grama e a casca apresentaram valores próximos ( $R \$ 3,00 / \mathrm{m}^{2}$ e $R \$ 3,10 / \mathrm{m}^{2}$, respectivamente). Assim, a melhor cobertura do solo é a casca, já que seu custo está entre os mais baixos e proporcionou uma ótima redução na produção de sedimentos em taludes de estradas florestais. Porém, é de difícil instalação, especialmente em locais muito declivosos.

Os resultados obtidos neste trabalho, em taludes de estradas florestais, demonstram que coberturas orgânicas são eficientes para coibir a perda de solo por erosão. Isto reforça a necessidade de manutenção da casca e de outros resíduos no terreno, principalmente em locais declivosos e no caso de sistema de colheita com corte raso da floresta. 


\title{
EROSION CONTROL IN FOREST ROAD SLOPES BY ORGANIC COVERS
}

\author{
Author: CINTIA RODRIGUES DE SOUZA \\ Adviser: Prof. FERNANDO SEIXAS
}

\section{SUMMARY}

The objective of this research was to assess the effectiveness of three types of organic cover regarding to rural road slopes protection against the erosive process, trying to avoid soil loss and stream clog. The treatments analyzed were:

- Treatment A: bare ground (control);

- Treatment B: "Batatais" grass (Paspalum notatum Flügge);

- Treatment C: chopped Eucalyptus bark (residue of paper and pulp industry);

- Treatment D: organic mat with seeds of Brachiaria decumbens Stapf, Melinis minutiflora Beauv., Cajanus cajan and Neonotonia wightii.

The study site was located in a slope with 85 percent of gradient, in Municipality of Jacarei, State of São Paulo, in a Votorantim Celulose e Papel (VCP) area. The coordinates are $23^{\circ} 26^{\prime} \mathrm{S}$ and $46^{\circ} 01^{\prime} \mathrm{W}$, with an average altitude of $720 \mathrm{~m}$. 
The material collection was made according to the rain distribution. The parameters analyzed were the following: suspension solids, heavy solids, turbidity, color, electrical conductivity, $\mathrm{pH}$ and alkalinity. Besides, the plots cover taxes were evaluated too.

The total quantity of sediments produced in the control plot was 53,1 tha, and $6,7 \mathrm{t} / \mathrm{ha}$ after the sixth material collection, when all the treatments were applied. Among the three covers since that material collection, it's possible to notice that the organic mat presented the highest sediment loss $(2,3 \mathrm{t} / \mathrm{ha})$, followed by the grass cover $(1,3 \mathrm{t} / \mathrm{ha})$. The grass presented the higher sediment production in the beginning of the experiment, when the grass wasn't covering the whole plot area. The chopped Eucalyptus bark produced the lower sediment waste $(0,4 \mathrm{t} / \mathrm{ha})$. Compared to the control treatment, the chopped Eucalyptus bark did give a 92,5 percent reduction in sediment production, while the grass and the organic mat reduced it in 69,3 percent and 54,1 percent, respectively.

The most expensive cover was the organic mat $\left(\mathrm{R} \$ 4,00 / \mathrm{m}^{2}\right)$; the grass and the chopped Eucalyptus bark presented close values (RS $3,00 / \mathrm{m}^{2}$ and $\mathrm{R} \$ 3,10 / \mathrm{m}^{2}$, respectively). In such case, the best soil cover is the chopped Eucalyptus bark, because its cost is one of the lowest and produced the lower sediment waste in forest road slopes. However, its installation is difficult, specially in higher gradients.

The results obtained in this work, in forest road slopes, show that organic cover is efficient in reducing the soil losses by erosion. This reinforces the necessity of bark and other residues maintenance on the ground, mainly in high gradients and in case of harvest system with clear cut. 


\section{INTRODUÇÃO}

O Estado de São Paulo perde anualmente 194 milhões de toneladas de solos férteis devido à erosão. Deste montante, aproximadamente 40 milhões de toneladas vão para o fundo de rios e lagos, causando sérios danos ao meio ambiente. Este valor representa uma perda de 20 centímetros de solo em uma área de 100.000 ha, contabilizando cerca de US\$200 milhões em termos de nutrientes (São Paulo, 1995).

A erosão é influenciada pela precipitação, tipo de solo, topografia, cobertura vegetal e práticas de manejo e conservação do solo, e pode causar os seguintes danos: perda de solo, sedimentação dos cursos d'água, poluição e degradação da qualidade da água da microbacia, degradação visual, obstrução da cama de desova de peixes, diminuição da vida útil de reservatórios e perda da capacidade de produção da floresta, devido à perda de nutrientes, principalmente nitrogênio, fósforo e potássio, prejudicando as rotações futuras caso os elementos retirados não sejam repostos (Grace III et al., 1996; Vital, 1996; Robichaud et al., 1991; Machado \& Souza, 1990; FAO, 1989; Grey, 1988; Megahan, 1977; Kidd \& Megahan, 1972).

A rede viária possibilita o acesso às áreas florestais, viabilizando a implantação, a manutenção e a proteção da floresta e permitindo a colheita e o transporte de madeira. No Brasil predomina o transporte rodoviário como via de acesso aos plantios florestais, apesar da existência de ferrovias e hidrovias. Isto mostra a importância dos trabalhos de conservação das estradas, que são as principais causadoras de erosão e sedimentação nas regiões florestais brasileiras. Estima-se que mais de $90 \%$ da produção de sedimentos em florestas seja proveniente da construção e manutenção de estradas para exploração e 
baldeio de toras (Grace III et al., 1996; Neary \& Hornbeck, 1994; Duarte \& Berger, 1988).

Da erosão que ocorre nas estradas, aproximadamente $75 \%$ são provenientes dos taludes de aterro e corte. Assim, o enfoque deste trabalho é o controle da erosão em taludes de estradas florestais. Uma das mais importantes medidas de controle da erosão superficial nestes locais é a aplicação de coberturas que impeçam mecanicamente a perda de solo, como palha, cavacos de madeira, cascalho, plantio de sementes, ou o "mulch", constituído por uma camada de material orgânico que pode conter sementes de gramíneas e leguminosas. Deve-se ressaltar que quanto mais declivoso for o local, menor é a eficiência do tratamento.

O presente trabalho avaliou a eficiência de três coberturas do solo no controle da erosão em um talude de estrada na Votorantim Celulose e Papel, no município de Jacareí - SP, no Vale do Paraíba. A evolução do uso do solo nesta região abrangeu a transformação da cobertura original na cultura de cana-de-açúcar e, posteriormente, na de café. Com a crise na cultura cafeeira, a atividade agrária migrou para a pecuária leiteira, que não prosperou devido à topografia acidentada da região, causando uma diminuição da capacidade natural de suporte do solo, devido à erosão, à exaustão da fertilidade do solo e à degradação de microbacias. Atualmente, o reflorestamento com eucalipto é uma atividade de destaque no Vale do Paraiba, principalmente para atender à demanda industrial de madeira para a produção de papel e celulose.

As hipóteses a serem testadas são as seguintes:

a) a aplicação de coberturas orgânicas nos taludes das estradas florestais reduz a erosão;

b) as três coberturas orgânicas dos taludes diferem quanto à eficiência e ao custo;

c) a tela vegetal impregnada com sementes de gramíneas e leguminosas proporciona uma maior redução na produção de sedimentos nos taludes;

d) a tela vegetal é a cobertura de maior custo. 
O objetivo deste trabalho foi a avaliação técnica e econômica de alternativas de coberturas orgânicas para a proteção de taludes de estradas em áreas rurais, visando a proteção destes pavimentos e a diminuição do processo erosivo, que causa a perda de solo e, como conseqüência, o assoreamento dos cursos d'água.

Os objetivos especificos foram os seguintes:

a) avaliar três tipos de cobertura orgânica - grama "Batatais", casca de Eucalyptus spp. picada e tela vegetal impregnada com sementes de gramineas e leguminosas - instaladas em um talude de estrada florestal, quanto à produção de sedimentos e escoamento superficial;

b) avaliar a evolução da taxa de cobertura dos tratamentos empregados;

c) determinar qual das coberturas é mais vantajosa economicamente;

d) definir, através de critérios técnicos e econômicos, qual a melhor cobertura para coibir a erosão em taludes de estradas florestais. 


\section{REVISÃO DE LITERATURA}

\subsection{Causas e Efeitos da Erosão}

Erosão é o processo de desprendimento, remoção e transporte de partículas de solo pela ação da água, vento e gravidade (Grey, 1988; Astete, 1985). A erosão hídrica é devida somente à ação da água (Ormachea \& Llerena, 1992), e geralmente inicia-se com o impacto das gotas de chuva, dispersando os agregados do solo. Quando a quantidade de chuva torna-se maior do que a quantidade de água que infiltra-se no solo, a água que escorre no sentido da pendente é denominada escoamento superficial.

A erosão hidrica resulta das interações entre a água da chuva e o solo, que são denominadas erosividade e erodibilidade, respectivamente. A erosividade é definida como a capacidade potencial da chuva de causar erosão e depende das suas características fisicas. A erodibilidade é definida como a susceptibilidade do solo à erosão, em função de suas características internas, como textura, estrutura, porosidade e permeabilidade, e externas, como cobertura vegetal existente, uso do solo, topografia e relevo. Devido à erosividade e à erodibilidade, a severidade da erosão varia bastante no tempo e no espaço (Ormachea \& Llerena, 1992; Durán, 1992; Grey, 1988).

A erosão é relacionada, entre outros fatores, a:

a) fatores fisicos: tipo de solo, precipitação, escoamento superficial, ocorrência de ventos, topografia, cobertura vegetal e práticas de manejo e conservação do solo. Grey (1988) afirma que na escala macro, o clima e a geologia são os fatores que 
controlam a erosão. Em uma escala regional, a topografia e a cobertura vegetal exercem maior influência;

b) densidade das estradas: é o comprimento total de estradas por unidade de área da bacia. As taxas de erosão estão diretamente relacionadas ao comprimento total de estradas em uma bacia. Uma rede de estradas de aproximadamente 30 a $40 \mathrm{~m} / \mathrm{ha}$ é considerada ótima para a maior parte dos propósitos do manejo;

c) locação de estradas: este fator, relacionado à declividade, cursos d'água e solos, tem um efeito direto na quantidade de sedimento que alcança os rios;

d) padrão de estradas e construção: a largura da estrada, declividade de cortes ou aterros, métodos de construção e instalações de drenagem afetam diretamente a área de distúrbio e os danos potenciais das estradas florestais (Ranzini, 1990; FAO, 1989; Astete, 1985; Patric \& Brink, 1977).

De acordo com Grey (1988), os seguintes fatores são comumente usados como indicadores da ocorrência da erosão:
a) acúmulo superficial de serapilheira e material orgânico;
b) concentração anormal de pedras na superficie;
c) movimentação e acúmulo de solo em plantas ou rochas;
d) formação de sulcos ou canais.

As causas da erosão são as seguintes:

- causas físicas:
a) taludes com declividade entre 70 e $100 \%$;
b) interceptação do fluxo subsuperficial pelos taludes de corte das estradas;
c) fortes pendentes longitudinais do leito dos rios;
d) precipitações de alta intensidade e elevado conteúdo de umidade relativa, que contribuem para os altos conteúdos de água no solo;
e) ação do escoamento superficial;
i) concentração e interceptação de água;
f) diminuição das taxas de infiltração em partes da estrada; 
g) água de infiltração que ajuda a saturar os solos, aumentando seu peso e acelerando os deslizamentos;

h) diminuição da força de corte ou aumento da tensão de corte, ou ambos, em cortes e aterros.

- causas antrópicas:

a) remoção ou redução da vegetação natural, deixando grandes extensões de solo exposto;

b) exploração agropecuária sem o uso de práticas conservacionistas;

c) aumento nos gradientes de declividade pela construção de cortes e aterros;

d) destruição ou deterioração da estrutura e fertilidade do solo;

e) construção de estradas florestais (FAO, 1989; Soto, 1987).

Segundo FAO (1989), o reconhecimento do tipo de erosão que ocorre no local e os procedimentos para seu controle são importantes para evitar áreas problemáticas. A erosão pode ser caracterizada como laminar (erosão por desagregação e salpicamento do solo) ou em sulcos. Sorrenson \& Montoya (1989) citam, além destes tipos, a erosão em voçorocas. A forma mais comum é a laminar, que ocorre em terrenos em declive durante chuvas de alta intensidade, quando o solo está descoberto e sua capacidade de absorção de água está limitada. Apesar de no início ser pouco perceptível aos olhos do agricultor, essa forma de erosão causa danos consideráveis às terras cultivadas. As erosões em sulcos e voçorocas, com profundidades e larguras variáveis, ocorrem em áreas localizadas, pela concentração do fluxo de enxurradas. As voçorocas ocorrem principalmente ao longo das rodovias, onde altos fluxos de água ficam concentrados.

De acordo com Sequera (1989), pode-se classificar a erosão a partir da perda anual de solo em $\mathrm{t} / \mathrm{ha}$. Isso pode ser visualizado na Tabela 1. 
Tabela 1. Classes de erosão de acordo com a perda de solo.

\begin{tabular}{cc}
\hline Perda de solo (t/ha/ano) & Classe de erosão \\
\hline$<10$ & Nula \\
$10-50$ & Moderada \\
$50-200$ & Alta \\
$>200$ & Muito alta \\
\hline
\end{tabular}

Fonte: Sequera (1989)

Os danos causados pela erosão são bastante conhecidos, sendo citados por diversos autores. Os principais são: perda de solo, sedimentação dos cursos d'água, aumento do deflúvio, poluição e degradação da qualidade da água da microbacia (devido ao assoreamento de rios, aumento das temperaturas e diminuição dos níveis de oxigênio, chegando até a causar mudanças no ecossistema aquático), destruição de pontes, degradação visual, obstrução da cama de desova de peixes, diminuição da vida útil de reservatórios e perda da capacidade de produção da floresta, devido à exportação de nutrientes do sítio (principalmente nitrogênio, fósforo e potássio), prejudicando as rotações futuras caso os elementos retirados não sejam repostos (Grace III et al., 1996; Vital, 1996; Robichaud et al., 1991; Machado \& Souza, 1990; FAO, 1989; Grey, 1988; Megahan, 1977; Kidd \& Megahan, 1972).

Rose (1993) divide os problemas associados com erosão do solo e sedimentação em "on-site" e "off-site". Tipicamente, os problemas "on-site" são associados com perda de sedimentos, e os problemas "off-site", com ganho de sedimentos (pelo menos temporariamente). Os danos "on-site" são mais difundidos em áreas rurais onde a sustentabilidade pode ser ameaçada, enquanto o foco dos problemas "off-site" diz respeito ao prejuizo a estradas, rios e represas. Danos "off-site" são de mais fácil identificação que os danos "on-site" e os custos econômicos e sociais associados com os danos "off-site" são comumente mais fáceis de identificar e quantificar. 


\subsection{Erosão nas Estradas Florestais}

As estradas florestais, assim como os outros tipos de estrada, são obras de engenharia. Elas são constituídas por duas partes: subgreide e pavimento (FAO, 1977). O subgreide é formado por solo que ocorre naturalmente na estrada ou próximo dela. Nas seções de corte, a metade inferior normalmente consiste de solo não perturbado, e a metade superior, de solo transferido do lado cortado da estrada e compactado. Nas seções de aterro, o subgreide é construído com solo transportado de cortes ou de outro local disponivel.

O termo pavimento é comumente usado para designar a camada de concreto ou asfalto da estrada. Entretanto, pode-se considerar pavimento qualquer material colocado na estrada acima do subgreide e que consiste de três camadas: a superfície, a base e a sub-base. Quanto maiores forem estas camadas, maior será a capacidade de suporte da estrada. Porém, em muitas estradas florestais somente uma camada de cascalho é colocada, fazendo o papel das três necessárias.

As estradas florestais são geralmente formadas por material rochoso natural de composição granular sem aglutinantes, por ser este o método de construção mais econômico e que satisfaz as necessidades das empresas. Entretanto, é sensivel aos danos causados por uso intenso e condições climáticas (Dietz et al., 1983).

De acordo com Kidd \& Patric (1981), o principal uso das estradas em florestas é fazer o escoamento da produção madeireira, implicando em tráfego predominante de caminhões e outros veículos pesados, exigindo completo acesso à área de corte. FAO (1989) e Adamovich (1971) citam que, além de permitirem o transporte de pessoas e produtos, as estradas são necessárias ao manejo florestal, à silvicultura e à proteção contra o fogo. 
De acordo com Machado (1989), a rede rodoviária existente nas florestas implantadas brasileiras ultrapassava os $600 \mathrm{mil} \mathrm{km}$ de extensão (para 6,6 milhões de hectares reflorestados), sendo a maior parte de baixo padrão construtivo, devido principalmente à falta de planejamento, ao baixo investimento nesse setor e à aplicação inadequada dos recursos disponíveis. Refinamentos tais como pavimentação, estruturas de drenagem e manutenções periódicas são geralmente mínimos (Kidd \& Patric, 1981).

De acordo com Seixas (1988), boas estradas permitem manutenção mais barata e podem ser mais facilmente mantidas em condições de uso permanente. Além disso, produzem menos danos ao solo, à qualidade da água e à paisagem, e podem economizar recursos de várias formas. Os custos de colheita, por exemplo, são bastante afetados pela locação e qualidade das estradas. Duarte \& Berger (1988) ressaltam que o custo de transporte, incluindo os custos de construção e manutenção de estradas, representa de 30 a $50 \%$ do custo da madeira que chega ao consumidor.

$\mathrm{Na}$ construção de uma estrada é muito importante a existência de um projeto de proteção contra a erosão, que deve conter as seguintes medidas:

a) coleta e orientação da água da chuva: feitas a fim de minimizar os efeitos da erosão através da abertura de valas, sarjetas, canais, correção das curvas e taludes da estrada, revestimento vegetal, etc.;

b) trabalhos corretivos e levantamentos de causa e efeito de sulcos de máquinas de construção ou outros veículos, trilhas de animais, caminhos velhos, e outros fatores que possam contribuir com o problema da erosão;

c) caixas de empréstimo: são muitas vezes agravantes da erosão porque sua drenagem é deficiente ou inexistente;

d) voçorocas: deve-se corrigir e prevenir a formação das voçorocas por meio de restauração da superficie do solo e reconstituição da cobertura vegetal;

e) revestimento dos taludes de corte e aterro: geralmente feita com gramíneas ou mesmo vegetação de maior porte (Setor de Conservação de Estradas da Klabin Agro-florestal, 1985). 
A locação de estradas deve ser realizada com o máximo cuidado, da seguinte maneira:

a) em primeiro lugar, revisar os planos de manejo e corte a fim de determinar as áreas que devem ser servidas primeiro e qual a direção geral que as estradas devem tomar; b) checar as especificações requeridas: raio mínimo de curvatura, greides máximos, tipo de equipamento de transporte, peso das cargas a serem carregadas, velocidade dos veículos, etc.;

c) no escritório, escolher um alinhamento usando fotografias aéreas e mapas topográficos e geológicos, classificação de uso da terra e dados do solo que estiverem disponíveis;

d) checar a rota para alinhamento, greides e curvas, condições do solo, drenagem de água, correntes d'água, disponibilidade de cascalho e outros materiais (FAO, 1977).

Segundo Dietz et al. (1983), os aspectos técnicos do tráfego sugerem um declive longitudinal regular e equilibrado, sendo que o recomendável varia entre 2 e $8 \%$. No caso de declives longitudinais superiores a $8-10 \%$, as estradas se tornam fortemente sujeitas à erosão, embora em estradas planas dificilmente a drenagem seja constante e suficiente. Para que a superficie da estrada seja suficientemente drenada, é recomendado um perfil de cobertura que apresente uma elevação de $10 \mathrm{~cm}$ na linha central com um declive transversal de aproximadamente $5 \%$ para ambos os lados. As estradas florestais devem ser adaptadas o máximo possível ao terreno, devido a questões ecológicas (diminuição do impacto ambiental) e econômicas (redução dos custos).

A FAO (1977) sugere ainda que os declives e as curvas sejam mínimos. Locar estradas em terrenos planos ou ondulados normalmente não apresenta dificuldades, mas em terrenos montanhosos esta tarefa é extremamente dificil.

De acordo com FAO (1977), os custos de construção de estradas variam pouco, sendo normalmente de $75-80 \%$ do custo total para o equipamento, $10-15 \%$ para a mãode-obra e 5-10\% para o material empregado. São dificeis de estimar devido à variedade 
de terreno, solos, máquinas utilizadas, características de desenho e outros fatores (Layton et al., 1992). Segundo Carter et al. (1973), isto é função dos seguintes fatores:

a) custo do equipamento a ser utilizado;

b) taxa de produção do equipamento, que depende de:

$\rightarrow$ declividade do local;

$\rightarrow$ porcentagem de rocha na escavação.

c) quantidade de estradas requeridas, que é função de:

$\rightarrow$ extensão da estrada;

$\rightarrow$ largura da estrada.

A construção e o uso de estradas florestais provocam mudanças na paisagem. De todos os tipos de atividades silviculturais, a construção imprópria e a manutenção inadequada de estradas são as principais causas antrópicas de erosão e sedimentação, além da colheita e do preparo de solo (Grace III et al., 1996; Lima, 1996; Neary \& Hornbeck, 1994; Machado \& Souza, 1990; Seixas, 1988; Askey \& Williams, 1984; Yoho, 1980; Patric \& Brink, 1977; Kidd \& Megahan, 1972). Bonell (1991) afirma que a importância das estradas como fonte de erosão durante as atividades florestais tem sido amplamente estudada nos Estados Unidos.

Grace III et al. (1996) e Neary \& Hornbeck (1994) estimam que mais de $90 \%$ da produção de sedimentos em florestas são provenientes da construção e manutenção de estradas para exploração e baldeio de toras.

É evidente que os distúrbios que criam grandes áreas de solo descoberto, agravados por chuvas, solos erosivos e terrenos declivosos aumentam a produção de sedimentos. A construção de estradas agrava a taxa de erosão, a perda de solo e o número médio de processos erosivos (Neary \& Hornbeck, 1994). Hewlett \& Doss (1984) recomendam que no manejo da floresta tenha-se um controle cuidadoso sobre práticas que exponham a superficie do solo à energia da chuva e do escoamento superficial, como a construção de estradas, pois quando o solo está descoberto, 
intensidades normais de chuva são suficientes para desprender, transportar e depositar produtos da erosão nas regiões de menor altitude, e, se o solo estiver solto, um pequeno escoamento pode arrastar uma grande quantidade de solo.

De acordo com Megahan (1977), a construção das estradas florestais é uma grande causadora de erosão, pelos seguintes motivos:
a) remoção ou redução da cobertura vegetal;
b) danos à estrutura e fertilidade do solo;
c) aumento dos gradientes de declividade devido à construção de cortes e aterros;
d) diminuição da taxa de infiltração em partes da estrada;
e) interceptação do fluxo subsuperficial pelo corte da estrada;
f) diminuição da força de corte, aumento da tensão de corte, ou ambos, nos taludes de corte e aterro;
g) concentração de água gerada e interceptada.

Segundo Burroughs \& King (1989), há uma divisão da produção total de sedimentos nas estradas em aproximadamente $60 \%$ provenientes dos aterros, $25 \%$ dos leitos e $15 \%$ dos cortes e laterais.

A produção de sedimentos durante o primeiro ano após a construção da estrada é muito alta, já que o material não está consolidado, decrescendo rapidamente com o tempo (Burroughs \& King, 1989; Kidd \& Megahan, 1972). Machado \& Souza (1990) confirmam que os maiores danos são causados durante ou logo após a exploração florestal e a construção de estradas, quando os solos estão expostos à erosão.

Experiências realizadas por Tuchy (1982), citado por Machado \& Souza (1990), mostram que o índice de erosão antes da abertura de uma estrada florestal era de $30 \mathrm{~kg} / \mathrm{ha} / \mathrm{ano}$, subindo durante a abertura para $3.000 \mathrm{~kg} / \mathrm{ha} / \mathrm{ano}$. Algum tempo após o término da construção da estrada florestal, o índice de erosão baixou para $120 \mathrm{~kg} / \mathrm{ha} / \mathrm{ano}$. $\mathrm{O}$ índice de erosão durante a construção da estrada aumentou 100 vezes em relação à 
fase anterior à construção, indicando que deve haver um rigoroso controle durante e após a execução do projeto de estradas florestais.

De acordo com Machado \& Souza (1990), a erosão nas áreas de exploração é menor do que nas estradas florestais, já que os distúrbios ao solo e a sua exposição às intempéries são também menores. Neary \& Hornbeck (1994) afirmam que somente a colheita florestal pode aumentar a taxa natural de erosão em 4 vezes, enquanto a construção de estradas na área de exploração pode elevar esta taxa em aproximadamente 120 vezes, mesmo em áreas declivosas não perturbadas. A erosão provocada pela colheita florestal e implantação e utilização de estradas florestais produz um enorme impacto nos recursos naturais e pode causar sérios prejuízos econômicos, sendo proveniente principalmente da faixa de solo terraplenada. Disso confirma-se que as estradas possuem o efeito mais impactante no processo de colheita florestal.

Oliveira (1997) e FAO (1989) afirmam que para minimizar os impactos da construção de estradas deve-se reduzir a densidade das estradas ao mínimo indispensável, utilizar as características naturais do terreno, como divisores de águas e gradientes baixos para minimizar a área perturbada, evitar locais com solos úmidos e propensos à erosão. Além disso, é necessário revestir com gramíneas ou arbustos as laterais ao longo das estradas, manter as vias em áreas planas, evitar os taludes longos, declivosos e instáveis, que ocasionam maior taxa de erosão e elevam os custos de manutenção, e locar estradas em solos bem drenados e longe dos cursos d'água.

De acordo com Santos (1985), a principal causa da erosão em estradas florestais é a falta ou deficiência de um sistema de drenagem adequado. O problema surge na forma de sulcos e buracos onde os solos têm baixa resistência à erosão, e, sob a ação de enxurradas, evoluem para grandes ravinamentos, tendo como conseqüência perda de material da superficie da estrada (Kantola \& Harstela, 1988). Segundo Machado \& Souza (1990), o principal fundamento de uma rede de drenagem é que ela deve interceptar, coletar e remover as águas de escoamento superficial e subsuperficial das 
estradas florestais. A maioria dos problemas de drenagem pode ser controlada se forem evitados pontos topográficos e geológicos críticos, tais como: solo siltoso, curva vertical côncava, locais de infiltração natural de água, nascentes, etc. O sistema de drenagem deve sempre ser mantido sem obstruções (FAO, 1989).

Para a adequada conservação das estradas florestais deve-se observar um limite máximo de velocidade, que garanta a segurança no trânsito e evite um alto desgaste da pista de rolamento. Além disso, para elevar a segurança e evitar danos, recomenda-se uma limitação no uso de acordo com as condições climáticas. Isto é válido para regiões sujeitas a geadas, especialmente no período de descongelamento, nas florestas tropicais, onde as precipitações são intensas, e, no caso dos países temperados, onde há ocorrência de neve (Seixas, 1988; FAO, 1977). É importante a realização de constantes manutenções nas estradas florestais e aceiros, nos sentidos transversal e longitudinal, como forma de minimizar os impactos causados aos cursos d'água decorrentes da erosão (Vital, 1996; Kantola \& Harstela, 1988; Dietz et al., 1983).

A manutenção da estrada consiste normalmente em remover irregularidades da superficie da estrada, além de outras operações que devem ser realizadas em intervalos regulares, como limpeza dos canais de drenagem, reaplicação de cascalho e limpeza das bordas para aumentar o ângulo de visão (FAO, 1977).

De acordo com FAO (1989), a manutenção de estradas é essencial para: (1) preservar as condições de construção da estrada; (2) proteger recursos adjacentes e seu uso seguro e (3) prover tráfego eficiente. Infelizmente, a manutenção freqüentemente é negligenciada ou realizada inapropriadamente, resultando em uma rápida deterioração da estrada.

O custo da manutenção depende do padrão de construção da estrada, do peso dos veículos que nela trafegam, da densidade de tráfego e das condições climáticas. Conseqüentemente, é dificil de ser estimado. Em regiões montanhosas, o custo de 
manutenção pode representar $10 \%$ do custo de construção da estrada, até que ela esteja estabilizada (FAO, 1977).

Duarte \& Berger (1988) analisaram estradas florestais de diferentes padrões e concluíram que quanto melhor o estado de conservação do leito das estradas, menor será o custo operacional dos veículos e conseqüentemente do transporte de madeira, sendo os custos do transporte excessivamente elevados quando utilizam-se estradas de baixo padrão.

\subsection{Implicações na qualidade da água e na perda de nutrientes}

Souza et al. (1991) citam os principais fatores ambientais que podem ser afetados pela construção de estradas e exploração florestal:

a) aspectos hidrológicos: a qualidade e a vazão dos cursos d'água podem ser afetadas pelas atividades de exploração florestal, dependendo do método de manejo adotado, da capacidade de armazenamento de água no solo, da intensidade de distúrbios causados pelo sistema de exploração e do tamanho da área explorada;

b) solo: os danos são provenientes da erosão que ocorre com a remoção da cobertura orgânica e a exposição das diferentes camadas de solo. As estradas e alguns métodos de extração, como o arraste, constituem as principais causas de danos ao solo. Nas estradas, o processo de erosão do solo exposto se inicia pela terraplenagem e continua nos taludes de corte e aterro, nas sarjetas e nas pistas. Estradas mal drenadas acumulam água que pode ser fonte de enxurradas, causando erosão. Os maiores riscos de danos ocorrem em terrenos acidentados, em solos naturalmente erodíveis e instáveis, passíveis de deslizamentos de terra. A exploração de florestas ou a localização de estradas em terrenos instáveis aumentam os riscos de deslizamentos.

c) fauna, flora, recreação e recursos paisagísticos;

d) qualidade da água: as causas primárias de danos aos cursos d'água são mudanças de regime hídrico, sedimentação e turbidez, devido à erosão excessiva das áreas exploradas, a estradas mal localizadas e a áreas com distúrbios do solo. 
A qualidade da água afeta diretamente o habitat da fauna aquática. As principais conseqüências da má qualidade da água são a redução no tamanho da população e da saúde dos peixes, principalmente em rios e córregos de baixo volume de água.

Os sedimentos em suspensão são partículas usualmente inorgânicas liberadas de seu substrato pelo impacto da gota da chuva, da gravidade e fluxos superficiais e carregados pelo escoamento superficial, que possuem significados físico, químico e biológico. A presença física de sedimentos afeta características da água como turbidez, sabor e odor, prejudicando os valores estéticos e recreacionais dos cursos d'água. A composição química dos sedimentos é próxima à do solo, mas geralmente contém maior quantidade de silte, argila e matéria orgânica. Quanto ao aspecto biológico dos sedimentos, estes podem afetar o ecossistema aquático diretamente pela sua presença e indiretamente pelas interações físicas e químicas com o ambiente. Os sedimentos reduzem a capacidade dos peixes encontrarem alimento, reduzem a profundidade do curso d'água, inibem a fotossíntese e podem diminuir o nível de oxigênio dissolvido (Chang, 1982; Hewlett, 1982), além de aumentarem o custo de tratamento da água para abastecimento da população e causar danos a equipamentos como turbinas, bombas e materiais de irrigação. A deposição de sedimentos em rios e estuários aumenta a necessidade de dragagens, a fim de evitar problemas para sistemas de transporte hidroviário e para as usinas hidrelétricas. Cassels et al. (1985) afirmam que o manejo de bacias hidrográficas pode substancialmente reduzir os niveis de sedimentação associados ao corte de florestas.

A turbidez na água é causada pela presença de material em suspensão, como sedimentos orgânicos ou inorgânicos. É uma medida de uma propriedade ótica da amostra, assim, não deve-se correlacionar os valores de turbidez com a concentração de sedimentos, uma vez que a forma, tamanho, índice de refração, etc., das partículas são importantes do ponto de vista ótico, porém, guardam pouca relação com a concentração e a massa especifica da matéria em suspensão na amostra (Lima, 1996; American Public 
Health Association, 1976). Um alto nível de turbidez da água prejudica a beleza dos rios e dos lagos, com conseqüentes prejuízos para o turismo ou recreação.

$\mathrm{O}$ aspecto mais importante em relação à qualidade da água é a sedimentação. De acordo com Chang (1982) e Hewlett (1982), sedimentos em suspensão são partículas usualmente inorgânicas, liberadas do substrato pelo impacto da gota da chuva, da gravidade e de fluxos superficiais, e carregados pelo escoamento superficial. Chang (1982) estima que mais de 4 bilhões de toneladas de sedimentos atinjam cursos d' água nos Estados Unidos todos os anos (valor 500 a 700 vezes maior do que a taxa natural), sendo considerado o principal poluente de águas do país.

Para Yoho (1980), é importante diferenciar material erodido de sedimento. O primeiro é aquele depositado nas partes mais baixas dos taludes antes de atingir os cursos d'água. O solo erodido torna-se sedimento quando atinge o curso d' água, causando impacto na qualidade da água, pois altera a concentração de sedimentos.

De acordo com Neary \& Hornbeck (1994), a produção de sedimentos depende das condições climáticas, hidrologia, geologia, solos, vegetação e uso do solo para cada bacia hidrográfica. As taxas naturais de sedimentação em áreas florestadas é considerada baixa ( $<100 \mathrm{~kg} / \mathrm{ha} / \mathrm{ano})$, inclusive menores do que as taxas geológicas, não constituindo um problema importante nos ecossistemas florestais não perturbados. A erosão em florestas não perturbadas é menor do que $0,27 \mathrm{t} / \mathrm{ha} / \mathrm{ano}$, inferior à taxa normal de erosão geológica, que é de 0,49 a 0,82 t/ha/ano (Beasley, 1979; Patric, 1976; Smith \& Stanley, 1965, citados por Grace III et al., 1996; Yoho, 1980).

De acordo com Grace III et al. (1996), os níveis inaceitáveis de erosão ocorrem quando o solo e a cobertura da floresta são perturbados pelas atividades florestais, podendo aumentar em até 5 vezes as taxas naturais de erosão. Segundo Neary \& Hornbeck (1994), a produção de sedimentos de sistemas de rios principais pode variar desde $1.200 \mathrm{~kg} / \mathrm{ha} / \mathrm{ano}$ (Columbia, EUA) até $140.000 \mathrm{~kg} / \mathrm{ha} / \mathrm{ano}$ (Huang Ho, China). 
A Tabela 2 mostra os valores toleráveis de turbidez em diferentes usos da água.

Tabela 2. Turbidez tolerável para diferentes usos da água.

\begin{tabular}{cc}
\hline Uso da água & Turbidez tolerável $(\mathrm{mg} / \mathrm{l})$ \\
\hline Beber & 5 \\
Indústria de papel & 5 \\
Indústria têxtil & 5 \\
Nadar & 10 \\
\hline
\end{tabular}

Fonte: Chang (1982)

Há diversos dados relacionando a construção de estradas à erosão e à sedimentação. Segundo Grace III et al. (1996), a construção de estradas pode aumentar a produção de sedimentos de 2 a 150 vezes, comparando com a produção em bacias não perturbadas durante o primeiro ano de análise. Kidd \& Megahan (1972) determinaram que a produção de sedimentos decorrente da erosão superficial teve um acréscimo de aproximadamente 220 vezes, após a construção de estradas em solos declivosos altamente erodíveis em Idaho Batholith, área localizada no oeste dos Estados Unidos.

Estes autores afirmam que a erosão nas estradas decresce rapidamente com o tempo depois de taxas iniciais extremamente altas, porque o material mais erodivel foi removido e a vegetação e a serapilheira tendem a se acumular no local. Deve-se ressaltar que após 3 anos a produção de sedimentos nas áreas de estradas ainda estava $50 \%$ maior do que nas áreas não perturbadas. A produção média anual de sedimentos nas estradas permite avaliar a tendência no tempo, como pode-se notar na Tabela 3. 
Tabela 3. Produção de sedimentos devido à erosão superficial em estradas por número de anos após a construção.

\begin{tabular}{cccc}
\hline $\begin{array}{c}\mathrm{N}^{0} \text { de anos após a } \\
\text { construção da estrada }\end{array}$ & $\begin{array}{c}\text { Produção de sedimentos } \\
\left(\mathrm{m}^{3}\right)\end{array}$ & $\begin{array}{c}\% \text { do total } \\
\% \text { acumulado }\end{array}$ \\
\hline 1 & 57,3 & 83,8 & 83,8 \\
2 & 6,4 & 9,4 & 93,2 \\
3 & 0,4 & 0,6 & 93,8 \\
4 & 1,5 & 2,2 & 96,0 \\
5 & 1,6 & 2,3 & 98,3 \\
6 & 1,2 & 1,7 & 100,0 \\
\hline Total & 68,4 & 100,0 & \\
\hline
\end{tabular}

Fonte: Kidd \& Megahan (1972)

Gonsoir \& Gardner (1971) conduziram um estudo em Idaho Batholith, onde a produção de sedimentos após a construção da estrada foi até 1000 vezes maior do que as taxas naturais de erosão em áreas não perturbadas.

Thangtham \& Pransucharit (1983), citados por Henderson \& Witthawatchutikul (1984), relataram um aumento médio anual de $290 \%$ nos sedimentos suspensos no Rio Mae Taeng, na Tailândia, durante 10 anos de construção de estradas e redução da cobertura florestal. Kraayenhagen (1981), também citado pelos autores, mediu os sedimentos pesados provenientes de uma estrada florestal em Mae Sa, no norte da Tailândia, em 4,96 t/ha, contra 0,0013 t/ha em áreas cultivadas. Henderson \& Witthawatchutikul (1984), em um estudo conduzido em uma microbacia florestada no leste da Tailândia, concluíram que foi produzido um total de $6.904 \mathrm{~m}^{3}$ de sedimentos no primeiro ano de construção de uma estrada com $3 \mathrm{~km}$ de extensão, ou $10.494 \mathrm{t} / \mathrm{km}^{2}$ de área da bacia. A maior parte dos sedimentos produzidos pôde ser atribuída à erosão proveniente das estradas. 
Rose (1993) afirma que quando a escala de estudo é aumentada do talude para a bacia hidrográfica, a dificuldade de mensuração dos fluxos de sedimentos cresce substancialmente. Vital (1996) analisou a produção de sedimentos em suspensão em duas microbacias, sendo que na primeira foi realizado o corte raso de Eucalyptus saligna aos 7 anos de idade e a segunda foi mantida intacta. Os resultados obtidos para a primeira microbacia encontram-se na Tabela 4.

Tabela 4. Valores dos parâmetros físicos e químicos observados antes e após o corte da floresta.

\begin{tabular}{lccccc}
\hline & $\begin{array}{c}\text { Cor } \\
\text { (ptCo) }\end{array}$ & $\begin{array}{c}\text { Turbidez } \\
\text { (FTU) }\end{array}$ & $\mathrm{pH}$ & $\begin{array}{c}\text { Sedimentos em } \\
\text { suspensão }^{1} \\
(\mathrm{Kg} / \mathrm{ha} / \mathrm{ano})\end{array}$ & $\begin{array}{c}\text { Condutiv. elétrica } \\
\text { (umho/cm) }\end{array}$ \\
\hline Antes do corte & 83 & 7,0 & 6,1 & 19,8 & 80 \\
Após o corte & 147 & 9,3 & 6,1 & 41,5 & 114 \\
\hline
\end{tabular}

Fonte: Vital (1996)

1 o valor total de sedimentos deve ser multiplicado por 2 para a obtenção da produção total de sedimentos, que em geral corresponde a 50\% de sedimento em suspensão e 50\% de arraste.

Comparando o comportamento da microbacia para todo o período experimental, observa-se após o corte um aumento para os parâmetros cor (1,7 vezes maior), turbidez ( 1,3 vezes maior) e condutividade elétrica ( 1,4 vezes maior), em relação ao período anterior ao corte.

Segundo Câmara (1999), a erosão é responsável por $80 \%$ dos problemas de alteração da qualidade da água em microbacias hidrográficas. Em um experimento em Itatinga - SP, a autora constatou que a produção de sedimentos em suspensão representou um grande impacto causado pelo corte raso sobre a qualidade da água da 
microbacia, apresentando valores $52,7 \%$ superiores ao longo de todo o ano após o corte da floresta em relação à média dos seis anos anteriores, que foi de $28,7 \mathrm{~kg} / \mathrm{ha}$.

\subsection{Medidas de Controle da Erosão}

A solução dos problemas de erosão oriunda das estradas florestais geralmente se baseia nos princípios da prevenção (criteriosos planejamento e construção da estrada florestal, considerando os problemas potenciais e incluindo medidas preventivas como parte normal dos procedimentos de construção da estrada) e da correção (reparo de uma situação que originalmente não foi considerada no planejamento). A prevenção é o melhor caminho, por ser mais eficiente (Machado \& Souza, 1990).

As medidas preventivas podem ser realizadas através da minimização da extensão total das estradas, da locação de estradas em relação à topografia e aos solos, da minimização das superficies expostas da estrada através do alinhamento apropriado e da instalação adequada de bueiros e outras obras (FAO, 1989). De acordo com Patric \& Brink (1977), muitas práticas de controle da erosão em estradas são conhecidas, mas freqüentemente não são aplicadas, principalmente por razões econômicas.

De acordo com FAO (1989) e Kidd \& Megahan (1972), observações sugerem que as altas taxas iniciais de erosão são devidas à exposição do solo dos taludes de aterro das estradas. Assim, pode ser possível reduzir a sedimentação em estradas usando tratamentos de estabilização nos taludes de aterro. São citadas três medidas a serem seguidas no controle da erosão em estradas:

a) implementar as medidas de controle da erosão durante e imediatamente após a construção das estradas para máxima eficiência;

b) garantir os tratamentos de proteção da superficie do solo até que a vegetação esteja estabelecida;

c) aproveitar as barreiras naturais (troncos, galhos, etc.) para efetivamente reduzir o movimento de sedimentos ladeira abaixo. 
Segundo Holmes (1980), citado por Machado \& Souza (1990), a estabilidade dos taludes pode ser avaliada por meio dos fatores listados na Tabela 5.

Tabela 5. Avaliação da estabilidade do talude.

\begin{tabular}{ccccc}
\hline $\begin{array}{c}\text { Fator de } \\
\text { influência }\end{array}$ & A (4 pontos) & B (3 pontos) & C (2 pontos) & D (1 ponto) \\
\hline Talude & Alto da encosta & Longo da estrada & Próximo ao rio \\
Decliv. terreno & $<20 \%$ & Entre 20 e $25 \%$ & Entre 26 e $44 \%$ & $>44 \%$ \\
Solo instável & Nenhum & Pouco & Algum & Muito \\
Textura do solo & Média & Grossa & Muito grossa & Fina ou pedreg. \\
Cobertura do & Densa & Média & Cultivada & Perturbado $p /$ \\
solo & & & & uso \\
\hline
\end{tabular}

Fonte: Holmes (1980), citado por Machado \& Souza (1990)

1 diferente de B, C e D

$\mathrm{Na}$ avaliação de um talude, se a soma atingir entre 18 e 20 pontos, o talude é considerado estável; entre 12 e 17 pontos é relativamente estável; instável entre 10 e 11 pontos e altamente instável entre 5 e 9 pontos.

Kantola \& Harstela (1988) classificam os taludes de corte e aterro de acordo com sua declividade:

- 0-15\%: plano;

- $15-30 \%$ : suave;

- 30-50\%: moderado;

- 50-70\%: declivoso;

- $>70 \%$ : muito declivoso. 
De acordo com Machado \& Souza (1990), a declividade dos taludes de corte e aterro é fundamental para a determinação da natureza e do tipo de recuperação vegetal capaz de garantir a sua estabilização. Burroughs \& King (1989) ressaltam que quanto mais declivoso for o terreno, menos efetivo será o tratamento. Esta recuperação vegetal, além de promover o controle da erosão, deve atender também aos aspectos estéticos e ambientais. Quando a revegetação for a solução mais adequada para o controle da erosão nos taludes, a inclinação destes deverá permitir a fixação e o desenvolvimento das plantas indicadas.

As medidas de proteção da superfície devem considerar 3 aspectos: o clima, a vegetação e o microsítio. As informações climáticas referem-se principalmente à quantidade e distribuição das precipitações, além das temperaturas média, máxima e mínima e número de dias de geada por ano. A análise da vegetação inclui a adequação das espécies nativas ou exóticas na área em questão, considerando quais as plantas adaptam-se a uma ampla gama de condições, produzem boas sementes e possuem os melhores atributos no controle da erosão (crescimento rápido, boa cobertura do solo, características do sistema radicular). A avaliação do microsítio considera fatores como o microclima, topografia e solos (FAO, 1989).

De acordo com FAO (1977), a estabilização de taludes para prevenir ou limitar a erosão pode ser feita das seguintes maneiras:

a) construção de bancadas horizontais contínuas em intervalos ao longo do talude para interromper o fluxo de água;

b) colocação de gramado em linhas horizontais contínuas em intervalos de 1 a $2 \mathrm{~m}$ ao longo do talude;

c) semeadura e fertilização dos taludes e cobertura com feno, palha ou "mulch" (manta orgânica com sementes de gramíneas e leguminosas) para promover o crescimento da vegetação. 
Burroughs \& King (1989) ainda incluem a mistura de palha e asfalto, de palha com juta ou papel kraft, cascalho ou cavacos de madeira e "hydromulch", ou seja, uma mistura de material orgânico e sementes aplicada por meio aquoso. Porém, para estes autores, o tratamento com mantas de material orgânico impregnadas com sementes não é eficiente no controle da erosão em taludes de corte. Em um estudo de 3 anos na Bacia Horse Creek, localizada no nordeste do estado americano de Idaho, houve uma redução de somente $10 \%$ na produção de sedimentos em um talude de corte de gradiente $0,75: 1$.

Holmes (1980), citado por Machado \& Souza (1990), cita vários procedimentos de proteção e controle da erosão, descritos a seguir:

a) conhecimento do processo erosivo e identificação de seu principal tipo de ocorrência e fator de controle;

b) proteção de toda a vegetação ciliar, visando preservar a fauna e a flora e servir de filtro dos sedimentos provenientes do escoamento superficial;

c) nos pontos de travessia dos cursos d'água, recomenda-se um greide bem suave e igual antes e depois do cruzamento, de pelo menos $15 \mathrm{~m}$ de extensão, de forma a evitar o acúmulo de água na plataforma da estrada, que poderá erodir o seu leito e o talude de aterro e lançar os sedimentos diretamente nos cursos d'água. Todas as obras de arte devem ser construídas perpendicularmente aos cursos d'água, de modo a reduzir os distúrbios ao solo na área de construção;

d) colocação de bueiros em todos os locais de drenagem natural cortados pela estrada florestal, dimensionados adequadamente para suportar os picos de vazão, dando especial atenção à sua manutenção;

e) proteção de toda a área da faixa terraplenada da estrada florestal com vegetação, visando controlar a erosão;

f) manutenção adequada e freqüente da superfície da estrada para manter as condições de trafegabilidade dos veículos, garantindo uma boa drenagem e reduzindo a perda de solo;

g) construir estradas com a menor largura possível, limpando o mínimo de vegetação de suas margens durante a construção e a manutenção; 
h) a estabilização de encostas e taludes por meio de revestimento vegetal é a melhor prática a ser adotada pelo setor florestal. Os principais vegetais utilizados são as gramíneas e as leguminosas. Chang (1982) afirma que a produção de sedimentos pode ser eliminada pela presença de cobertura vegetal;

i) evitar que o maquinário de terraplenagem aproxime-se dos cursos d'água;

j) empregar inclinações de talude de corte e aterro adequadas ao tipo de solo e à declividade do terreno;

1) a construção de estradas, especialmente em regiões de solos instáveis e/ou siltosos deverá ser executada, necessariamente, na época seca;

m) compactação e proteção dos aterros com vegetação, de modo que haja redução da erosão.

Robichaud et al. (1991) recomendam ainda a colocação de cascalho na superfície da estrada, vegetação nos taludes de corte e aterro, rochas nos canais de drenagem e redução na pressão nos pneus dos caminhões para diminuir a produção de sedimentos nas estradas florestais.

A cobertura vegetal é muito importante na redução da erosão superficial. Blauer et al. (1993) afirmam ser importante medir a porcentagem de cobertura das plantas no terreno para medir o desempenho de cada tratamento. Eles sugerem que a taxa de cobertura seja determinada usando um quadrado de $1 \mathrm{~m}^{2}$ locado ao longo dos tratamentos nos vários locais de estudo, e dividindo os valores de cobertura em classes: (1) $<1 \%$; (2) $1-5 \%$; (3) $5-25 \%$; (4) $25-50 \%$; (5) 50-75\%; (6) $75-95 \%$; (7) $>95 \%$.

Grace III et al. (1996), Kantola \& Harstela (1988) e Gonsoir \& Gardner (1971) afirmam que o estabelecimento de plantas é o principal impedimento à erosão superficial. Segundo Astete (1985), a melhor maneira de combater a erosão é manter o solo coberto, não somente com vegetação herbácea, mas também com resíduos. Porém, Burroughs \& King (1989) ressaltam que sementes sozinhas não controlam a erosão até a germinação e crescimento das plantas, podendo ser lavadas pela água. 
De acordo com Bertoni \& Lombardi Neto (1990), a cobertura vegetal é a defesa natural de um terreno contra a erosão. $O$ efeito da vegetação pode ser assim enumerado: (1) proteção direta contra o impacto das gotas de chuva; (2) dispersão da água, interceptando-a e evaporando-a antes que atinja o solo; (3) decomposição das raizes das plantas que, formando canalículos no solo, aumentam a infiltração da água; (4) melhoramento da estrutura do solo pela adição de matéria orgânica, aumentando assim sua capacidade de retenção de água; (5) diminuição da velocidade de escoamento da enxurrada pelo aumento do atrito na superficie.

Além disso, a cobertura vegetal reduz a água presente no solo por evapotranspiração, mantém altas as taxas de infiltração, o sistema radicular une as partículas do solo em agregados, contribuindo para aumentar a estabilidade das encostas, e é um meio simples e barato de estabilizar as superficies de solo desprotegido. Abe \& Ziemer (1991) afirmam que a freqüência de desmoronamentos do talude pode aumentar depois que uma área é desmatada. Embora a cobertura com plantas desempenhe um importante papel na prevenção da erosão superficial, é importante observar o tipo de planta, pois as baixas que crescem densas, como as ervas, são mais eficientes do que as que crescem mais altas, como o trigo e a aveia. $O$ controle efetivo da erosão é também dependente do rápido crescimento inicial e recobrimento do solo (FAO, 1989; Astete, 1985; Belt \& Woo, 1979).

A Tabela 6 mostra as perdas por erosão (médias ponderadas para três tipos de solo do Estado de São Paulo) de acordo com o uso do solo. 
Tabela 6. Efeito do tipo de uso do solo sobre as perdas por erosão.

\begin{tabular}{ccc}
\hline Uso & \multicolumn{2}{c}{ Perdas } \\
\cline { 2 - 3 } do solo & Solo & Agua \\
& $(\mathrm{t} / \mathrm{ha})$ & $(\%$ da chuva $)$ \\
\hline Mata & 0,004 & 0,7 \\
Pastagem & 0,4 & 0,7 \\
Cafezal & 0,9 & 1,1 \\
Algodoal & 26,6 & 7,2 \\
\hline
\end{tabular}

Fonte: Bertoni \& Lombardi Neto (1990)

De acordo com FAO (1989), o objetivo das técnicas de estabilização é o estabelecimento, o mais rápido possível, de uma densa cobertura de vegetação a fim de minimizar as fontes de sedimento. As plantas nativas geralmente requerem menores despesas e manutenção e são visualmente harmoniosas com a paisagem, embora muitas espécies exóticas sejam cultivadas especificamente para controle da erosão, podendo ser igualmente satisfatórias.

Machado \& Souza (1990) citam duas áreas, uma com $75 \%$ e outra com $10 \%$ de cobertura florestal, com o mesmo tipo de solo. Sob a ação de uma mesma precipitação, a erosão resultante é de 100 e $10000 \mathrm{~kg} / \mathrm{ha}$, respectivamente. Estes valores comprovam a hipótese de que o controle da densidade da rede viária e o tamanho da faixa terraplenada da estrada florestal são fundamentais para a redução do impacto ambiental.

De acordo com DERSA (1975), a mistura de gramíneas e leguminosas é a melhor alternativa de revegetação nos taludes de corte e aterro, onde a manutenção é onerosa e de dificil execução, seja ela manual ou mecanizada. A espécie leguminosa vai repor o nitrogênio no solo. Porém, deve ser observado se as plantas foram tratadas com o inoculante da bactéria associada. A desvantagem das leguminosas é que elas são muito 
apreciadas como alimento por animais, que podem criar uma condição mais erosiva do que antes do tratamento. As vantagens e desvantagens desta consorciação são:

$\rightarrow$ Vantagens:

- praticamente toda a manutenção dispendiosa que seria necessária ao gramado será dispensável ao se utilizar esse sistema (elimina-se as podas e a adubação nitrogenada);

- o aspecto visual da vegetação é agradável, permanecendo verde o ano todo;

- a cobertura do solo será completa e segura contra a erosão.

$\rightarrow$ Desvantagens:

- necessita adubação de cobertura, principalmente com fósforo e potássio durante 3 anos após o plantio até o estabelecimento definitivo do revestimento;

- são necessários alguns tratos culturais.

As espécies de grama e leguminosas, além de formarem uma camada densa e fibrosa que protege o solo, também melhoram o balanço orgânico e nutricional do solo. Elas agem como "plantas enfermeiras" para as plantas nativas jovens, porque reduzem a perda de umidade do solo e provêm sombra. Geralmente, a grama é considerada prejudicial ao desenvolvimento das outras plantas, mas neste caso isto não ocorre. É recomendada a mistura de pelo menos 3 espécies para assegurar uma contínua proteção do solo de um talude. Alguns fatores devem ser considerados na seleção da mistura apropriada:

- estabilidade do declive, ângulo e exposição;

- condições climáticas;

- características químicas e físicas do solo;

- considerações estéticas e visuais;

- susceptibilidade a ataques de animais;

- competição entre as espécies plantadas e as nativas (FAO, 1989).

Segundo DERSA (1975), as placas de grama "Batatais" são bastante utilizadas em revestimento de taludes de corte e aterro em rodovias, promovendo uma rápida 
cobertura do terreno a um baixo custo, além de ser resistente no estágio inicial de desenvolvimento. Para fins de manutenção, pode-se classificar os gramados de "Batatais" em quatro tipos (Tabela 7).

Tabela 7. Classificação de gramados de grama "Batatais".

\begin{tabular}{cccc}
\hline Tipo & Características do gramado & $\%$ de cobertura & Grau de erosão \\
\hline 1 & Ótima cobertura vegetal; & $\geq 95$ & Ausente \\
& ótimo aspecto visual & & Ausente \\
2 & Cobertura regular; aspecto & $70-95$ & Ausente ou sulcos de até \\
& visual bom & & 10 cm de profundidade \\
3 & Cobertura deficiente; mau & $50-70$ & Adiantado, com sulcos \\
& aspecto visual & & maiores do que $10 \mathrm{~cm}$ de \\
& Cobertura péssima; péssimo & & profundidade
\end{tabular}

Fonte: DERSA (1975)

Nos consórcios entre gramíneas e leguminosas, a freqüência das manutenções é bastante restrita após o estabelecimento da vegetação, destacando-se as seguintes operações:

a) adubação: em cobertura, feita de março a abril, anualmente, utilizando-se a fórmula 5-15-5 (nitrogênio-fósforo-potássio) $+5 \%$ de enxofre e boro, na quantidade de $600 \mathrm{~kg} / \mathrm{ha} / \mathrm{ano}$;

b) erradicação de árvores e outras espécies invasoras de grande porte que possam comprometer a estabilidade e os aspectos visual e paisagístico da área;

c) controle das pragas e doenças (DERSA, 1975).

Muitas vezes somente a vegetação não é suficiente para prevenir a erosão em taludes longos e muito declivosos. Coelho (1998) define como bioengenharia as técnicas 
utilizadas na cobertura dos taludes das estradas a fim de controlar a erosão, empregando elementos inertes como madeira e fibras sintéticas juntamente com a vegetação. $O$ autor enumera diferentes vantagens deste método, entre elas:

- menor requerimento de maquinaria, já que empregam maior quantidade de mão-deobra;

- utilização de materiais naturais e existentes no próprio local, reduzindo os custos de transporte;

- menor requerimento de movimentação de terra, o que ocasiona menor perturbação durante a execução de obras de controle da erosão;

- melhoramento da estrutura e resistência do solo com o passar do tempo devido à vegetação;

- facilidade de execução em locais de difícil acesso.

Solos muito perturbados ou com muita matéria orgânica necessitam de camadas adicionais de proteção, como cavacos de madeira e palha. Os cavacos de madeira proporcionam a melhor proteção, devendo ser aplicados a uma taxa de 1,2 a 1,5 t/ha. Valores maiores melhoram o controle da erosão, mas inibem o estabelecimento das plantas (FAO, 1989). A palha é muito eficiente quando aplicada a uma média de $5 \mathrm{t} / \mathrm{ha}$, protegendo também mecanicamente. Recomenda-se a utilização de palha limpa para evitar a introdução de plantas nocivas.

A eficiência de cada tratamento aumenta com o aumento na cobertura do terreno. Comparando-se os tratamentos aplicados em relação à porcentagem de redução na produção de sedimentos, pode-se concluir que o mais eficiente foi palha com asfalto aderido (Tabela 8). 
Tabela 8. Eficiência dos tratamentos citados acima no controle da erosão, considerando $50 \%$ de cobertura do solo para todos os tratamentos.

\begin{tabular}{cc}
\hline Tratamento & Eficiência \\
\hline palha com asfalto & $79 \%$ \\
palha com juta ou papel kraft & $60 \%$ \\
somente palha & $58 \%$ \\
telas para controle da erosão & $52 \%$ \\
cascalho/cavacos de madeira & $50 \%$ \\
"hydromulch" & $0 \%$ \\
\hline
\end{tabular}

Fonte: Burroughs \& King (1989)

O "hydromulch" não mostra a mesma relação dos outros tratamentos entre cobertura e redução da erosão, requerendo altas porcentagens de cobertura do solo para ser eficiente, porque é constituido por fibras curtas que podem ser facilmente desprendidas e transportadas no escoamento superficial. O desempenho das esteiras ou telas depende da uniformidade do terreno, sendo que deve haver um bom contato entre a tela e o solo para efetivo controle da erosão.

Medidas mecânicas de estabilização de superficies são constituídas por terraços, canais, escarificação e degraus de 60 a $120 \mathrm{~cm}$ cortados vertical e horizontalmente ao longo do talude, sendo depois semeados normalmente. Eles são somente eficientes no caso de taludes de corte formados por rocha ou material semelhante que permaneça verticalmente por vários anos em alturas aproximadas de $1 \mathrm{~m}$. Escarificar taludes não é esteticamente agradável, mas esta técnica é eficiente em aumentar a infiltração e impedir o escoamento. Além disso, a escarificação forma pequenas depressões no terreno que ajudam na retenção das sementes e do "mulch" (FAO, 1989).

De acordo com FAO (1989), também podem ser combinadas técnicas de estabilização mecânicas e naturais, com trançados de varas e galhos dispostos ao longo 
do declive para diminuir a velocidade da água e, conseqüentemente, o escoamento superficial, além da vegetação com grama, arbustos e árvores. Para FAO (1977) e Kantola \& Harstela (1988), podem ser construídas também armações de madeira roliça e tratada, localizadas sobre o talude, que irão segurar os sedimentos e estabilizar o talude. Além disso, a erosão pode ser reduzida cavando-se canais sobre o topo do talude, para que a água não deslize por ele e carregue sedimentos para a estrada.

De acordo com Burroughs \& King (1989), podem ser construídas barreiras com os resíduos do corte que diminuem a velocidade do escoamento, causando deposição da maior parte dos sedimentos. Elas podem ser localizadas no próprio aterro ou imediatamente abaixo dele. A vantagem desse tratamento é que ele pode ser construído juntamente com a estrada para promover controle imediato sobre a produção de sedimentos do aterro. Este método, após 3 anos, reduziu em 75 a $85 \%$ a produção de sedimentos que deixavam o aterro.

Segundo os autores anteriores, o sucesso dos tratamentos de controle da erosão superficial em taludes de corte e aterro depende do tempo de aplicação da medida de controle, do tipo de tratamento, da taxa de aplicação dos tratamentos, da erodibilidade do solo e dos gradientes de declividade do talude e da estrada.

Grace III et al. (1996) testaram três coberturas no controle da erosão em cortes e aterros: esteira de madeira, grama nativa e grama exótica. $O$ tratamento de esteira foi o mais efetivo na redução da produção de sedimentos, proporcionando uma redução de $98,6 \%$ nos cortes e $88,3 \%$ nos aterros, quando comparados à testemunha. A grama exótica foi o segundo tratamento mais efetivo, com $93 \%$ de redução na produção de sedimentos em cortes e $86,8 \%$ em aterros. A grama nativa foi o menos efetivo, com $66,3 \%$ de redução nos cortes e $80,9 \%$ nos aterros. Porém, não houve diferença estatística entre os tratamentos. 
De acordo com Burroughs \& King (1989), camadas densas de grama são eficientes em reduzir a erosão. Uma vez que a grama está estabelecida, a redução de sedimentos varia entre 86 e 100\%, dependendo da densidade de cobertura do solo. Em um experimento conduzido em um aterro na Carolina do Norte (EUA), do $6^{\circ}$ ao $14^{\circ}$ mês seguintes à semeadura, as taxas de produção de sedimentos foram reduzidas em $97 \%$. No mesmo experimento, mas conduzido em um talude de corte, a redução na produção de sedimentos foi de $89 \%$.

Na Carolina do Norte (EUA), Swift (1984), citado pelos autores anteriores, coletou dados de sedimentos em aterros por 9,5 meses após a construção da estrada, durante os quais o aterro não foi semeado. Esses dados foram comparados com os coletados durante os primeiros 5 e 13,3 meses seguintes à semeadura com grama, que mostraram reduções médias de 7 e $58 \%$, respectivamente. Wollum (1962), também citado por Burroughs \& King (1989), relatou uma redução de $68 \%$ na erosão durante o primeiro ano após a semeadura, comparando com a pré-semeadura, em um talude de aterro de gradiente 1,25:1.

Kidd \& Megahan (1972) determinaram, para um estudo de 6 anos em Idaho Batholith (EUA), a taxa de controle da erosão para diferentes tratamentos, que pode ser visualizado na Tabela 9. Todos os tratamentos, exceto aquele com Pinus ponderosa, incluíram sementes de grama e fertilizantes. 
Tabela 9. Medidas de controle da erosão pela estabilização de taludes em Idaho Batholith (EUA).

\begin{tabular}{cc}
\hline Medida de estabilização & \% de variação da erosão \\
\hline Pinus ponderosa & -47 \\
Cavaco de madeira & -61 \\
Palha & -72 \\
Mulch palha-asfalto & -97 \\
Mulch palha+esteira & -99 \\
\hline
\end{tabular}

Fonte: Kidd \& Megahan (1972)

${ }^{1}$ comparado com parcelas sem tratamento

O terraceamento é eficiente na redução da quantidade de solo retirada dos aterros. A erosão pode até permanecer alta, mas o solo erodido é depositado nos terraços em vez de ser transportado para fora do talude. Megahan (1984), citado por Burroughs \& King (1989), relatou que taludes de corte terraceados e semeados em Idaho Batholith (EUA) resultaram em uma redução na produção de sedimentos de $86 \%$.

Grace III et al. (1996), comparando diferentes coberturas no controle da erosão, concluíram que o custo relativo à utilização de esteira de madeira foi o mais alto entre todos, totalizando U\$ $10.359 /$ ha, sendo que os tratamentos que empregaram grama custaram U\$2.470/ha. O custo da esteira deve ser justificado se a estrada for construída próxima a áreas sensiveis, que podem ser prejudicadas pelo aumento da poluição das correntes, reservatórios ou áreas de recreação. Também deve ser considerado o custo de manutenção, que será menor quanto maior for o custo de implantação. 


\section{MATERIAL E MÉTODOS}

\section{1 Área experimental}

O estudo foi conduzido em um talude de estrada com declividade média de 85\%, localizado na Fazenda São Silvestre, pertencente à Votorantim Celulose e Papel, no Município de Jacareí, Estado de São Paulo. A fazenda possui área total de 289,89 ha e uma área de efetivo plantio de 185,79 ha com Eucalyptus saligna, implantado em 1994, fazendo parte da Bacia do Paraíba do Sul, pertencente à $6^{\mathrm{a}}$ Zona Hidrográfica e Subzona Hidrográfica 61 do Estado de São Paulo (São Paulo, 1984).

O local foi escolhido por possuir extensões horizontal e vertical, além da declividade, compatíveis com a instalação das parcelas e com o objetivo do trabalho. As coordenadas são $23^{\circ} 26^{\prime}$ de latitude Sul e $46^{\circ} 01^{\prime}$ de longitude Oeste. A altitude média é de $720 \mathrm{~m}$.

\subsubsection{Clima}

A região possui uma precipitação média anual de $1543,7 \mathrm{~mm}$ (São Paulo, 1993). A temperatura máxima média é de $26^{\circ} \mathrm{C}$ e a temperatura mínima média é de $17^{\circ} \mathrm{C}$, resultando em uma temperatura média compensada de $21^{\circ} \mathrm{C}$ (Nascimento \& Pereira, 1988).

Segundo a classificação de Köeppen, a área compreende o tipo climático Cwa (Villa Nova et al., 1986). Isto corresponde ao clima temperado de inverno seco e verão chuvoso, onde a temperatura do mês mais frio é inferior a $18^{\circ} \mathrm{C}$, a temperatura do mês 
mais quente ultrapassa $22^{\circ} \mathrm{C}$, o índice pluviométrico varia entre 1100 e $1700 \mathrm{~mm}$ anuais e a estação seca ocorre entre os meses de abril e setembro (Brasil, 1979).

Durante o periodo experimental, correspondente a 12 meses (de janeiro a dezembro de 1999), a precipitação total foi de $1122,5 \mathrm{~mm}$, estando mais detalhada na Figura 1.

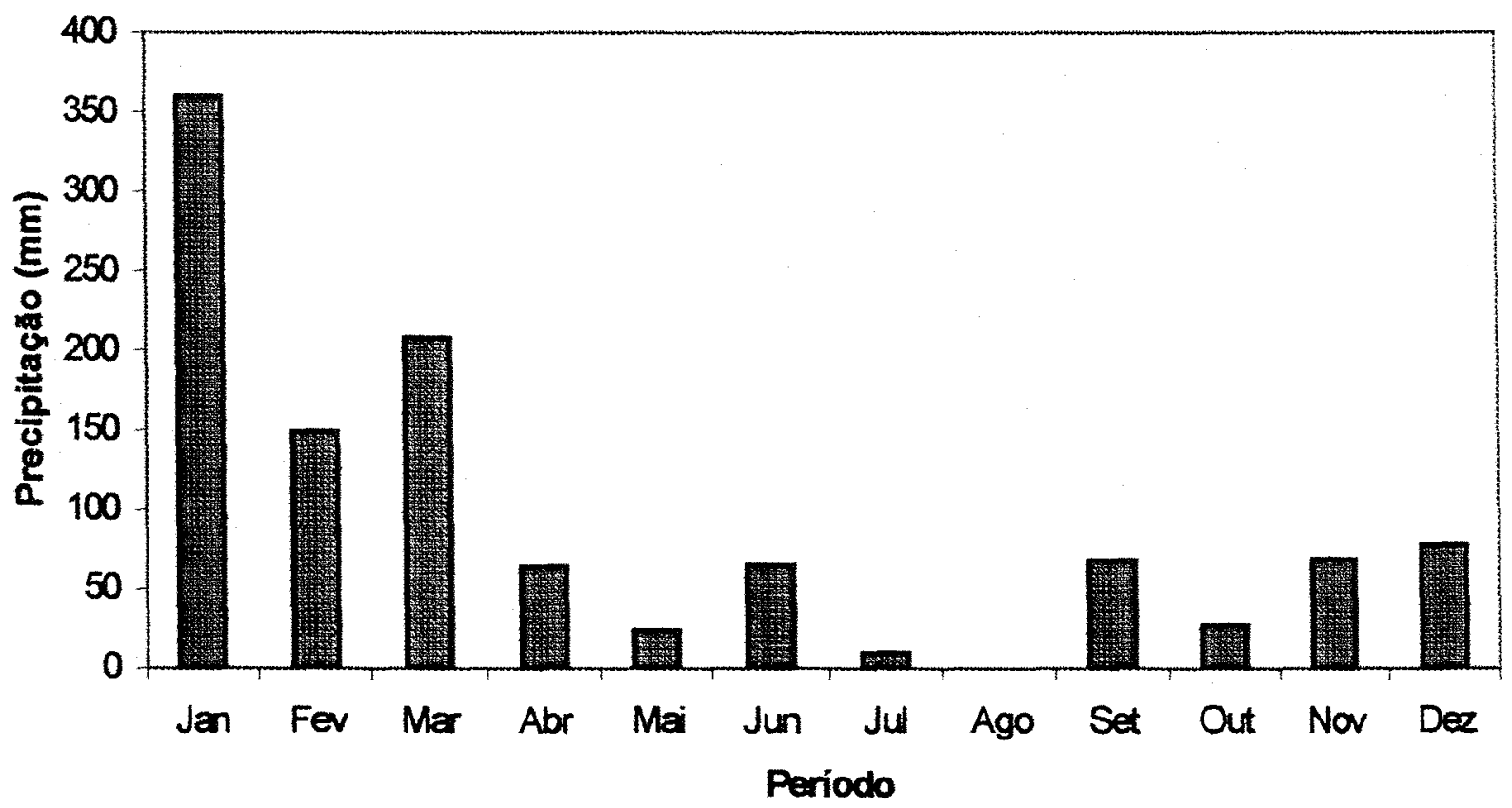

Figura 1. Precipitação mensal durante o período experimental.

\subsubsection{Geologia e geomorfologia}

A geologia da região de estudo é arqueana e situa-se no Complexo Paraiba do Sul, que abrange um agrupamento composto predominantemente por gnaisses e migmatitos, além de subunidades de rochas granitóides e metabásicas, lentes de quartzitos, anfibolitos e mármores (Brasil, 1983). 
Morfologicamente, pertence aos domínios morfo-estruturais-faixas de dobramentos remobilizados, região das escarpas e reversos da Serra do Mar, cuja topografia apresenta relevos com grandes desniveis altimétricos, vales alongados, segmentos de drenagem retilíneos, linhas de cristais e de cumeadas paralelas. A unidade geomorfológica é o Planalto do Paraitinga-Paraibuna, onde o comportamento espacial da rede de drenagem apresenta-se fundamentado na organização tectônica da área, com padrão retangular a subdendrítico adaptado ao sistema de falhas e fraturas (Brasil, 1983).

\subsubsection{Solos}

O solo da área experimental pertence à classe do Podzólico Vermelho-Amarelo, formado a partir de sedimentos argilosos. Este tipo de solo é moderadamente drenado, devido à sua baixa permeabilidade, sendo ácido a medianamente ácido com saturação de bases baixa. A análise textural encontra-se na Tabela 10 .

Tabela 10. Análise textural do solo do local do experimento.

\begin{tabular}{cccccccc}
\hline \multicolumn{3}{c}{ Areia (\%) } & $\begin{array}{c}\text { Silte } \\
(\%)\end{array}$ & $\begin{array}{c}\text { Argila } \\
(\%)\end{array}$ & $\begin{array}{c}\text { Dens. Apar. } \\
\mathrm{g} / \mathrm{cm}^{3}\end{array}$ & $\begin{array}{c}\text { Dens. Real } \\
\mathrm{g} / \mathrm{cm}^{3}\end{array}$ \\
\hline Grossa & Média & Fina & Total & $(24$ & 12 & 1,2 & 2,6 \\
\hline 13 & 15 & 36 & 64 & 24 &
\end{tabular}

\subsubsection{Vegetação}

A vegetação original da região era do tipo ombrófila densa. Os ambientes deste tipo de vegetação apresentam chuvas bem distribuídas com médias anuais em torno de $1500 \mathrm{~mm}$, havendo estações sem seca ou mesmo com grande disponibilidade de umidade. A influência antrópica alterou completamente a região, com a substituição da vegetação original por pastagens e reflorestamentos de eucalipto, já que a topografia local não permite culturas agrícolas. Isto acelerou o desenvolvimento dos processos morfogenéticos, originando sulcos, ravinas, voçorocas e movimentos de massa, que são generalizados em toda a área (Brasil, 1983; Ventura et al., 1965/66). 
No estudo da aptidão agrícola do Estado de São Paulo, o Município de Jacareí encontra-se na Mesorregião 2, Microrregião 259, correspondendo ao Vale do Paraíba Paulista. Assim, a área é apropriada para usos menos intensivos, como a pastagem plantada e a silvicultura, sendo inapta para culturas de ciclo curto (Brasil, 1979).

\subsection{Métodos}

\subsubsection{Experimento}

Foram avaliados três tipos de cobertura orgânica como material de proteção contra a erosão em taludes, além do solo desnudo como testemunha. Através da Figura 2 têm-se uma visão geral da área do experimento. Os tratamentos empregados foram:

- Tratamento A: testemunha, solo descoberto (Figura 3);

- Tratamento B: colocação de placas de grama "Batatais" (Paspalum notatum Flügge) (Figura 4);

- Tratamento C: cobertura do solo com casca de Eucalyptus spp. picada (resíduo da indústria de papel e celulose) (Figura 5);

- Tratamento D: cobertura do solo com tela de material orgânico impregnada com sementes de gramíneas e leguminosas (Figura 6). As quantidades de sementes utilizadas por parcela foram $175 \mathrm{~g}$ de gramíneas - braquiária (Brachiaria decumbens Stapf) e capim gordura (Melinis minutiflora Beauv.) e 10,5 g de leguminosas - feijão guandu (Cajamus cajan) e soja perene (Neonotonia wightii).

O experimento foi realizado em 5 blocos ao acaso, a fim de minimizar a variação devida à locação de parcelas ao longo da estrada. As parcelas tinham $3,5 \mathrm{x}$ 2,0 m, e estavam locadas com a maior extensão no sentido do comprimento do declive. Cada parcela teve seus limites cercados com tábuas de madeira, de $30 \mathrm{~cm}$ de altura, com a calha de coleta conectada por tubos de PVC a recipientes de armazenagem (baldes plásticos de 100 litros). 


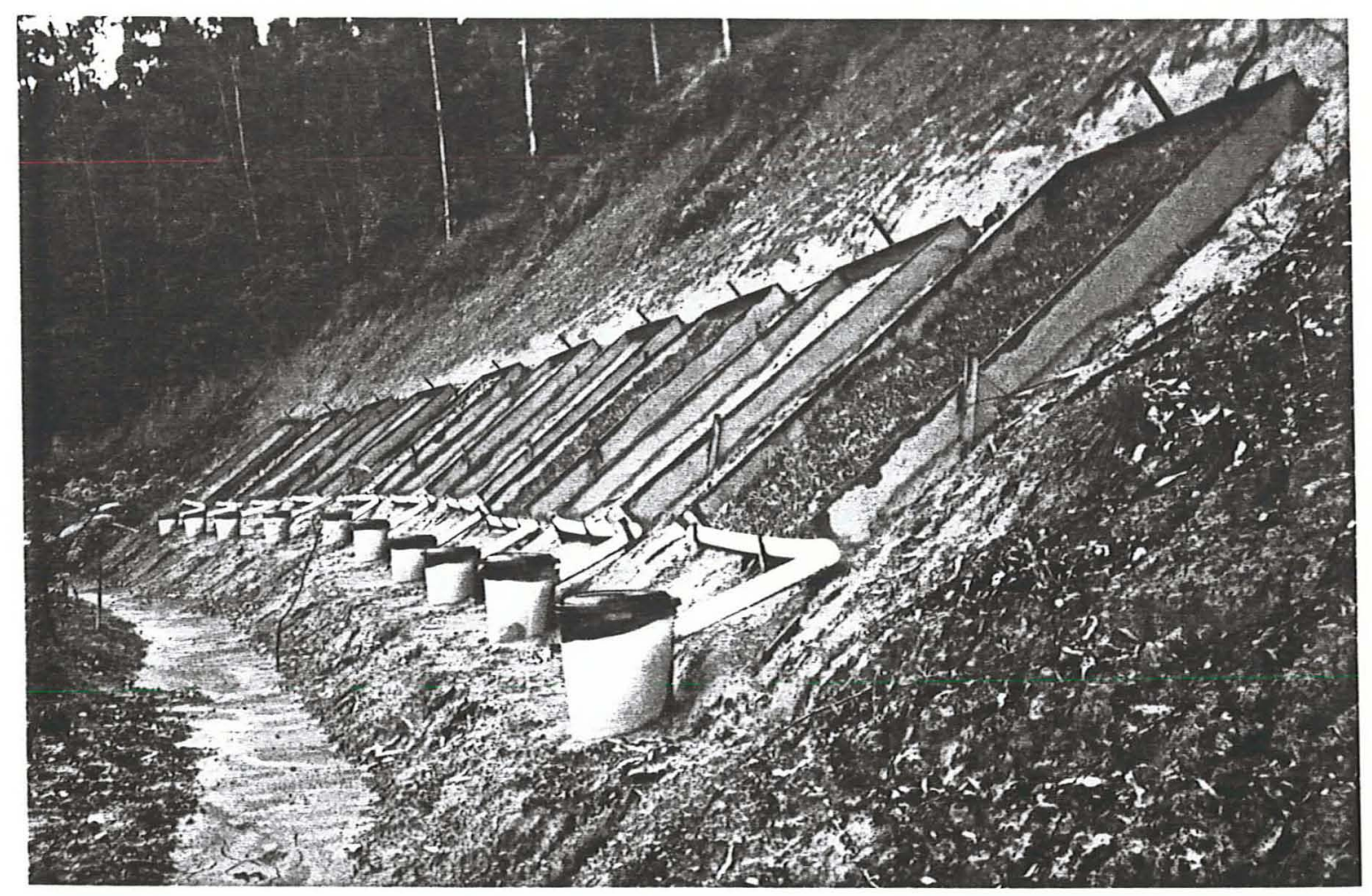

Figura 2. Vista geral da área do experimento.

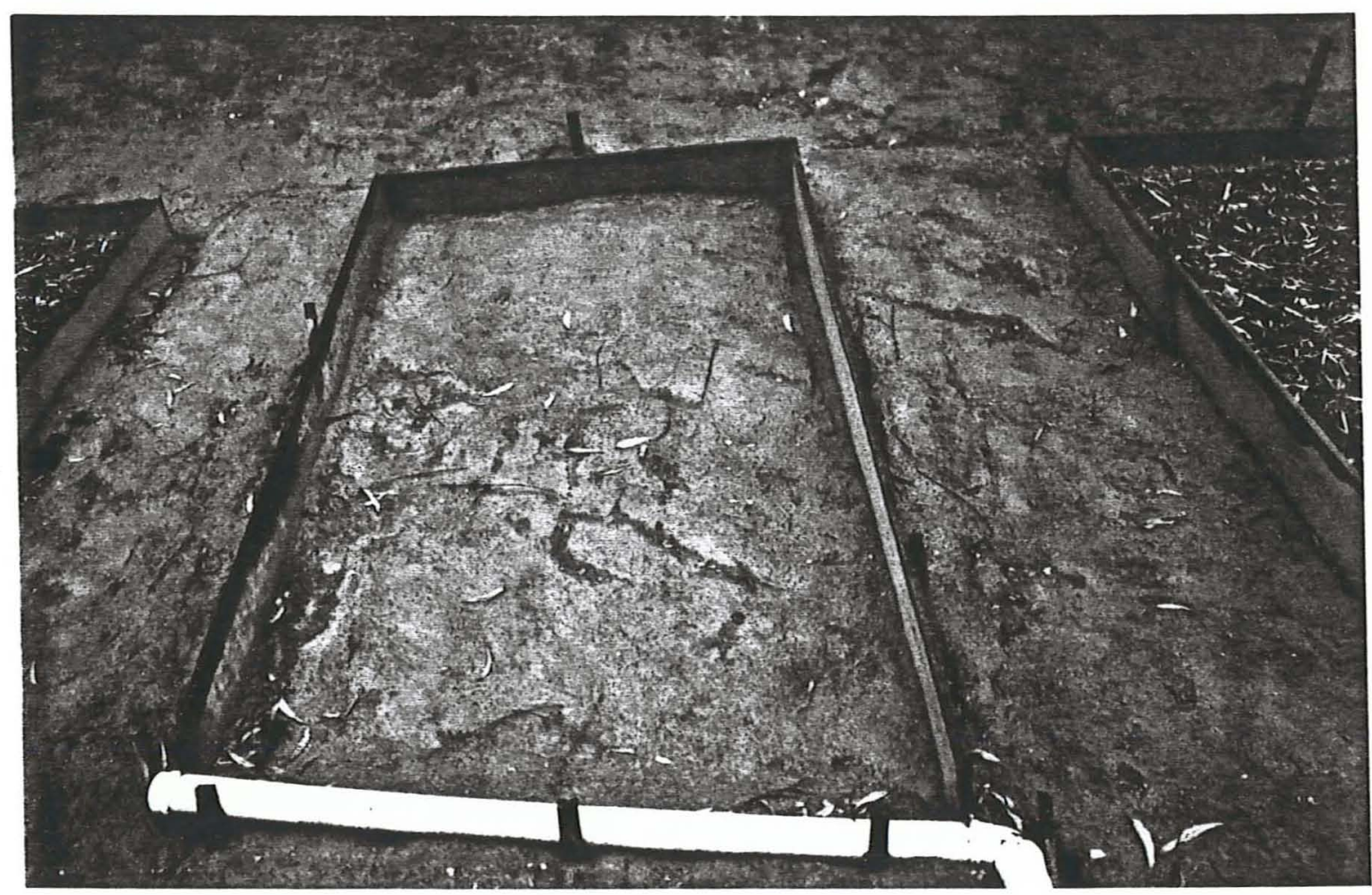

Figura 3. Tratamento A (testemunha). 


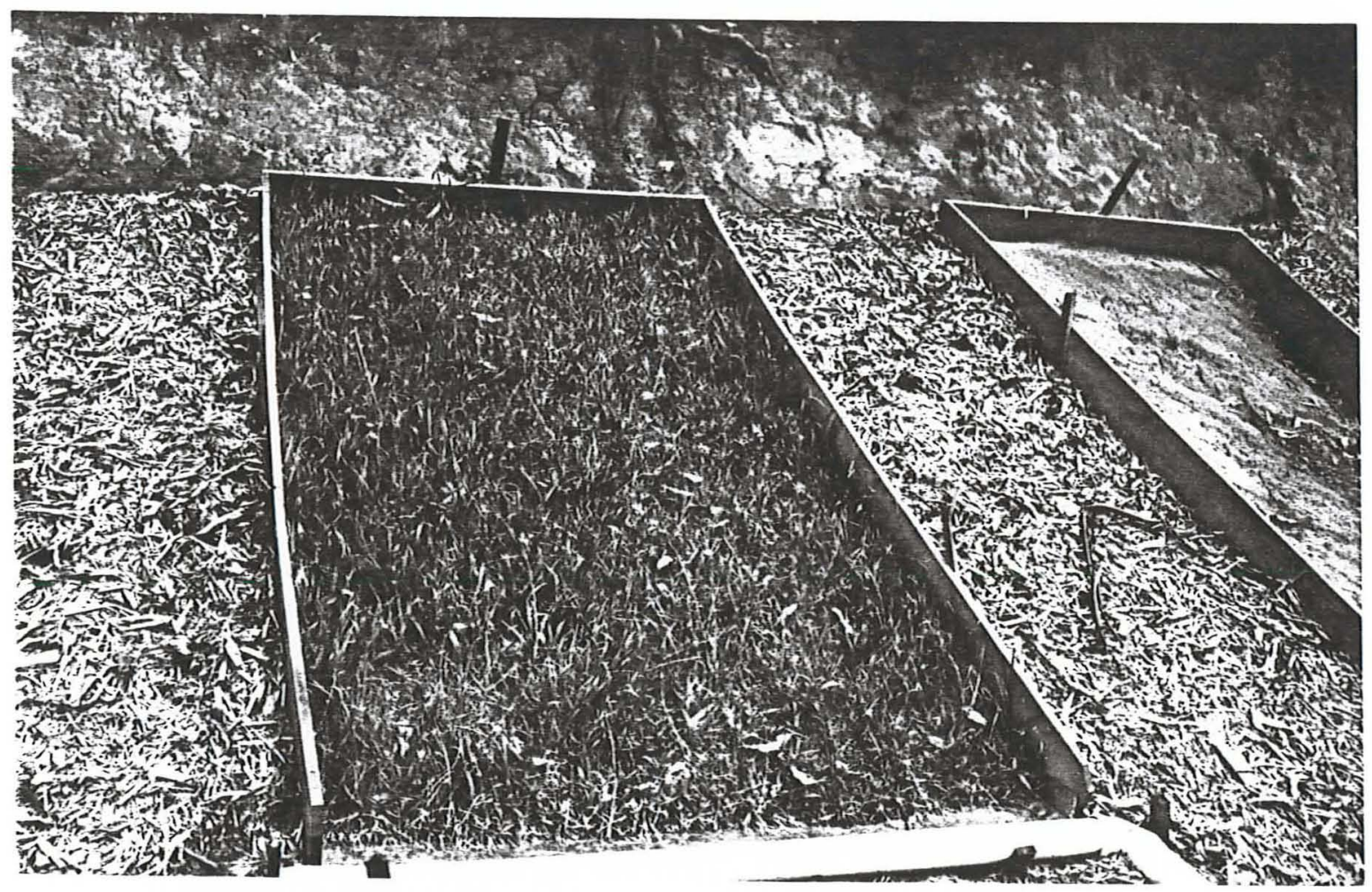

Figura 4. Tratamento B (grama "Batatais").

A grama "Batatais" é recomendada para o controle da erosão em locais declivosos, por ser resistente e formar um gramado denso, fixando-se bem ao solo. Também é resistente à seca, ao fogo, ao frio e a pragas e doenças, além de exigir irrigação mínima (Coelho, 1994). Este tratamento foi instalado com facilidade e se estabeleceu satisfatoriamente. 


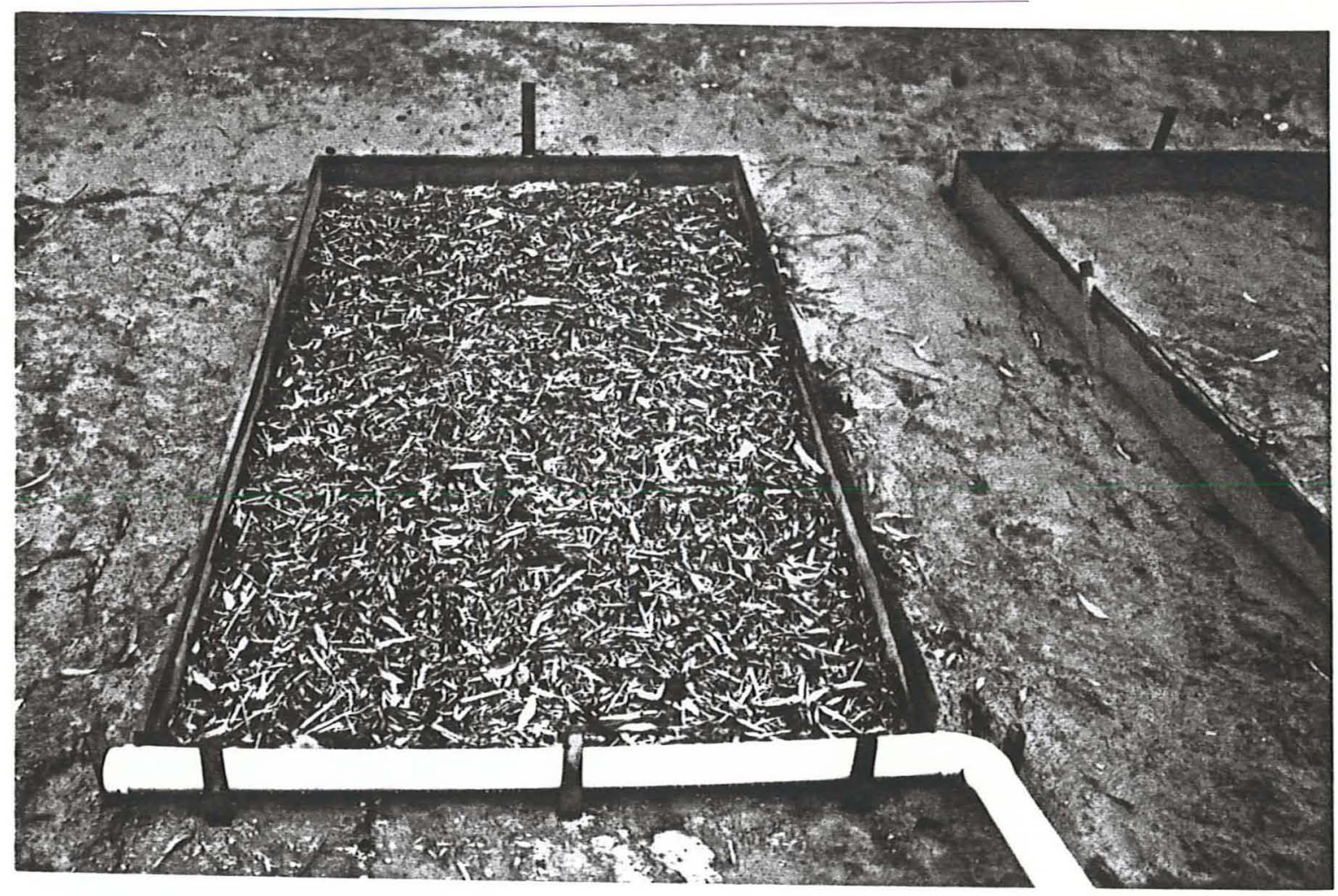

Figura 5. Tratamento C (casca).

O material utilizado no tratamento $\mathrm{C}$ é um resíduo gerado pelo sistema de consumo de madeira da VCP, composto predominantemente por casca de Eucalyptus grandis, E. saligna e E. urograndis, além de uma pequena quantidade de cavaco de madeira. Foi aplicada a uma taxa de $18 \mathrm{~kg} / \mathrm{m}^{2}$, com uma espessura de aproximadamente $10 \mathrm{~cm}$. Este foi o tratamento que apresentou maior grau de dificuldade na instalação, porque escorregava muito, devido à alta declividade do local. Para resolver o problema foram utilizadas pequenas estacas de bambu no interior da parcela, que ajudaram a manter a casca no local. Deve-se ressaltar que posteriormente não houve problema algum com este tratamento, e a casca permaneceu no local com um ótimo indice de cobertura da parcela. 


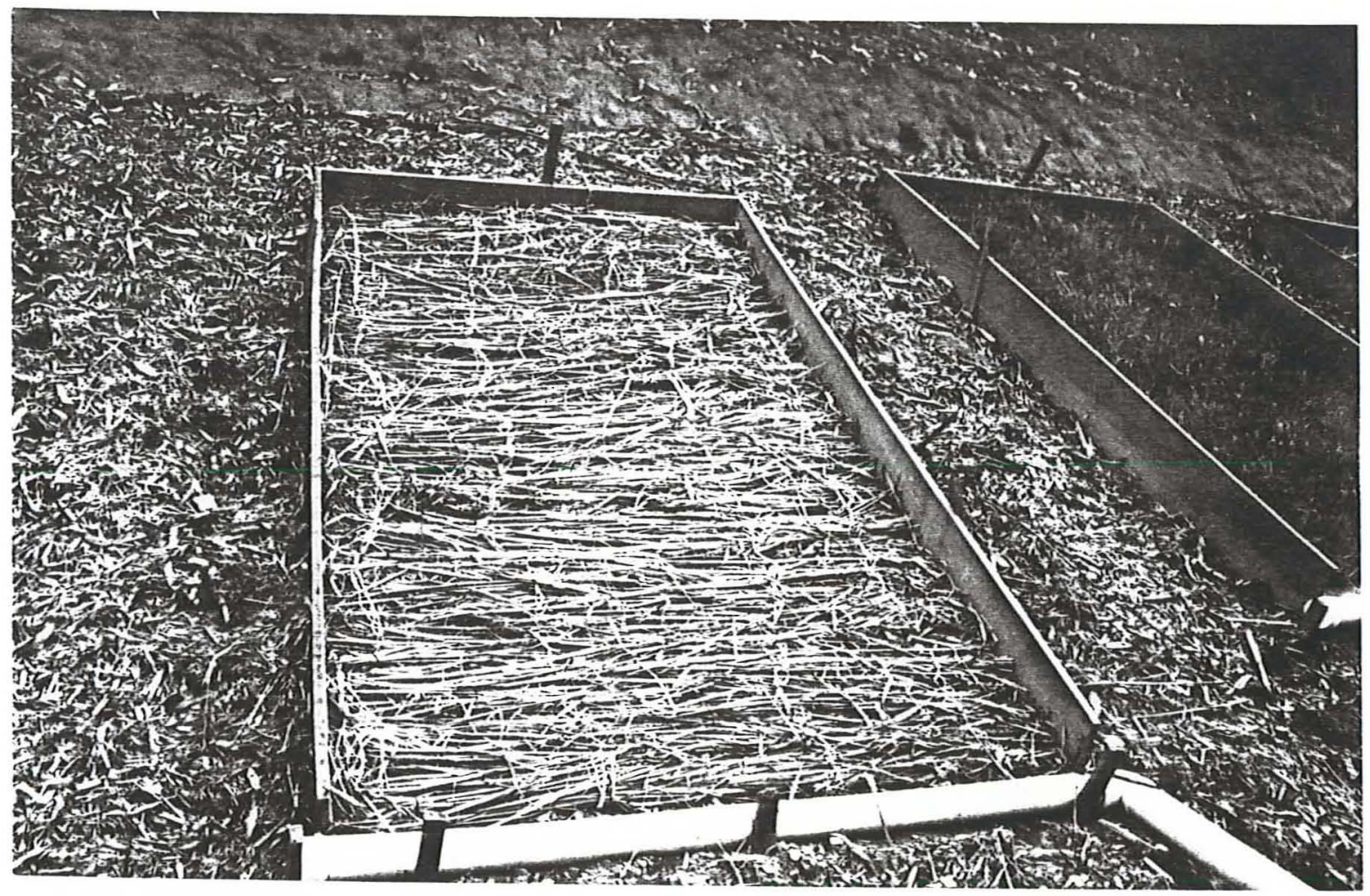

Figura 6. Tratamento D (tela vegetal).

A tela vegetal é constituída de material orgânico desidratado (o que conserva a característica vegetal e os nutrientes ali contidos) retido por uma rede de fios degradáveis. Após a aplicação, este material melhora o aspecto visual da área, facilita a infiltração de água no solo (minimizando o escoamento superficial) e evita a formação de pontos erosivos, além de iniciar uma lenta decomposição. Com o passar do tempo, cria um ambiente favorável à germinação das sementes de gramíneas e leguminosas aplicadas (Deflor, 1998). Foi o tratamento que apresentou maior facilidade de instalação, sendo aplicada a uma taxa de $2,0 \mathrm{~kg} / \mathrm{m}^{2}$. Foram colocadas duas camadas de tela porque, com a colocação de apenas uma, grande parte do solo da parcela permanecia exposto, e avaliou-se que a proteção contra a erosão não seria suficiente. 
Deve-se ressaltar que, devido à alta declividade do local, foi necessária a colocação de estacas de bambu nos tratamentos B e C e grampos de fixação no tratamento D para que os materiais permanecessem fixos no local (Figuras 7 e 8).

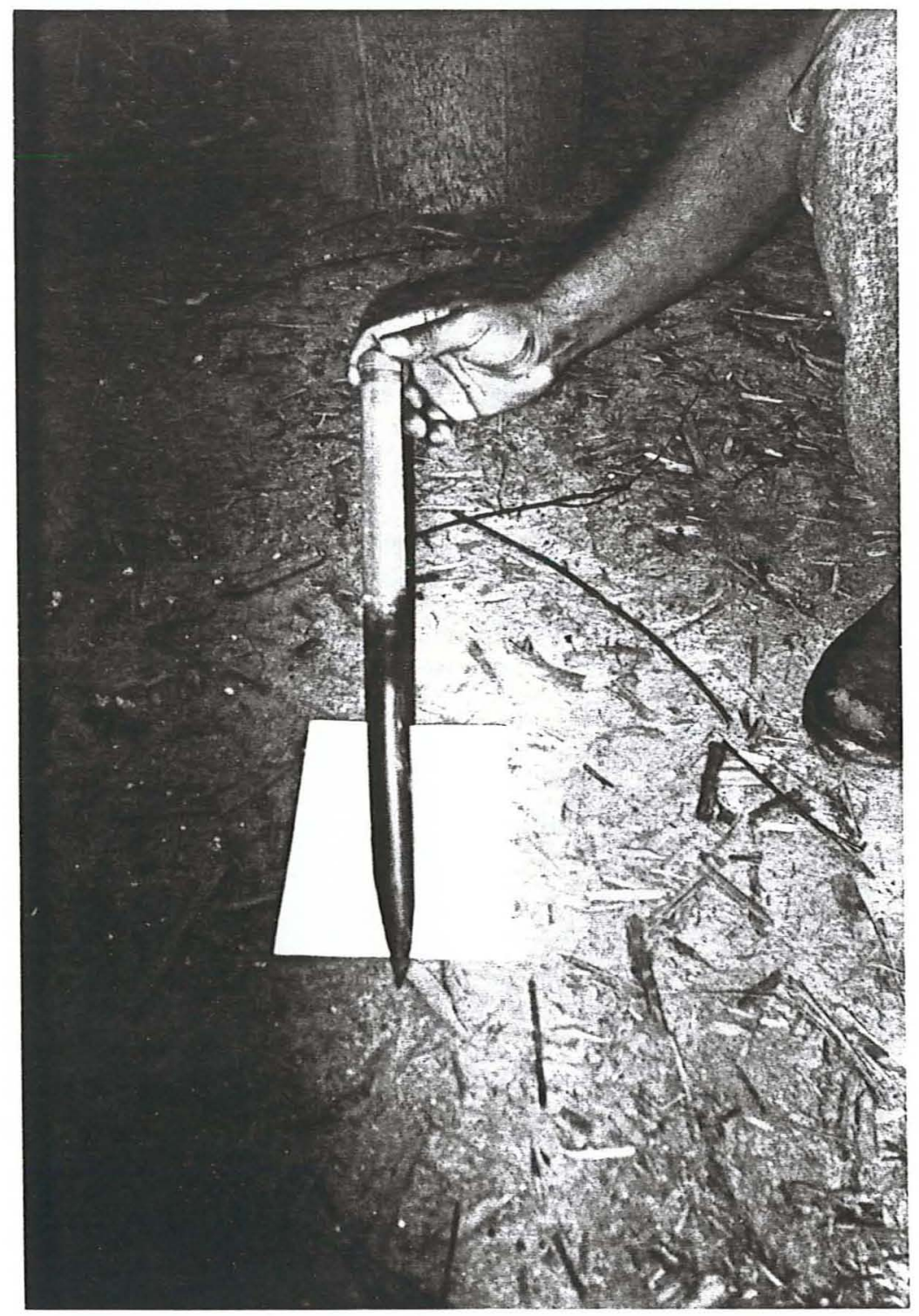

Figura 7. Estaca de bambu utilizada na fixação dos Tratamentos B e C no talude. 


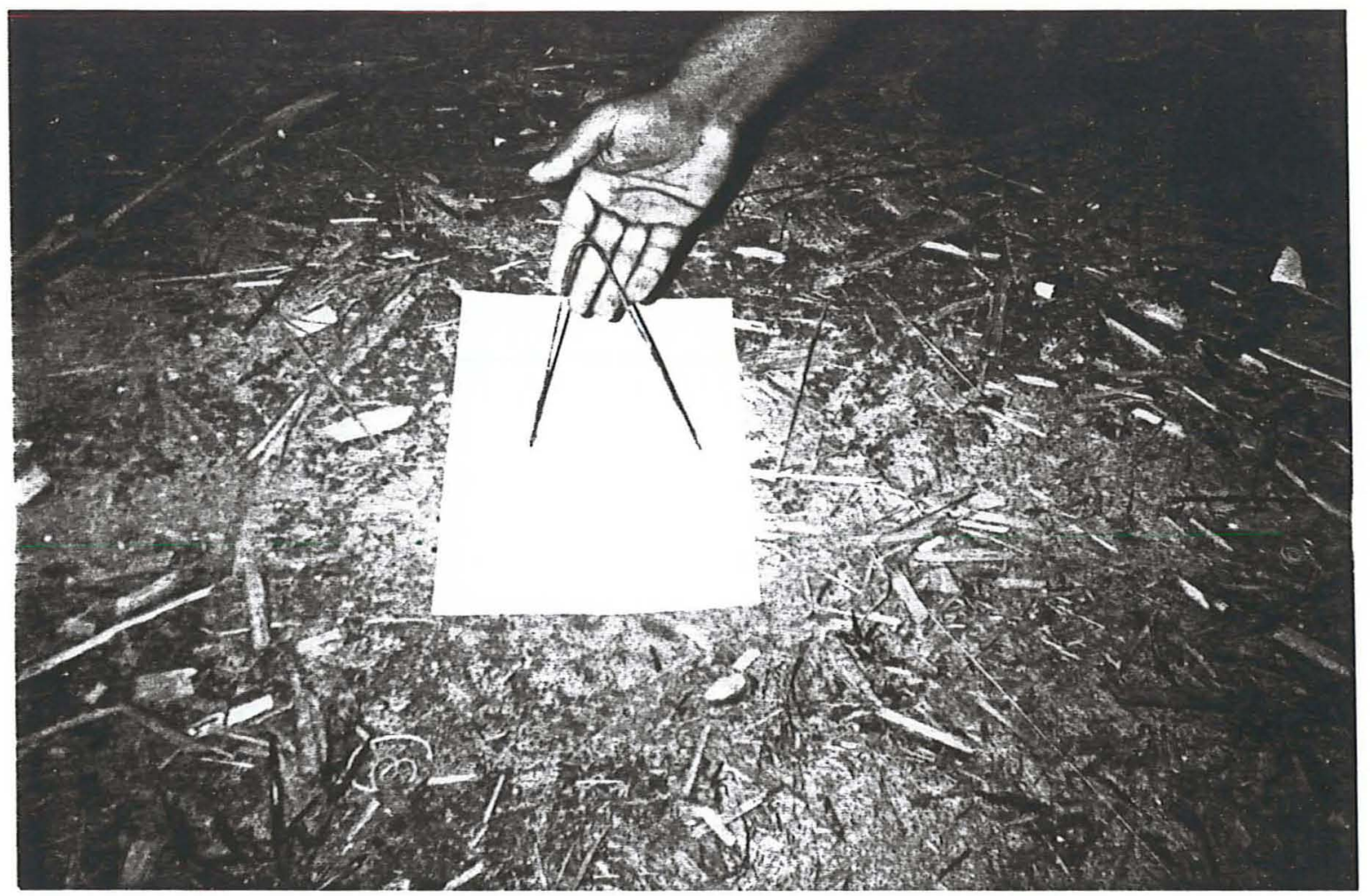

Figura 8. Grampo utilizado para fixação do Tratamento D no talude.

As coletas do material depositado nos baldes plásticos foram feitas de acordo com a periodicidade das chuvas. Primeiramente retirava-se uma amostra de 1 litro, que era levada para as análises laboratoriais, juntamente com uma amostra da água contida no pluviômetro. Depois coletava-se e media-se o volume de toda a água que estava dentro do recipiente (incluindo a amostra coletada), utilizando para isso um balde graduado. Os sedimentos depositados no fundo do recipiente foram coletados para o cálculo da quantidade de sedimentos pesados. 


\subsubsection{Parâmetros físicos e químicos}

As amostras de água foram coletadas em garrafas de polietileno, que eram lavadas em laboratório com solução de $\mathrm{HCl} 10 \%$ e enxaguadas diversas vezes com água corrente e água destilada.

Os frascos eram armazenados em geladeira e transportados para o Laboratório de Ecologia Aplicada do Departamento de Ciências Florestais, da Escola Superior de Agricultura "Luiz de Queiroz" (ESALQ/USP), onde foram feitas as seguintes determinações: sólidos em suspensão, $\mathrm{pH}$, alcalinidade, cor, turbidez e condutividade elétrica.

As análises foram feitas de acordo com as normas da American Public Health Association (1976). A turbidez e a cor foram determinadas utilizando-se um espectrofotômetro $\mathrm{DR} 2000-\mathrm{HACH}$, e a condutividade elétrica, um condutivímetro HACH. O pH foi determinado pelo método potenciométrico, com um pHâmetro modelo 3020 Jenway, e a alcalinidade foi obtida por titulação com ácido sulfúrico $0,02 \mathrm{~N}$.

\subsubsection{Sedimentometria}

A concentração de sedimentos em suspensão foi obtida de uma alíquota de $300 \mathrm{ml}$ de amostra, a qual foi filtrada utilizando-se membrana em éster de celulose com poros de $0,45 \mu \mathrm{m}$, previamente seca em estufa a $105^{\circ} \mathrm{C}$ durante 24 horas e pesada em uma balança analítica. Após a filtragem, a membrana foi seca em estufa do mesmo modo que anteriormente e pesada. A perda de solo proveniente dos sedimentos em suspensão foi calculada através da seguinte fórmula:

$$
\mathrm{C}_{\mathrm{s}}=\left(\mathrm{P}_{\mathrm{f}}-\mathrm{P}_{\mathrm{i}}\right) \times 3333,3
$$

onde, 
$\mathrm{C}_{\mathrm{S}} \rightarrow$ concentração de sedimentos em suspensão (mg/l);

$\mathrm{P}_{\mathrm{f}} \rightarrow$ peso da membrana incluindo os sedimentos;

$\mathrm{P}_{\mathrm{i}} \rightarrow$ peso da membrana.

Os sedimentos depositados no fundo do recipiente (os chamados sedimentos pesados) foram determinados através da secagem em estufa a $105^{\circ} \mathrm{C}$ durante 24 horas e posterior pesagem. Houve recipientes onde a quantidade destes sedimentos não era suficiente para ser coletada (especialmente nos tratamentos grama, casca e tela vegetal). Nestes casos, esperou-se acumular uma quantidade de sedimentos que permitisse a coleta.

A concentração dos sedimentos em suspensão, juntamente com os sedimentos pesados, foram os parâmetros principais de análise e escolha do melhor tratamento no controle da erosão nos taludes de estradas florestais. Os demais $(\mathrm{pH}$, alcalinidade, cor, turbidez e condutividade elétrica) atuaram como coadjuvantes no processo. A perda total de solo dos taludes por erosão foi calculada a partir da soma da concentração de sedimentos em suspensão com a quantidade de sedimentos pesados em cada tratamento.

\subsubsection{Avaliação da taxa de cobertura das parcelas}

A taxa de cobertura das parcelas foi avaliada mensalmente, correlacionando-a com a diminuição da sedimentação. Para isso, cada parcela foi dividida em quadrados de 0,5 m de lado, avaliando-se a cobertura de cada um. Foi considerado suficientemente coberto o quadrado com mais de $50 \%$ de cobertura, extrapolando-se para a área total da parcela. 


\subsubsection{Avaliação econômica}

$\mathrm{Na}$ escolha da melhor cobertura do solo no controle da erosão foi também realizada uma avaliação econômica dos tratamentos, pelo cálculo do custo de cada tratamento, tanto no caso específico do experimento como em uma simulação dos custos de instalação em uma área de 1 hectare. 


\section{RESULTADOS E DISCUSSÃO}

Os resultados obtidos estão contidos nas tabelas e gráficos a seguir. Deve ser ressaltado que o tratamento D (tela vegetal) foi instalado no mês de março, assim, não existem dados para este tratamento nas seis primeiras coletas, correspondentes aos dois primeiros meses do experimento.

\subsection{Taxa de cobertura dos tratamentos}

Os tratamentos casca e tela vegetal apresentaram taxa de recobrimento máxima em todas as avaliações, ao contrário da grama. Nota-se na Figura 9 que a partir do mês de junho, quando a taxa de cobertura deste tratamento atingiu $95 \%$ (considerada um ótimo índice de cobertura do terreno para a grama "Batatais"), a produção de sedimentos mostrou uma estabilização em valores que variaram entre 0,03 e $0,14 \mathrm{t} / \mathrm{ha}$. 


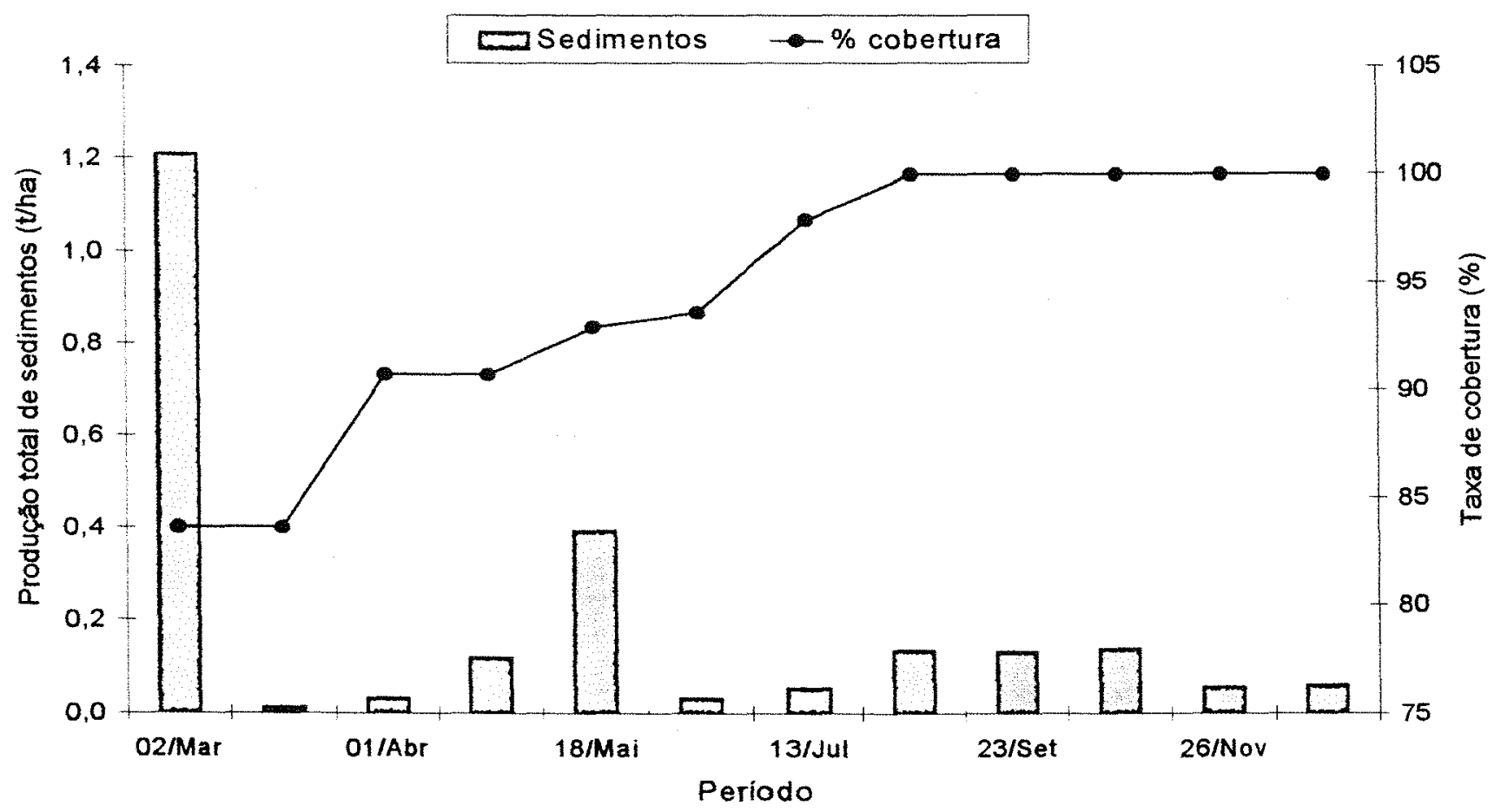

Figura 9. Comparação entre a taxa de cobertura e a produção de sedimentos para 0 Tratamento B (grama).

\subsection{Produção de sedimentos e escoamento superficial}

Pode-se observar na Tabela 11 que a produção de sedimentos pesados na parcela testemunha é muito superior às quantidades produzidas nos demais tratamentos. Entre as coberturas empregadas, a grama foi a que apresentou a maior perda deste tipo de sedimentos, notadamente nos primeiros meses do experimento, quando sua taxa de cobertura nas parcelas era baixa. A casca produziu a menor quantidade de sedimentos pesados. 
Tabela 11. Produção média de sedimentos pesados em $\mathrm{t} / \mathrm{ha}$.

\begin{tabular}{ccccc}
\hline Período & Testemunha & Grama & Casca & Tela \\
\hline 1 - 21 Jan/99 & 6,99 & 0,09 & 0,00 & - \\
$21 \mathrm{Jan}-2 \mathrm{Fev}$ & 3,09 & 2,71 & 0,00 & - \\
$2-8 \mathrm{Fev}$ & 16,41 & 0,42 & 0,00 & - \\
$8-12 \mathrm{Fev}$ & 11,81 & 0,56 & 0,00 & - \\
$12-23 \mathrm{Fev}$ & 2,83 & 0,38 & 0,00 & - \\
$23 \mathrm{Fev}-2 \mathrm{Mar}$ & 3,95 & 0,51 & 0,00 & - \\
$2-18 \mathrm{Mar}$ & 0,00 & 0,00 & 0,00 & 0,00 \\
$18 \mathrm{Mar}-1 \mathrm{Abr}$ & 1,42 & 0,00 & 0,00 & 0,00 \\
$1-20 \mathrm{Abr}$ & 0,00 & 0,00 & 0,00 & 0,00 \\
$20 \mathrm{Abr}-18 \mathrm{Mai}$ & 0,00 & 0,00 & 0,00 & 0,00 \\
$18 \mathrm{Mai}-9 \mathrm{Jun}$ & 0,00 & 0,00 & 0,00 & 0,00 \\
$9 \mathrm{Jun}-13 \mathrm{Jul}$ & 0,00 & 0,00 & 0,00 & 0,00 \\
$13 \mathrm{Jul}-2 \mathrm{Set}$ & 0,35 & 0,05 & 0,02 & 0,09 \\
$2-23 \mathrm{Set}$ & 0,53 & 0,00 & 0,00 & 0,00 \\
23 Set - 18 Out & 0,00 & 0,00 & 0,00 & 0,00 \\
18 Out - 26 Nov & 0,00 & 0,00 & 0,00 & 0,00 \\
26 Nov - 5 Jan/00 & 0,01 & 0,00 & 0,00 & 0,00 \\
\hline Subtotal & 2,31 & 0,05 & 0,02 & 0,09 \\
\hline Total & 47,39 & 4,72 & 0,02 & 0,09 \\
\hline
\end{tabular}

${ }^{1}$ Refere-se à soma dos sedimentos produzidos somente nas coletas onde todos os tratamentos estavam presentes.

Como pode ser notado na Tabela 12 , a produção de sedimentos em suspensão no tratamento A (testemunha) também supera as quantidades produzidas nos demais tratamentos, mas os valores não diferem tanto como no caso dos sedimentos pesados. Os valores correspondentes aos tratamentos B (grama) e D (tela vegetal) são próximos, e, assim como no caso dos sedimentos pesados, a produção de sedimentos em suspensão foi menor no tratamento $\mathrm{C}$ (casca). Observando-se somente a produção de sedimentos 
em suspensão nos dois primeiros meses do experimento, quando a tela ainda não estava instalada, nota-se que esta foi maior na grama, superando até mesmo a perda da parcela descoberta. Isso ocorreu porque, neste início, a maior parte dos sedimentos perdidos pela testemunha correspondeu às maiores particulas, que depositavam-se no fundo do recipiente de coleta e eram contabilizadas como sedimentos pesados.

Tabela 12. Produção média de sedimentos em suspensão em $\mathrm{t} / \mathrm{ha}$.

\begin{tabular}{ccccc}
\hline Periodo & Testemunha & Grama & Casca & Tela \\
\hline 1 - 21 Jan/99 & 0,1 & 0,15 & 0,16 & - \\
$21 \mathrm{Jan}-2 \mathrm{Fev}$ & 0,1 & 0,25 & 0,01 & - \\
$2-8 \mathrm{Fev}$ & 0,14 & 0,11 & 0,02 & - \\
$8-12 \mathrm{Fev}$ & 0,05 & 0,12 & 0,03 & - \\
$12-23 \mathrm{Fev}$ & 0,65 & 0,47 & 0,31 & - \\
$23 \mathrm{Fev}-2 \mathrm{Mar}$ & 0,23 & 0,64 & 0,06 & - \\
$2-18 \mathrm{Mar}$ & 0,14 & 0,01 & 0,01 & 0,08 \\
$18 \mathrm{Mar}-1 \mathrm{Abr}$ & 0,05 & 0,03 & 0,02 & 0,07 \\
$1-20 \mathrm{Abr}$ & 0,08 & 0,12 & 0,04 & 0,1 \\
$20 \mathrm{Abr}-18 \mathrm{Mai}$ & 0,63 & 0,39 & 0,04 & 0,55 \\
$18 \mathrm{Mai}-9 \mathrm{Jun}$ & 0,15 & 0,03 & 0,01 & 0,02 \\
9 Jun - 13 Jul & 0,31 & 0,05 & 0,04 & 0,08 \\
$13 \mathrm{Jul}-2 \mathrm{Set}$ & 0,07 & 0,09 & 0,05 & 0,02 \\
$2-23 \mathrm{Set}$ & 0,71 & 0,13 & 0,02 & 0,24 \\
23 Set - 18 Out & 0,47 & 0,14 & 0,02 & 0,25 \\
18 Out - 26 Nov & 0,55 & 0,06 & 0,02 & 0,38 \\
26 Nov-5 Jan/00 & 1,25 & 0,15 & 0,10 & 0,30 \\
\hline Subtotal & 4,41 & 1,74 & 0,37 & 2,09 \\
\hline Total & 5,68 & 2,94 & 0,96 & 2,09 \\
\hline
\end{tabular}

${ }^{1}$ Refere-se à soma dos sedimentos produzidos somente nas coletas onde todos os tratamentos estavam presentes. 
Tabela 13. Produção total de sedimentos em t/ha.

\begin{tabular}{ccccc}
\hline Periodo & Testemunha & Grama & Casca & Tela \\
\hline $1-21 \mathrm{Jan} / 99$ & 7,09 & 0,24 & 0,16 & - \\
$21 \mathrm{Jan}-2 \mathrm{Fev}$ & 3,19 & 2,96 & 0,01 & - \\
$2-8 \mathrm{Fev}$ & 16,55 & 0,53 & 0,02 & - \\
$8-12 \mathrm{Fev}$ & 11,86 & 0,68 & 0,03 & - \\
$12-23 \mathrm{Fev}$ & 3,48 & 0,85 & 0,31 & - \\
$23 \mathrm{Fev}-2 \mathrm{Mar}$ & 4,18 & 1,15 & 0,06 & - \\
$2-18 \mathrm{Mar}$ & 0,14 & 0,01 & 0,01 & 0,10 \\
$18 \mathrm{Mar}-1 \mathrm{Abr}$ & 1,47 & 0,03 & 0,02 & 0,10 \\
$1-20 \mathrm{Abr}$ & 0,08 & 0,12 & 0,04 & 0,10 \\
$20 \mathrm{Abr}-18 \mathrm{Mai}$ & 0,63 & 0,39 & 0,04 & 0,55 \\
$18 \mathrm{Mai}-9 \mathrm{Jun}$ & 0,14 & 0,03 & 0,01 & 0,02 \\
$9 \mathrm{Jun}-13 \mathrm{Jul}$ & 0,31 & 0,05 & 0,04 & 0,10 \\
$13 \mathrm{Jul}-2 \mathrm{Set}$ & 0,42 & 0,14 & 0,07 & 0,40 \\
2-23 Set & 1,24 & 0,13 & 0,02 & 0,20 \\
23 Set - 18 Out & 0,47 & 0,14 & 0,02 & 0,20 \\
18 Out - 26 Nov & 0,56 & 0,06 & 0,02 & 0,40 \\
26 Nov - 5 Jan/00 & 1,26 & 0,15 & 0,10 & 0,10 \\
\hline Subtotal & 6,72 & 1,25 & 0,39 & 2,27 \\
\hline Total & 53,07 & 7,66 & 0,98 & 2,27 \\
\hline
\end{tabular}

${ }^{1}$ Refere-se à soma dos sedimentos produzidos somente nas coletas onde todos os tratamentos estavam presentes.

Observando-se a Tabela 13 percebe-se que a quantidade total de sedimentos produzida na testemunha foi bastante superior aos outros tratamentos. Nota-se que aproximadamente $87 \%$ da produção de sedimentos deste tratamento ocorreram nos dois primeiros meses do experimento (até a coleta 6 ). Entre as coberturas analisadas, a grama produziu a maior quantidade total de sedimentos, considerando-se todas as coletas feitas. Neste caso também a maior parte dos sedimentos (aproximadamente $83 \%$ ) foi produzida 
nos dois primeiros meses do experimento, quando a grama ainda não havia coberto satisfatoriamente a área da parcela. De acordo com a classificação de Sequera (1989), que pode ser observada na Tabela 1, a perda de solo na testemunha é alta. Já as perdas de sedimentos dos demais tratamentos é considerada nula. Levando-se em consideração apenas a perda de sedimentos do dia dois de março em diante, quando todos os tratamentos haviam sido instalados, a tela vegetal apresentou os maiores valores entre as coberturas estudadas. A casca levou vantagem sobre os demais em ambas as situações, pois reduziu a produção de sedimentos, comparativamente à testemunha, em 92,5\%, em média. Grama e tela vegetal reduziram em $69,3 \%$ e $54,1 \%$, respectivamente. As Figuras 10 e 11 ilustram melhor estes dados.

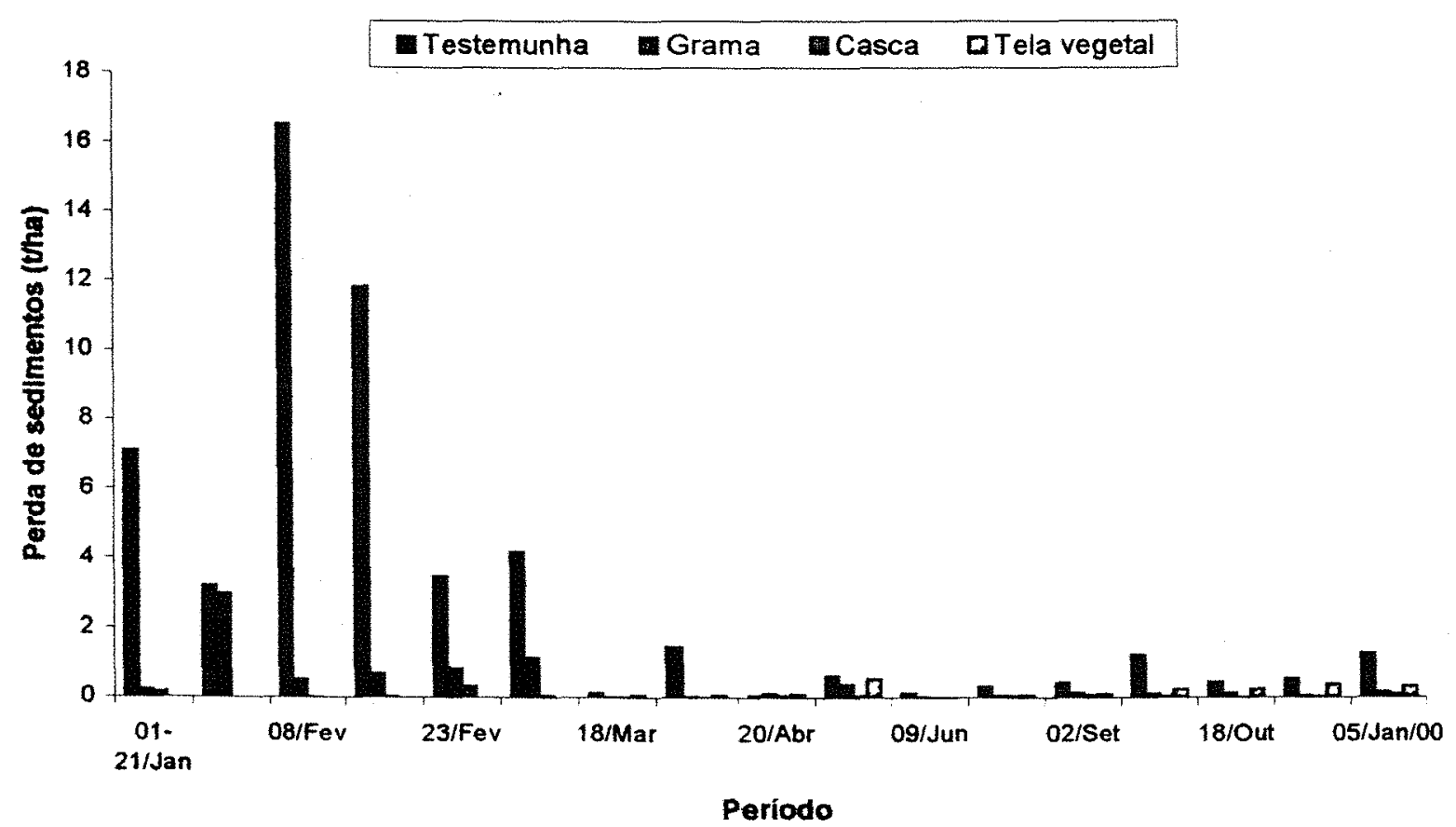

Figura 10. Produção total de sedimentos em $\mathrm{t} /$ ha para os tratamentos analisados. 


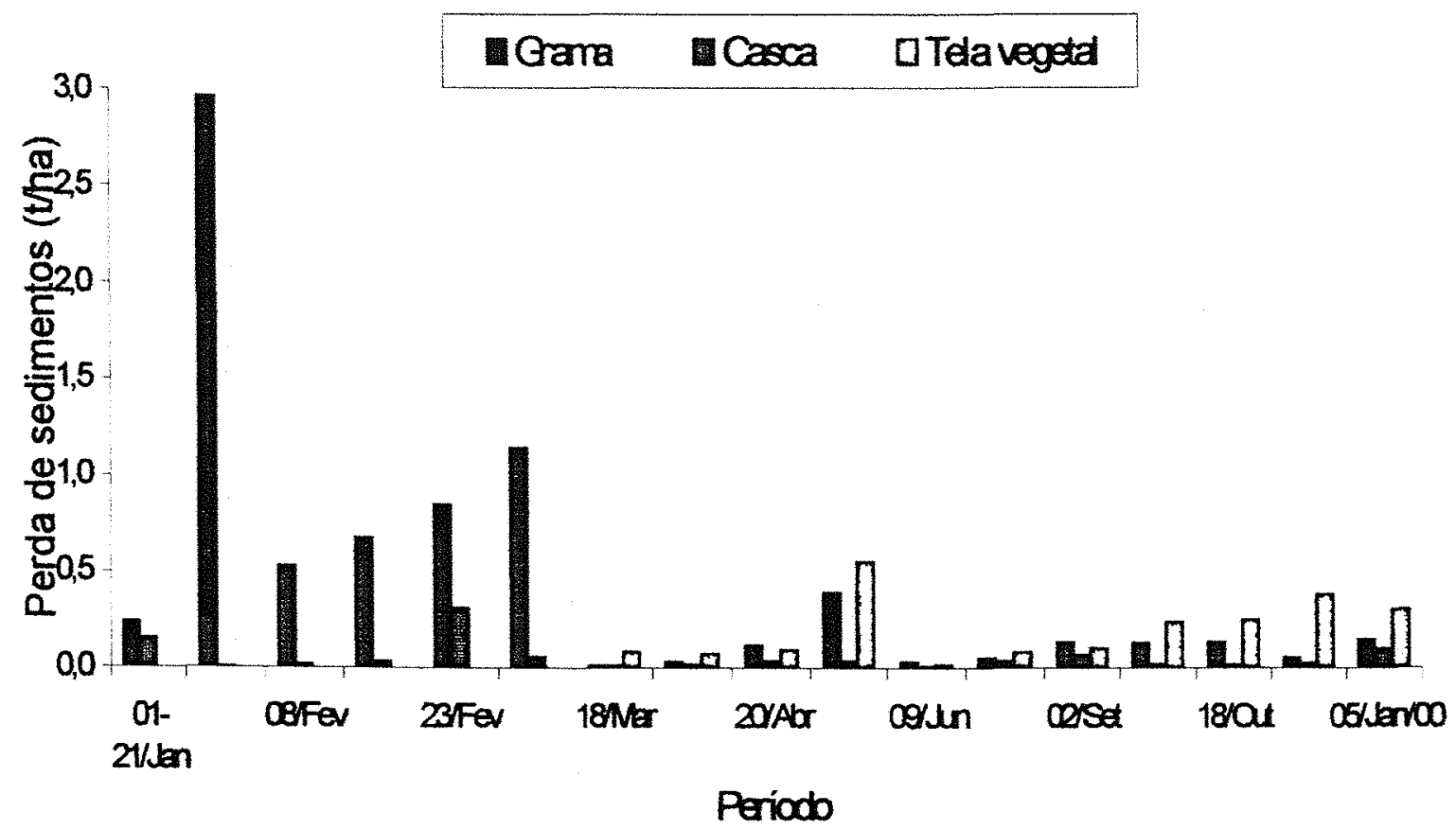

Figura 11. Produção total de sedimentos para os Tratamentos B (grama), C (casca) e $\mathrm{D}$ (tela vegetal). 
Tabela 14. Escoamento superficial, em $\mathrm{mm}$, para os tratamentos analisados.

\begin{tabular}{ccccc}
\hline Periodo & Testemunha & Grama & Casca & Tela \\
\hline 1 - 21 Jan/99 & 5,40 & 24,00 & 5,00 & - \\
21 Jan - 2 Fev & 4,20 & 31,90 & 0,00 & - \\
$2-8 \mathrm{Fev}$ & 6,00 & 44,00 & 19,30 & - \\
$8-12 \mathrm{Fev}$ & 4,90 & 35,40 & 52,90 & - \\
$12-23 \mathrm{Fev}$ & 5,90 & 84,90 & 99,70 & - \\
$23 \mathrm{Fev}-2 \mathrm{Mar}$ & 8,10 & 99,90 & 110,70 & - \\
$2-18 \mathrm{Mar}$ & 0,70 & 17,00 & 33,60 & 5,40 \\
$18 \mathrm{Mar}-1 \mathrm{Abr}$ & 5,20 & 49,90 & 77,60 & 36,40 \\
$1-20 \mathrm{Abr}$ & 72,60 & 95,70 & 110,00 & 70,60 \\
20 Abr - 18 Mai & 10,10 & 8,30 & 17,30 & 11,10 \\
18 Mai - 9 Jun & 4,30 & 7,30 & 11,60 & 7,60 \\
9 Jun - 13 Jul & 55,70 & 59,40 & 93,00 & 53,00 \\
13 Jul - 2 Set & 12,30 & 3,30 & 5,10 & 6,00 \\
2-23 Set & 60,10 & 50,70 & 87,10 & 36,70 \\
23 Set - 18 Out & 12,40 & 15,60 & 37,00 & 16,30 \\
18 Out - 26 Nov & 19,40 & 28,70 & 38,30 & 19,70 \\
26 Nov - 5 Jan/00 & 71,70 & 88,30 & 116,10 & 58,70 \\
\hline Subtotal & 324,50 & 424,20 & 626,70 & 321,50 \\
\hline Total & 359,00 & 744,30 & 914,30 & 321,50 \\
\hline
\end{tabular}

${ }^{1}$ Refere-se ao total do escoamento superficial produzido somente nas coletas onde todos os tratamentos estavam presentes.

Estes valores estão ilustrados na Figura 12. 


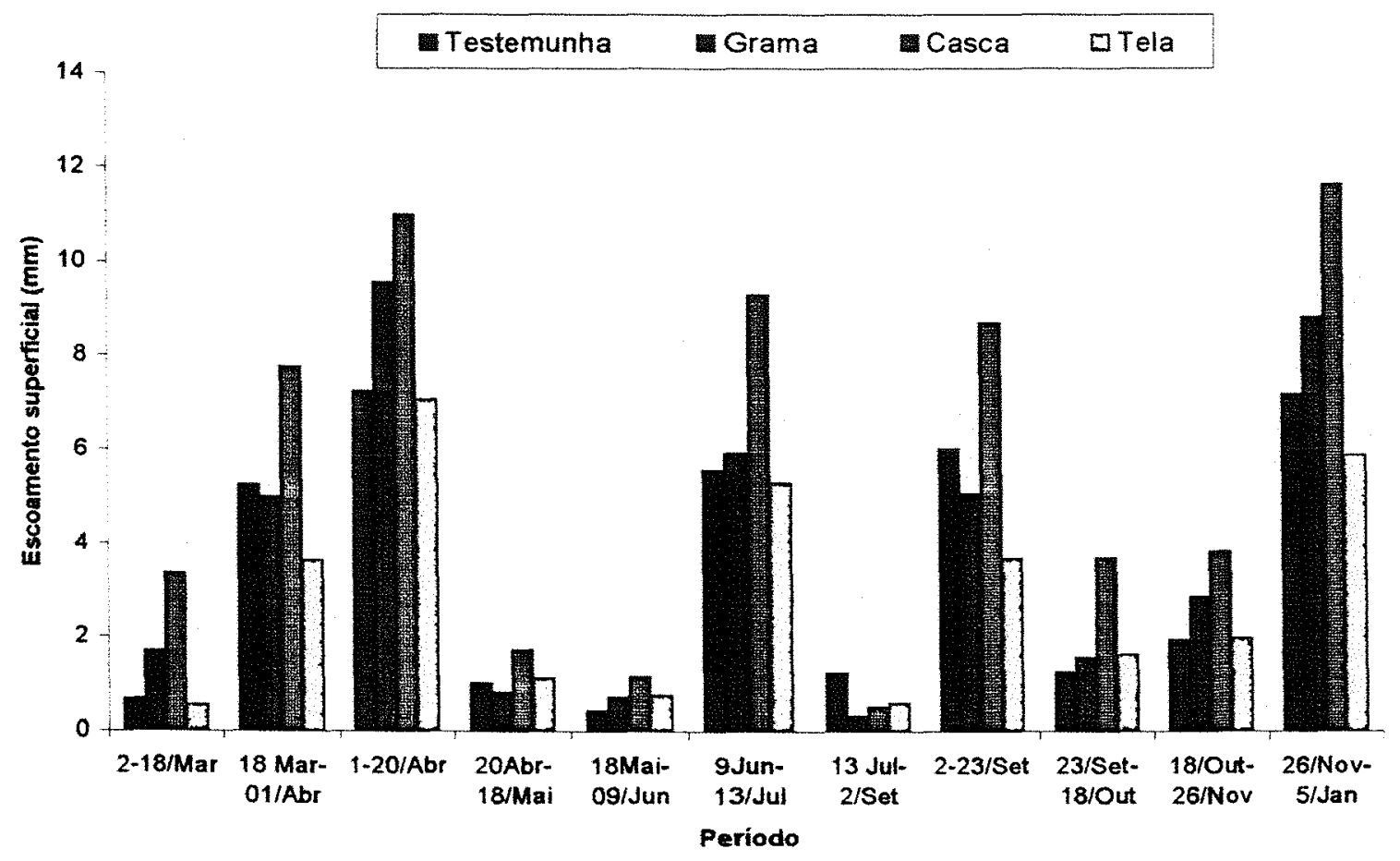

Figura 12. Escoamento superficial, em mm, para os tratamentos analisados. 
Tabela 15. Escoamento superficial em relação à precipitação (\%) para os tratamentos analisados.

\begin{tabular}{|c|c|c|c|c|}
\hline Período & Testemunha & Grama & Casca & Tela \\
\hline $1-21 \mathrm{Jan} / 99$ & 2,35 & 1,05 & 0,22 & - \\
\hline $21 \mathrm{Jan}-2 \mathrm{Fev}$ & 5,67 & 4,33 & 0,00 & - \\
\hline $2-8 \mathrm{Fev}$ & 7,39 & 5,39 & 2,36 & - \\
\hline $8-12 \mathrm{FeV}$ & 9,58 & 6,95 & 10,36 & - \\
\hline $12-23 \mathrm{Fev}$ & 8,63 & 12,44 & 14,62 & - \\
\hline $23 \mathrm{Fev}-2 \mathrm{Mar}$ & 7,40 & 9,14 & 10,14 & - \\
\hline $2-18 \mathrm{Mar}$ & 2,03 & 5,03 & 9,93 & 1,61 \\
\hline $18 \mathrm{Mar}-1 \mathrm{Abr}$ & 7,90 & 7,51 & 11,68 & 5,49 \\
\hline $1-20 \mathrm{Abr}$ & 6,20 & 8,18 & 9,40 & 6,03 \\
\hline $20 \mathrm{Abr}-18 \mathrm{Mai}$ & 4,33 & 3,54 & 7,39 & 4,76 \\
\hline $18 \mathrm{Mai}-9$ Jun & 3,11 & 5,28 & 8,39 & 5,49 \\
\hline 9 Jun -13 Jul & 6,25 & 6,66 & 10,43 & 5,94 \\
\hline $13 \mathrm{Jul}-2$ Set & 19,20 & 5,13 & 8,04 & 9,38 \\
\hline $2-23$ Set & 8,69 & 7,33 & 12,59 & 5,31 \\
\hline 23 Set -18 Out & 3,79 & 4,75 & 11,28 & 4,97 \\
\hline 18 Out $-26 \mathrm{Nov}$ & 2,68 & 3,97 & 5,29 & 2,72 \\
\hline $26 \mathrm{Nov}-5 \mathrm{Jan} / 00$ & 4,06 & 5,00 & 6,58 & 3,32 \\
\hline Média & 6,43 & 5,98 & 8,16 & 5,00 \\
\hline
\end{tabular}

Através das Tabelas 14 e 15 observa-se que a casca apresentou os maiores valores de escoamento superficial total $(\mathrm{mm})$ e escoamento superficial em relação à precipitação (\%). Apesar disso, pela Tabela 13 percebe-se que neste tratamento a perda de sedimentos foi menor. Isto aconteceu provavelmente porque a maior parte do escoamento se deu entre o solo e a casca, e como esta é uma cobertura morta, ela não consumiu nem reteve a água, mas funcionou como uma barreira ao deslocamento dos sedimentos. 


\subsection{Parâmetros de qualidade da água}

Os parâmetros de qualidade da água foram mensurados também para a água da chuva contida no pluviômetro, a título de comparação. Os valores referentes a esta amostragem servirão de referência para os tratamentos analisados (Tabela 16).

Tabela 16. Parâmetros de qualidade para a água da chuva.

\begin{tabular}{cccccc}
\hline Periodo & $\begin{array}{c}\text { Cor } \\
(\text { PtCo })\end{array}$ & $\begin{array}{c}\text { Condutiv. } \\
(\mathrm{mS} / \mathrm{cm})\end{array}$ & $\begin{array}{c}\text { Turbidez } \\
(\mathrm{FTU})\end{array}$ & $\begin{array}{c}\text { Alcalin. } \\
(\mathrm{mg} / \mathrm{L})\end{array}$ & $\mathrm{pH}$ \\
\hline 2 - 18 Mar & 9,0 & 0,07 & 6,0 & 0,1 & 6,5 \\
18 Mar - 1 Abr & 19,0 & 0,05 & 3,0 & 0,2 & 6,4 \\
1-20 Abr & 0,0 & 0,1 & 3,0 & 0,0 & 3,2 \\
20 Abr - 18 Mai & 6,0 & 0,2 & 6,0 & 0,0 & 3,2 \\
18 Mai - 9 Jun & 26,0 & 0,1 & 19,0 & 0,0 & 4,2 \\
9 Jun - 13 Jul & 7,0 & 0,1 & 7,0 & 9,5 & 6,5 \\
13 Jul - 2 Set & 20,0 & 0,2 & 65,0 & 0,0 & 2,6 \\
2-23 Set & 15,0 & 0,2 & 4,0 & 0,0 & 3,4 \\
23 Set - 18 Out & 20,0 & 0,1 & 15,0 & 11,2 & 7,0 \\
18 Out - 26 Nov & 0,0 & 0,1 & 2,0 & 4,8 & 5,7 \\
26 Nov - 5 Jan/00 & 14,0 & 0,1 & 3,0 & 2,0 & 6,7 \\
\hline Média & 12,4 & 0,2 & 12,1 & 2,5 & 5,0 \\
\hline
\end{tabular}

A cor indica principalmente a presença de material orgânico. Em comparação com os valores da água da chuva (Tabela 16), em todos os casos estudados os valores de cor podem ser considerados altos. A partir da Tabela 17 e da Figura 13 percebe-se que os maiores valores de cor ocorreram nos tratamentos $\mathrm{C}$ (casca) e D (tela vegetal), devido à lavagem da matéria orgânica presente na casca e na tela vegetal. Isto ocorreu também no caso do tratamento B (grama), porém, em menor quantidade. O tratamento A (testemunha) apresentou os menores valores relativos à cor, devido ao fato de que a 
maior parte dos sedimentos produzidos era de sedimentos pesados, que ficavam depositados no fundo do recipiente e não interferiam na medição da cor.

Tabela 17. Valores médios de cor ( $\mathrm{PtCo})$ para os tratamentos analisados.

\begin{tabular}{ccccc}
\hline Período & Testemunha & Grama & Casca & Tela \\
\hline 1 - 21 Jan/99 & 15,8 & 24,0 & 289,5 & - \\
21 Jan - 2 Fev & 48,4 & 374,3 & 230,0 & - \\
2 - 8 Fev & 189,0 & 236,2 & 317,5 & - \\
$8-12 \mathrm{Fev}$ & 172,8 & 307,0 & 550,0 & - \\
12 - 23 Fev & 46,0 & 273,2 & 472,8 & - \\
23 Fev - 2 Mar & 55,4 & 456,4 & 374,8 & - \\
2 - 18 Mar & 47,8 & 203,6 & 304,5 & 227,5 \\
18 Mar - 1 Abr & 50,0 & 304,8 & 287,0 & 415,4 \\
1 - 20 Abr & 45,4 & 196,4 & 172,8 & 481,8 \\
20 Abr - 18 Mai & 44,6 & 351,8 & 202,0 & 397,0 \\
18 Mai - 9 Jun & 23,3 & 195,4 & 268,8 & 224,0 \\
9 Jun - 13 Jul & 10,8 & 10,8 & 117,0 & 150,6 \\
13 Jul - 2 Set & 70,7 & 198,0 & 377,0 & 312,7 \\
2 - 23 Set & 187,0 & 134,2 & 302,3 & 340,8 \\
23 Set - 18 Out & 203,8 & 203,8 & 270,8 & 199,6 \\
18 Out - 26 Nov & 239,4 & 128,8 & 252,0 & 147,0 \\
26 Nov - 5 Jan/00 & 394,8 & 312,4 & 342,0 & 367,0 \\
\hline Média & 108,5 & 230,1 & 301,8 & 296,7 \\
\hline
\end{tabular}




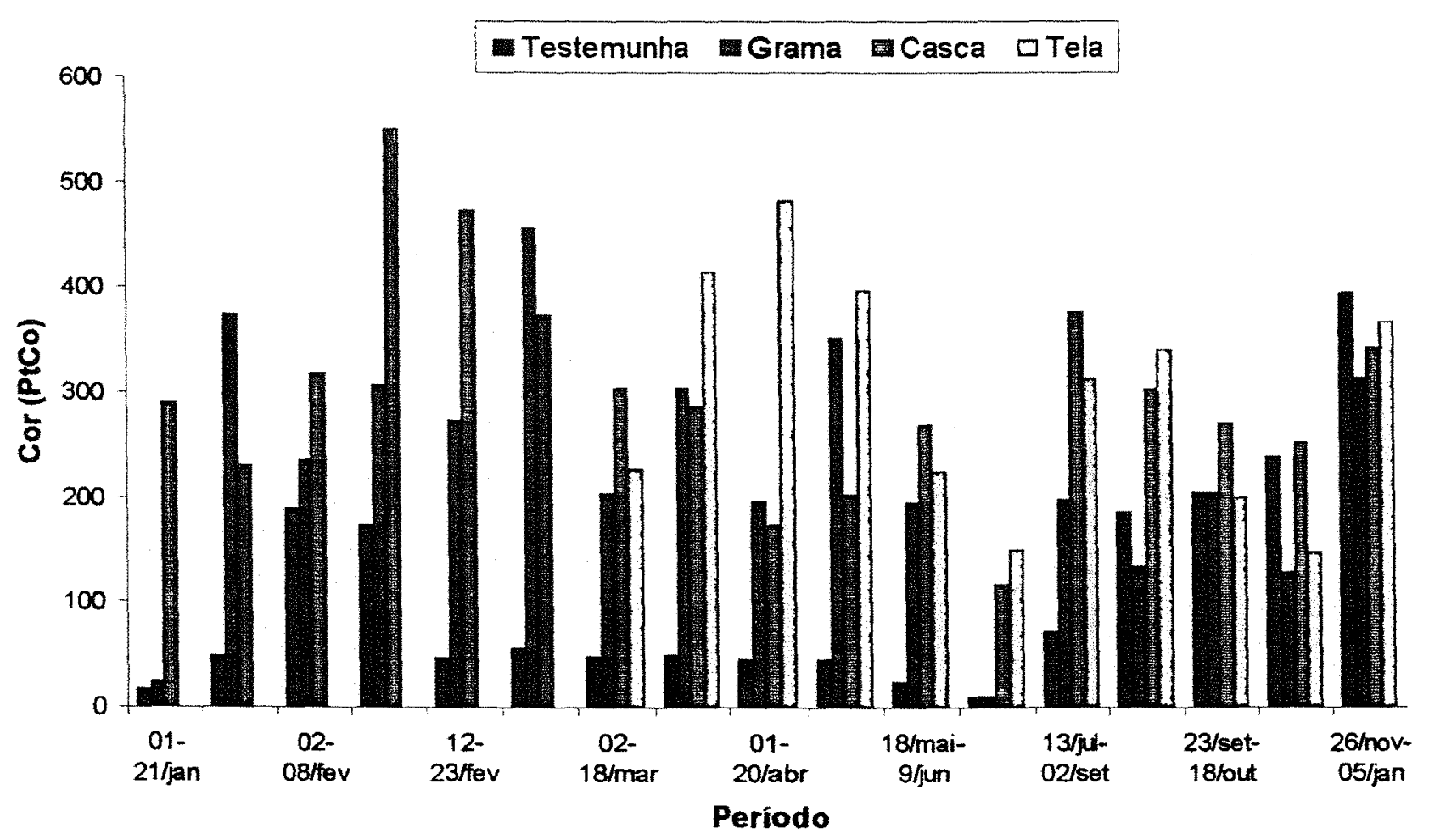

Figura 13. Valores médios de cor ( $\mathrm{PtCo})$ para os tratamentos analisados.

A condutividade elétrica indica a presença de sais dissolvidos na água e que podem conduzir corrente elétrica. Através da Tabela 18 e da Figura 14, pode-se perceber que neste caso os valores dos tratamentos ficaram bem próximos uns dos outros, com um pequeno destaque para o tratamento $D$ (tela vegetal), que apresentou um valor médio ligeiramente maior do que os demais. Os valores obtidos para todos os tratamentos são próximos aos referentes à água da chuva contidos na Tabela 16 . 
Tabela 18. Valores médios de condutividade elétrica $(\mathrm{mS} / \mathrm{cm})$ para os tratamentos analisados.

\begin{tabular}{ccccc}
\hline Período & Testemunha & Grama & Casca & Tela \\
\hline 1 - 21 Jan/99 & 0,38 & 0,10 & 0,10 & - \\
$21 \mathrm{Jan}-2 \mathrm{Fev}$ & 0,10 & 0,10 & 0,20 & - \\
$2-8 \mathrm{Fev}$ & 0,10 & 0,10 & 0,10 & - \\
$8-12 \mathrm{Fev}$ & 0,10 & 0,10 & 0,10 & - \\
$12-23 \mathrm{Fev}$ & 0,10 & 0,10 & 0,10 & - \\
$23 \mathrm{Fev}-2 \mathrm{Mar}$ & 0,10 & 0,10 & 0,10 & - \\
$2-18 \mathrm{Mar}$ & 0,32 & 0,16 & 0,10 & 0,30 \\
$18 \mathrm{Mar}-1 \mathrm{Abr}$ & 0,18 & 0,18 & 0,13 & 0,14 \\
$1-20 \mathrm{Abr}$ & 0,20 & 0,18 & 0,13 & 0,14 \\
20 Abr - 18 Mai & 0,10 & 0,12 & 0,10 & 0,16 \\
$18 \mathrm{Mai}-9 \mathrm{Jun}$ & 0,20 & 0,16 & 0,18 & 0,23 \\
9 Jun - 13 Jul & 0,12 & 0,14 & 0,10 & 0,12 \\
$13 \mathrm{Jul}-2 \mathrm{Set}$ & 0,13 & 0,30 & 0,30 & 0,40 \\
2-23 Set & 0,14 & 0,16 & 0,10 & 0,10 \\
23 Set - 18 Out & 0,10 & 0,10 & 0,10 & 0,12 \\
18 Out - 26 Nov & 0,12 & 0,10 & 0,10 & 0,14 \\
26 Nov - 5 Jan/00 & 0,10 & 0,10 & 0,10 & 0,10 \\
\hline Média & 0,15 & 0,14 & 0,13 & 0,18 \\
\hline
\end{tabular}




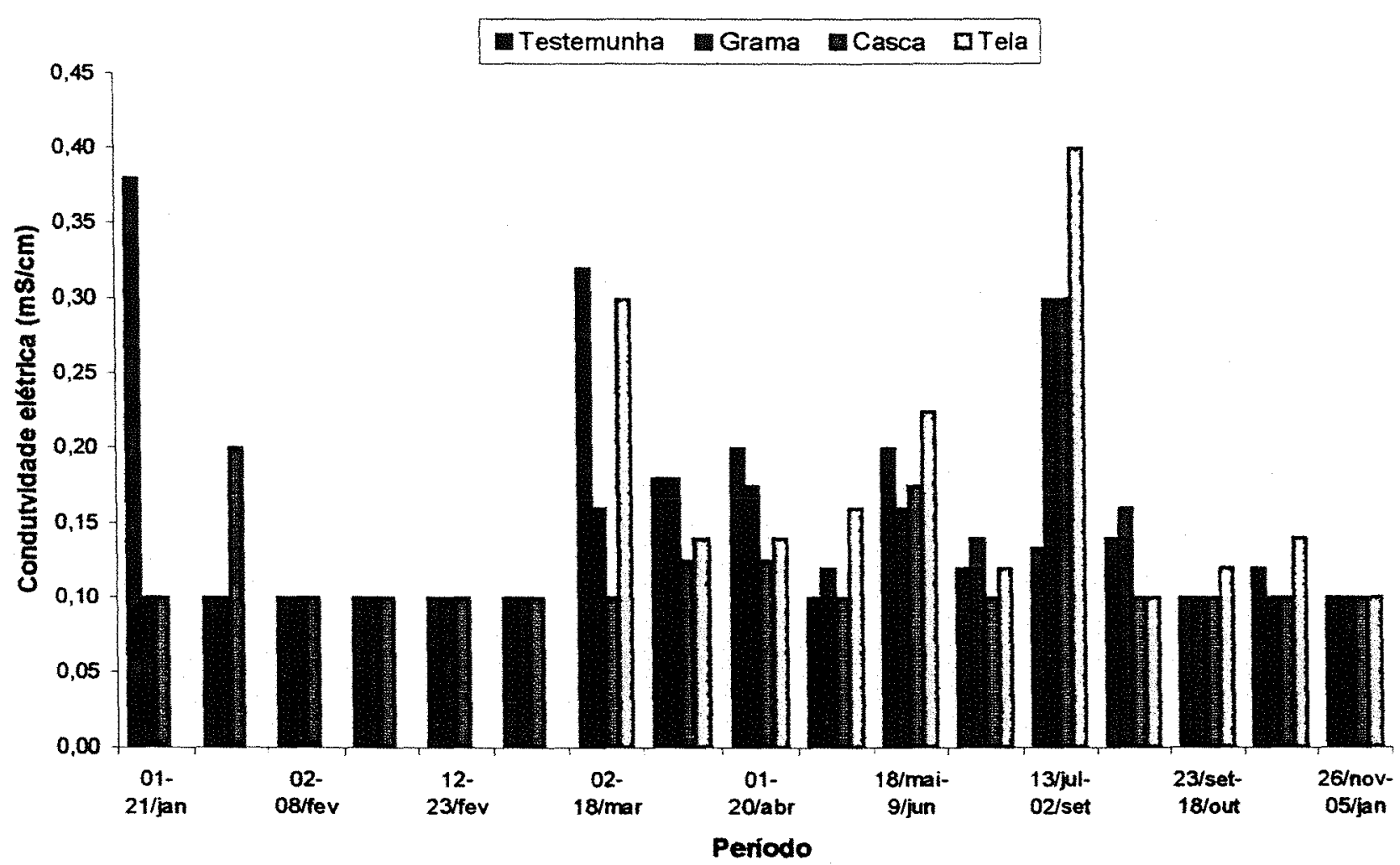

Figura 14. Valores médios de condutividade elétrica $(\mathrm{mS} / \mathrm{cm})$ para os tratamentos analisados.

A medição da turbidez capta as menores partículas em suspensão na água, que são ainda menores do que as que fazem parte dos sedimentos em suspensão. Nos tratamentos analisados os valores de turbidez podem ser considerados altos, muito acima do valor médio da água da chuva, que foi de 12,1 (Tabela 16). Através da Tabela $19 \mathrm{e} \mathrm{da}$ Figura 15, nota-se que o tratamento onde os valores de turbidez foram maiores foi o $\mathrm{A}$ (testemunha), seguido pelo B (grama), D (tela vegetal) e C (casca). Apesar disso, no início do experimento a testemunha apresentou os valores mais baixos de turbidez. Isto pode ser explicado pelo fato de que no início os sedimentos perdidos foram aqueles maiores e mais pesados, que ficavam depositados no fundo do recipiente de coleta e 
eram contabilizados como sedimentos pesados. Com o tempo, quando estes sedimentos já tinham sido perdidos, os valores de turbidez aumentaram, pois começaram a ser perdidos os sedimentos mais finos.

A maneira como foi feita a coleta do material pode ter influenciado nos resultados de turbidez. O ideal teria sido misturar um pouco a água da superficie do recipiente antes de coletar a água, mas neste experimento a coleta foi feita com a água parada, sem a utilização deste procedimento.

Tabela 19. Valores médios de turbidez (FTU) para os tratamentos analisados.

\begin{tabular}{ccccc}
\hline Periodo & Testemunha & Grama & Casca & Tela \\
\hline 1 - 21 Jan/99 & 27,6 & 75,8 & 138,0 & - \\
21 Jan - 2 Fev & 96,6 & 404,3 & 55,0 & - \\
2 - 8 Fev & 152,0 & 210,8 & 104,0 & - \\
$8-12 \mathrm{Fev}$ & 114,6 & 258,6 & 357,5 & - \\
$12-23 \mathrm{Fev}$ & 180,4 & 313,0 & 252,8 & - \\
23 Fev - 2 Mar & 158,4 & 389,2 & 113,3 & - \\
2 - 18 Mar & 169,4 & 62,4 & 83,5 & 167,8 \\
18 Mar - 1 Abr & 104,2 & 87,2 & 63,0 & 142,2 \\
1 - 20 Abr & 67,4 & 153,0 & 46,3 & 167,6 \\
20 Abr - 18 Mai & 416,4 & 398,6 & 113,0 & 346,4 \\
18 Mai - 9 Jun & 298,5 & 82,0 & 92,5 & 95,3 \\
9 Jun - 13 Jul & 286,4 & 83,2 & 60,5 & 97,2 \\
13 Jul - 2 Set & 461,0 & 461,0 & 391,3 & 312,0 \\
2 - 23 Set & 367,2 & 80,8 & 78,0 & 195,6 \\
23 Set - 18 Out & 429,6 & 203,4 & 96,0 & 304,4 \\
18 Out - 26 Nov & 416,2 & 70,0 & 65,8 & 235,8 \\
26 Nov - 5 Jan/00 & 334,8 & 103,8 & 86,5 & 135,4 \\
\hline Média & 240,0 & 202,2 & 129,2 & 200,0 \\
\hline
\end{tabular}




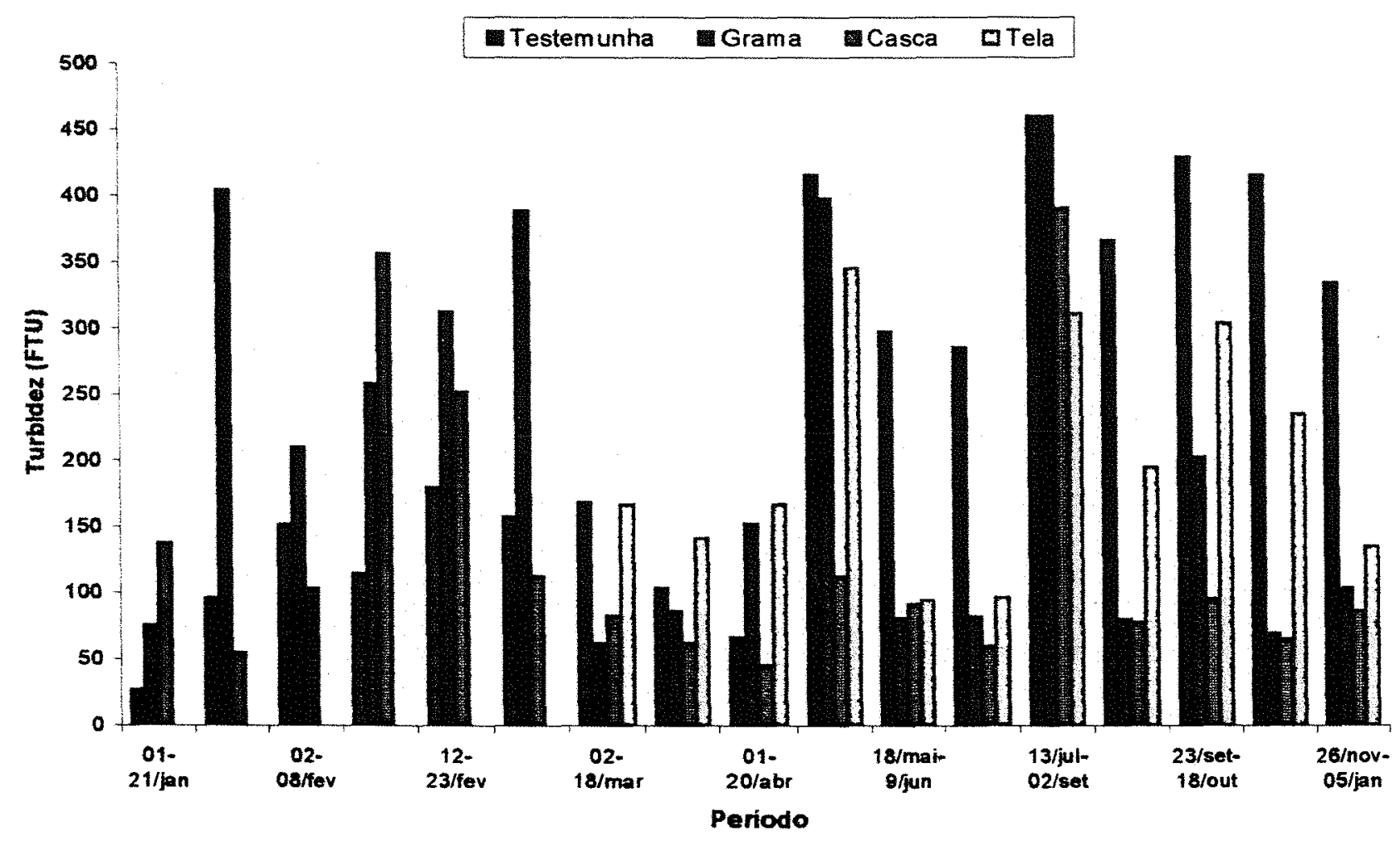

Figura 15. Valores médios de turbidez (FTU) para os tratamentos analisados.

A alcalinidade indica a presença de carbonatos, bicarbonatos e hidróxidos na água, e é uma medida da capacidade que a água apresenta de neutralizar ácidos, ou seja, de absorver íons $\mathrm{H}^{+}$sem que ocorra mudança no $\mathrm{pH}$. Através da Tabela 20 e da Figura 16 percebe-se que os maiores valores de alcalinidade ocorreram no tratamento $\mathrm{D}$ (tela vegetal), superando os demais, que em ordem decrescente foram: $\mathrm{C}$ (casca), B (grama) e A (testemunha). O valor correspondente à testemunha foi o que mais se aproximou do valor referente à água da chuva (média de 2,5) (Tabela 16). 
Tabela 20. Valores médios de alcalinidade $(\mathrm{mg} / \mathrm{L})$ para os tratamentos analisados.

\begin{tabular}{|c|c|c|c|c|}
\hline Período & Testemunha & Grama & Casca & Tela \\
\hline $1-21 \operatorname{Jan} / 99$ & 0,34 & 0,23 & 2,80 & - \\
\hline $21 \mathrm{Jan}-2 \mathrm{Fev}$ & 0,16 & 0,17 & 3,20 & - \\
\hline $2-8 \mathrm{Fev}$ & 0,18 & 0,14 & 0,20 & - \\
\hline $8-12 \mathrm{Fev}$ & 0,14 & 0,16 & 0,25 & - \\
\hline $12-23 \mathrm{Fev}$ & 0,20 & 0,20 & 0,33 & - \\
\hline $23 \mathrm{Fev}$ - $2 \mathrm{Mar}$ & 0,14 & 0,12 & 0,35 & - \\
\hline $2-18 \mathrm{Mar}$ & 0,00 & 0,20 & 0,30 & 4,70 \\
\hline $18 \mathrm{Mar}-1 \mathrm{Abr}$ & 1,30 & 0,55 & 0,50 & 1,84 \\
\hline $1-20 \mathrm{Abr}$ & 0,20 & 0,10 & 1,13 & 2,48 \\
\hline $20 \mathrm{Abr}-18 \mathrm{Mai}$ & 0,30 & 1,88 & 1,15 & 2,20 \\
\hline $18 \mathrm{Mai}-9$ Jun & 0,00 & 9,03 & 11,05 & 19,85 \\
\hline 9 Jun -13 Jul & 1,50 & 2,50 & 6,07 & 16,67 \\
\hline $13 \mathrm{Jul}-2 \mathrm{Set}$ & 3,20 & 6,23 & 32,03 & 57,70 \\
\hline $2-23$ Set & 3,15 & 9,43 & 8,30 & 20,93 \\
\hline 23 Set -18 Out & 12,40 & 8,26 & 20,53 & 15,80 \\
\hline 18 Out $-26 \mathrm{Nov}$ & 14,45 & 6,56 & 16,35 & 17,10 \\
\hline $26 \mathrm{Nov}-5 \mathrm{Jan} / 00$ & 6,52 & 10,96 & 13,58 & 13,70 \\
\hline Média & 2,60 & 3,34 & 6,95 & 15,72 \\
\hline
\end{tabular}




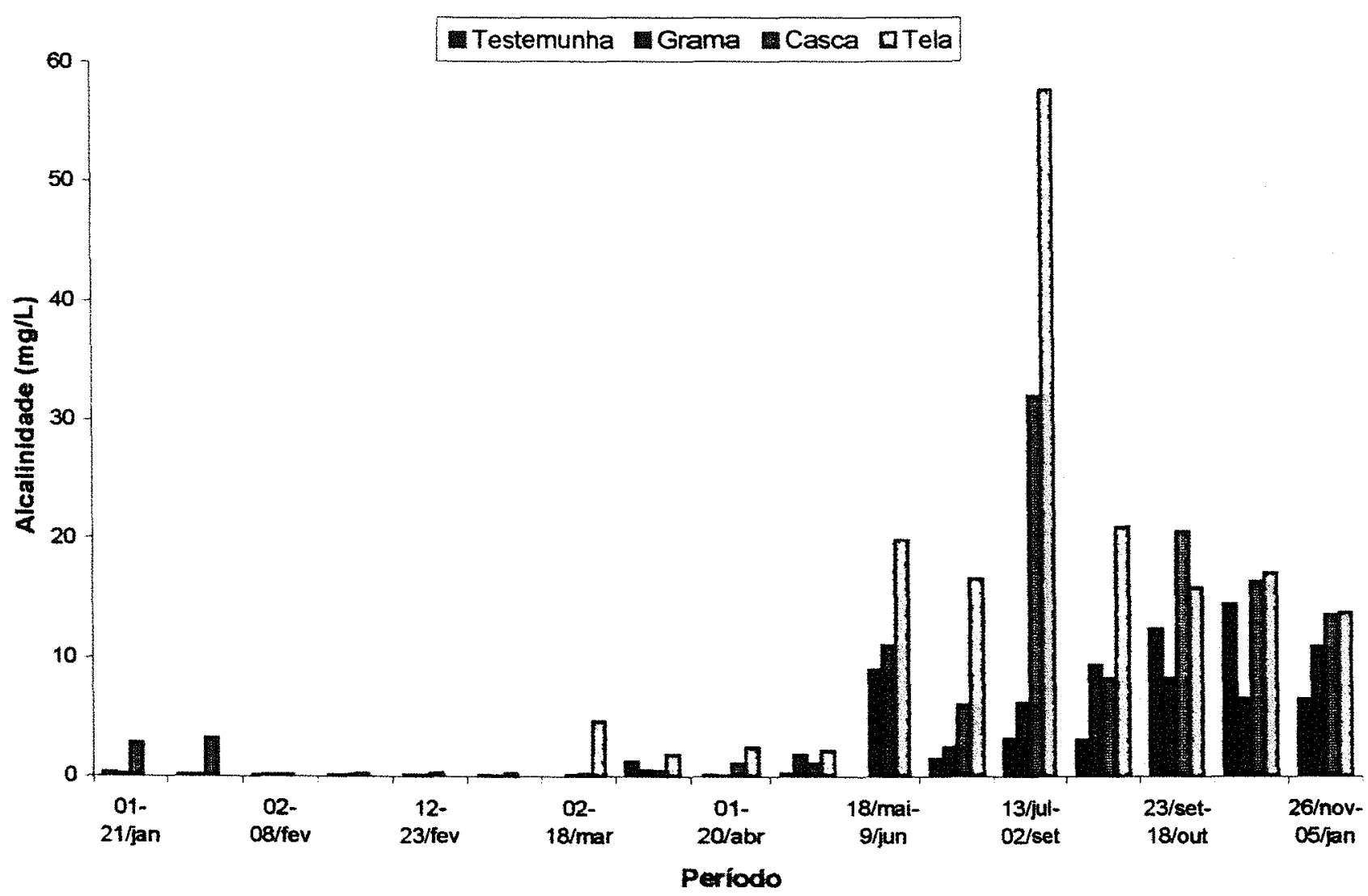

Figura 16. Valores médios de alcalinidade $(\mathrm{mg} / \mathrm{L})$ para os tratamentos analisados.

$\mathrm{O} \mathrm{pH}$ indica a atividade do íon hidrogênio na amostra de água. Através da Tabela 21 e da Figura 17, nota-se que os maiores valores médios ocorreram nos tratamentos D (tela vegetal) e C (casca), muito próximos um do outro, seguidos por B (grama) e A (testemunha). Os valores apresentados por estes dois últimos tratamentos foram os que mais aproximaram-se do valor médio da água da chuva $(5,0)$, que pode ser observado na Tabela 16. 
Tabela 21. Valores médios de $\mathrm{pH}$ para os tratamentos analisados.

\begin{tabular}{ccccc}
\hline Período & Testemunha & Grama & Casca & Tela \\
\hline 1 - 21 Jan/99 & 4,9 & 5,4 & 6,8 & - \\
21 Jan - 2 Fev & 5,4 & 5,7 & 6,8 & - \\
2 - 8 Fev & 5,2 & 5,3 & 6,1 & - \\
$8-12 \mathrm{Fev}$ & 5,0 & 5,4 & 6,1 & - \\
12 - 23 Fev & 5,1 & 5,0 & 6,0 & - \\
$23 \mathrm{Fev}-2 \mathrm{Mar}$ & 5,0 & 5,3 & 6,2 & - \\
2 - 18 Mar & 3,3 & 4,6 & 6,4 & 4,3 \\
$18 \mathrm{Mar}-1 \mathrm{Abr}$ & 3,9 & 4,2 & 5,4 & 6,8 \\
1 - 20 Abr & 4,4 & 4,0 & 5,6 & 6,5 \\
20 Abr - 18 Mai & 4,7 & 6,1 & 6,4 & 6,5 \\
18 Mai - 9 Jun & 3,5 & 5,6 & 4,7 & 6,4 \\
$9 \mathrm{Jun}-13 \mathrm{Jul}$ & 3,9 & 4,1 & 4,8 & 5,3 \\
13 Jul - 2 Set & 5,1 & 5,0 & 7,4 & 7,1 \\
2 - 23 Set & 4,7 & 5,5 & 6,4 & 6,2 \\
23 Set - 18 Out & 6,9 & 6,4 & 7,1 & 6,8 \\
18 Out - 26 Nov & 6,0 & 5,9 & 6,6 & 6,4 \\
26 Nov - 5 Jan/00 & 6,6 & 6,7 & 6,7 & 7,0 \\
\hline Média & 4,9 & 5,3 & 6,2 & 6,3 \\
\hline
\end{tabular}




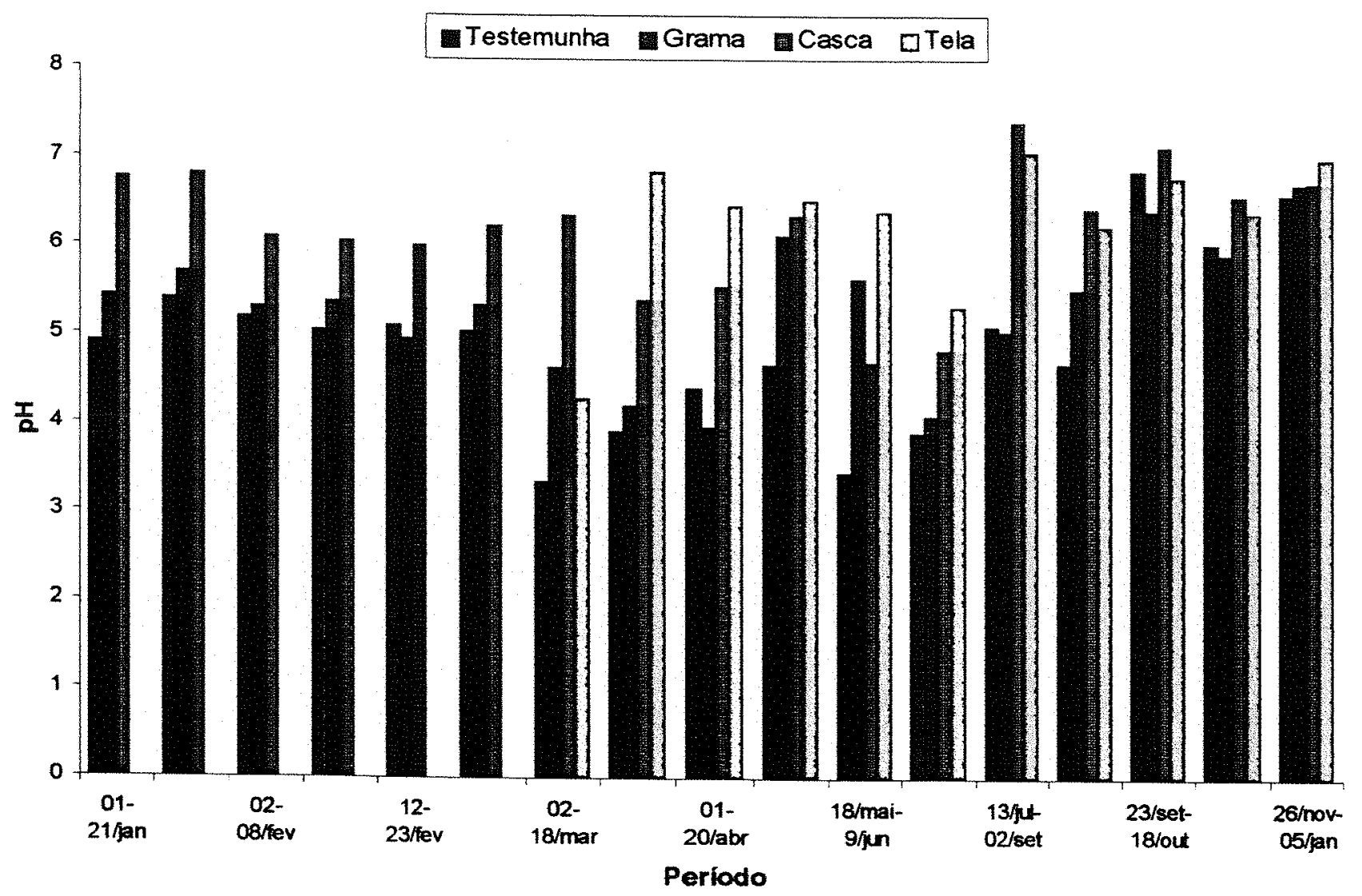

Figura 17. Valores médios de $\mathrm{pH}$ para os tratamentos analisados.

Como jả foi comentado anteriormente, foi necessária a colocação de estacas de bambu para manter os tratamentos B (grama) e C (casca) fixos no talude, e grampos de fixação no tratamento $D$ (tela vegetal), pois a declividade média do local do experimento era bastante elevada. Recomenda-se a utilização destes materiais no caso de, futuramente, algum destes tratamentos ser empregado em áreas declivosas. Porém, no caso da casca de Eucalyptus spp. picada ser aplicada em grandes áreas declivosas, pode ficar sujeita a deslizamentos, mesmo com a colocação das estacas, tornando 
recomendável a realização de novos estudos em parcelas maiores para conferir a viabilidade do uso desta cobertura.

No caso da casca de eucalipto picada, recomenda-se a redução da espessura de 10 para $5 \mathrm{~cm}$, diminuindo pela metade a taxa de aplicação, e a adição de sementes de gramíneas e leguminosas, para que após a degradação da casca a área permaneça coberta, agora com vegetação. Além disso, com a utilização deste expediente economiza-se na quantidade de material, tornando possivel a cobertura do dobro da área com a mesma quantidade de casca empregada anteriormente.

No tratamento onde a cobertura usada foi a tela vegetal, a recomendação é que se utilize somente uma camada do material. Neste experimento foram colocadas duas camadas de tela porque, com a colocação de apenas uma, grande parte do solo da parcela permanecia exposto, e avaliou-se que a proteção contra a erosão não seria suficiente. Isto, aliado ao fato de a precipitação ocorrida após a aplicação das sementes de gramíneas e leguminosas (março de 1999) ter sido baixa, fez com que as sementes não germinassem como esperado, apresentando um baixo índice de germinação (Figuras 18 e 19). 


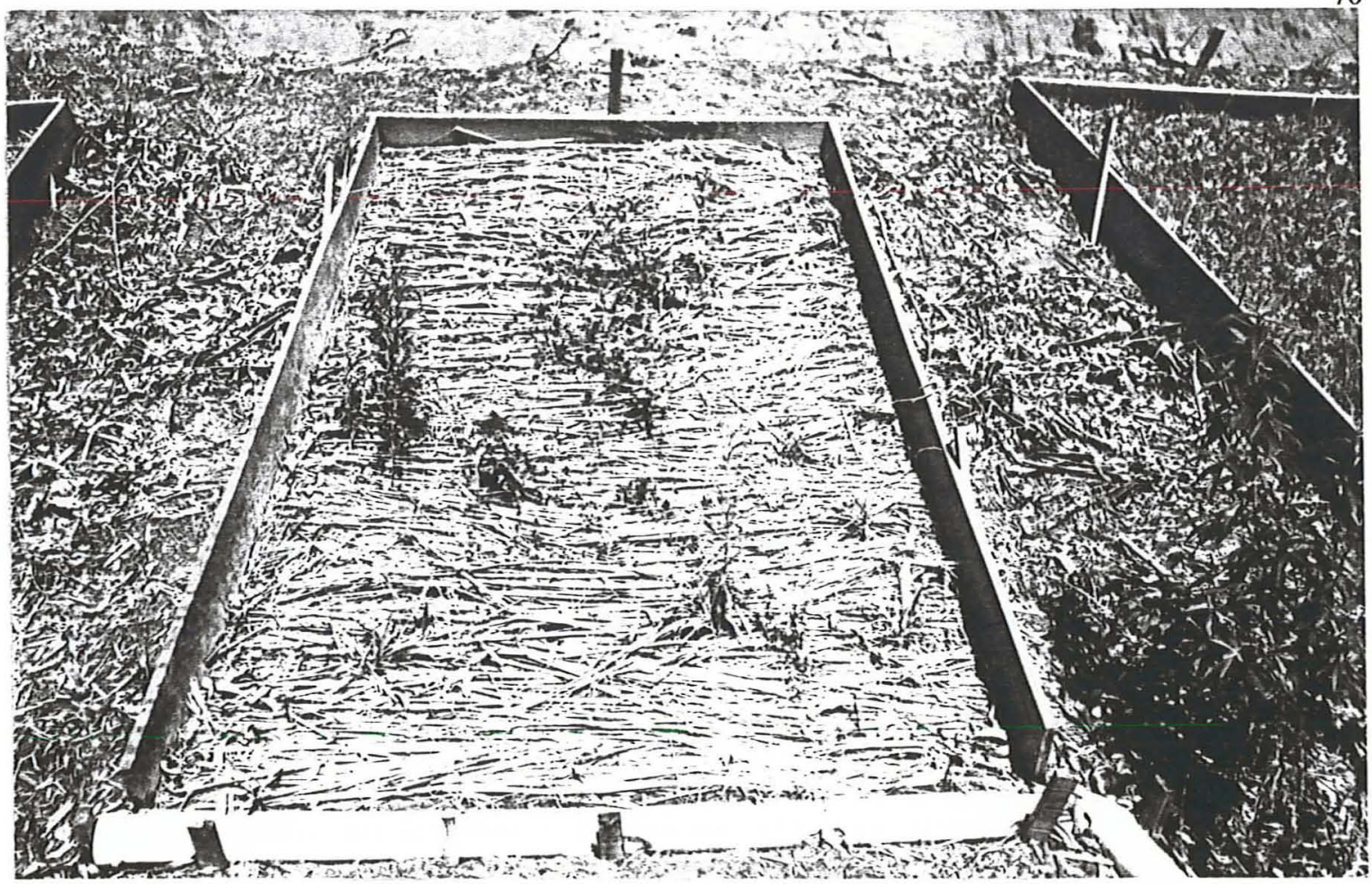

Figura 18. Parcela do Tratamento D (tela vegetal) onde a germinação das sementes foi maior.

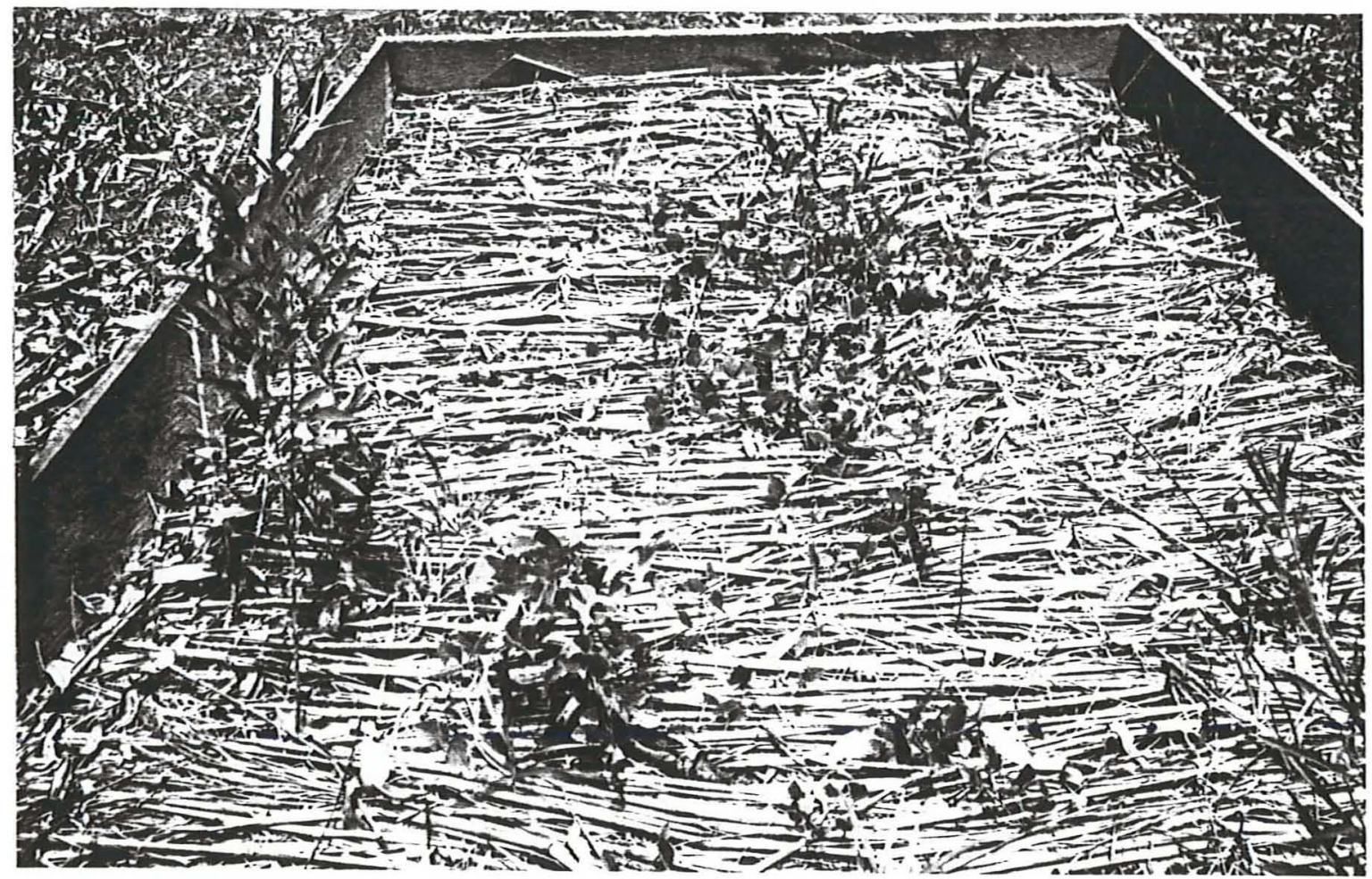

Figura 19. Detalhe da parcela mostrada na figura anterior. 


\subsection{Análise Estatística}

A análise estatística consistiu de análise de variância, teste $\mathrm{F}$ e teste de Tukey, e foi realizada para todos os parâmetros estudados. Os resultados estão contidos nas tabelas a seguir.

Tabela 22. Diferença entre os valores de sedimentos totais considerando somente os valores obtidos a partir do mês de março/1999, quando todos os tratamentos estavam instalados.

\section{Tratamentos}

\begin{tabular}{ccccc}
\hline & A & B & C & D \\
A & - & $5,3^{*}$ & $6,1^{*}$ & $4,4^{*}$ \\
B & $5,3^{*}$ & - & 0,8 & 0,9 \\
C & $6,1^{*}$ & 0,8 & - & 1,7 \\
D & $4,4^{*}$ & 0,9 & 1,7 & - \\
\hline
\end{tabular}

* representa valor significativo a $5 \%$

Tabela 23. Diferença entre os valores de sedimentos totais considerando todos os valores obtidos no experimento, excetuando-se o Tratamento D (tela vegetal).

\begin{tabular}{cccc}
\hline \multicolumn{4}{c}{ Tratamentos } \\
\hline A & B & C \\
A & - & $46,3^{*}$ & $51,7^{*}$ \\
B & $46,3^{*}$ & - & 5,4 \\
C & $51,7^{*}$ & 5,4 & - \\
\hline
\end{tabular}

* representa valor significativo a $5 \%$

De acordo com as Tabelas 22 e 23, nos dois casos acima apenas a testemunha apresentou diferença significativa em relação aos demais tratamentos, que não diferiram entre si, com $95 \%$ de probabilidade. 
Tabela 24. Diferença entre os valores de escoamento superficial considerando somente os valores obtidos a partir do mês de março/1999, quando todos os tratamentos estavam instalados.

\begin{tabular}{ccccc}
\hline \multicolumn{5}{c}{ Tratamentos } \\
\hline A & A & B & C & D \\
B & - & 5,2 & 25,5 & 5,6 \\
C & 5,2 & - & 20,3 & 10,8 \\
D & 25,5 & 20,3 & - & 31,0 \\
\hline
\end{tabular}

${ }^{*}$ representa valor significativo a $5 \%$

Tabela 25. Diferença entre os valores de escoamento superficial considerando todos os valores obtidos no experimento, excetuando-se o Tratamento D (tela vegetal).

\begin{tabular}{cccc}
\hline \multicolumn{4}{c}{ Tratamentos } \\
\hline A & A & B & C \\
B & - & 1,5 & 16,2 \\
C & 1,5 & - & 14,7 \\
\hline
\end{tabular}

* representa valor significativo a $5 \%$

Observando-se as Tabelas 24 e 25 percebe-se que em ambos os casos não existiu diferença significativa entre os tratamentos estudados no que diz respeito ao escoamento superficial, com $95 \%$ de probabilidade. 
Tabela 26. Diferença entre os valores de cor considerando somente os valores obtidos a partir do mês de março/1999, quando todos os tratamentos estavam instalados.

\section{Tratamentos}

\begin{tabular}{ccccc}
\hline & A & B & C & D \\
A & - & 83,1 & 137,9 & $160,3^{*}$ \\
B & 83,1 & - & 54,8 & 77,2 \\
C & 137,9 & 54,8 & - & 22,4 \\
D & $160,3^{*}$ & 77,2 & 22,4 & - \\
\hline
\end{tabular}

* representa valor significativo a $5 \%$

Tabela 27. Diferença entre os valores de cor considerando todos os valores obtidos no experimento, excetuando-se o Tratamento $\mathrm{D}$ (tela vegetal).

\begin{tabular}{cccc}
\hline \multicolumn{4}{c}{ Tratamentos } \\
\hline A & - & B & C \\
B & 117,5 & 117,5 & $151,0^{*}$ \\
C & $151,0^{*}$ & - & 33,5 \\
\hline
\end{tabular}

* representa valor significativo a $5 \%$

Através da Tabela 26 nota-se que, com todos os tratamentos instalados, somente houve diferença estatística significativa para os valores de cor entre os tratamentos testemunha e tela vegetal. Já pela Tabela 27 , correspondente a todas as coletas de material realizadas, conclui-se que estatisticamente, ao nível de $95 \%$ de significância, houve diferença somente entre a testemunha e a casca. 
Tabela 28. Diferença entre os valores de condutividade elétrica considerando somente os valores obtidos a partir do mês de março/1999, quando todos os tratamentos estavam instalados.

\section{Tratamentos}

\begin{tabular}{ccccc}
\hline & A & B & C & D \\
A & - & 0,01 & 0,02 & 0,01 \\
B & 0,01 & - & 0,01 & 0 \\
C & 0,02 & 0,01 & - & 0,03 \\
D & 0,01 & 0 & 0,03 & - \\
\hline
\end{tabular}

* representa valor significativo a $5 \%$

Tabela 29. Diferença entre os valores de condutividade elétrica considerando todos os valores obtidos no experimento, excetuando-se o Tratamento D (tela vegetal).

\begin{tabular}{cccc}
\hline \multicolumn{3}{c}{ Tratamentos } & C \\
\hline A & A & B & 0,04 \\
B & - & 0,02 & 0,02 \\
C & 0,02 & - & - \\
\hline
\end{tabular}

* representa valor significativo a $5 \%$

Em ambos os casos não houve diferença estatística significativa na condutividade elétrica entre os tratamentos analisados (Tabelas 28 e 29). 
Tabela 30. Diferença entre os valores de turbidez considerando somente os valores obtidos a partir do mês de março/1999, quando todos os tratamentos estavam instalados.

\section{Tratamentos}

\begin{tabular}{ccccc}
\hline & A & B & C & D \\
A & - & $120,2^{*}$ & $184,5^{*}$ & $98,7^{*}$ \\
B & $120,2^{*}$ & - & 64,3 & 21,5 \\
C & $184,5^{*}$ & 64,3 & - & 85,8 \\
D & $98,7^{*}$ & 21,5 & 85,8 & - \\
\hline
\end{tabular}

* representa valor significativo a $5 \%$

Tabela 31. Diferença entre os valores de turbidez considerando todos os valores obtidos no experimento, excetuando-se o Tratamento D (tela vegetal).

\begin{tabular}{cccc}
\hline \multicolumn{4}{c}{ Tratamentos } \\
\hline A & - & B & C \\
A & 33,9 & 33,9 & 122,3 \\
B & 122,3 & - & 88,4 \\
C & 88,4 & - \\
\hline
\end{tabular}

* representa valor significativo a $5 \%$

Analisando a Tabela 30 conclui-se que, quando todos os tratamentos estavam instalados, o Tratamento A (testemunha) foi diferente dos demais quanto à turbidez, e estes não diferiram entre si ao nível de $95 \%$ de probabilidade. Quando não se considera o Tratamento $\mathrm{D}$ (tela vegetal), todos os tratamentos foram iguais estatisticamente. 
Tabela 32. Diferença entre os valores de alcalinidade considerando somente os valores obtidos a partir do mês de março/1999, quando todos os tratamentos estavam instalados

\section{Tratamentos}

\begin{tabular}{ccccc}
\hline & A & B & C & D \\
A & - & 1,0 & 5,6 & $9,0^{*}$ \\
B & 1,0 & - & 4,6 & $7,8^{*}$ \\
C & 5,6 & 4,6 & - & 3,2 \\
D & $9,0^{*}$ & $7,8^{*}$ & 3,2 & - \\
\hline
\end{tabular}

* representa valor significativo a $5 \%$

Tabela 33. Diferença entre os valores de alcalinidade considerando todos os valores obtidos no experimento, excetuando-se o Tratamento D (tela vegetal).

\begin{tabular}{cccc}
\hline \multicolumn{5}{c}{ Tratamentos } & C \\
\hline A & A & B & 3,7 \\
B & - & 0,6 & 3,1 \\
C & 0,6 & - & - \\
\hline
\end{tabular}

* representa valor significativo a $5 \%$

Quando são comparados todos os tratamentos a partir de março/1999, com todos eles instalados (Tabela 32), nota-se que, com 95\% de probabilidade, somente a tela vegetal se diferenciou estatisticamente dos demais. No caso da comparação feita somente entre a testemunha, grama e casca em todo o periodo experimental (Tabela 33), chega-se à conclusão de que não existiu diferença estatística significativa entre os tratamentos. 
Tabela 34. Diferença entre os valores de $\mathrm{pH}$ considerando somente os valores obtidos a partir do mês de março/1999, quando todos os tratamentos estavam instalados.

\begin{tabular}{ccccc}
\hline \multicolumn{5}{c}{ Tratamentos } \\
\hline A & A & B & C & D \\
B & - & 1,2 & 0,7 & 1,4 \\
C & 1,2 & - & 0,5 & 0,2 \\
D & 0,7 & 0,5 & - & 0,7 \\
\hline
\end{tabular}

* representa valor significativo a $5 \%$

Tabela 35. Diferença entre os valores de $\mathrm{pH}$ considerando todos os valores obtidos no experimento, excetuando-se o Tratamento D (tela vegetal).

\begin{tabular}{cccc}
\hline \multicolumn{5}{c}{ Tratamentos } & C \\
\hline A & A & B & 0,4 \\
B & - & 0,3 & 0,1 \\
C & 0,3 & - & - \\
\hline
\end{tabular}

* representa valor significativo a $5 \%$

Em ambos os casos não houve diferença estatística significativa no $\mathrm{pH}$ entre os tratamentos analisados (Tabelas 34 e 35). 


\subsection{Avaliação Econômica}

\subsubsection{Experimento}

A instalação da parte estrutural (tábuas, tubos de PVC e recipientes de coleta) foi realizada por 8 pessoas em um dia de trabalho. Os tratamentos grama e casca foram instalados pelas mesmas 8 pessoas em dois dias de trabalho. Já a tela vegetal foi instalada por 3 pessoas em um dia de trabalho. $O$ custo da mão-de-obra nos três casos foi de $R \$ 45,00 /$ homem/dia, resultando em um custo final de mão-de-obra de R\$1.215,00.

Cada cobertura empregada neste experimento cobriu uma área total de $35 \mathrm{~m}^{2}$. O tratamento B (grama) apresentou um custo de $\mathrm{R} \$ 3,00 / \mathrm{m}^{2}$, resultando em $\mathrm{R} \$ 105,00$. A quantidade utilizada do tratamento $C$ (casca) foi de $3,5 \mathrm{~m}^{3}$ (camada de $0,10 \mathrm{~m}$ de espessura), mas, por ser um resíduo da indústria de papel e celulose, seu custo é nulo. Assim, o custo desta cobertura correspondeu somente ao custo de transporte, que foi de $\mathrm{R} \$ 28,90 /$ hora/caminhão, totalizando R \$28,90. O tratamento $\mathrm{D}$ (tela vegetal) apresentou um custo de $R \$ 4,00 / \mathrm{m}^{2}$, já incluídas as sementes utilizadas, o que resulta em um custo final de $R \$ 140,00$.

De acordo com os números acima descritos, o custo total dos tratamentos empregados neste experimento foi de R\$ $1.488,90$. Não foram considerados os custos das tábuas, tubos de PVC e recipientes de coleta, já que em uma eventual utilização dos tratamentos no campo estas estruturas não serão necessárias.

\subsubsection{Instalação dos tratamentos em uma área de 1 ha a uma distância de} 20 km

Os custos da grama e da tela vegetal continuam os mesmos $\left(R \$ 3,00 / \mathrm{m}^{2}\right.$ e $\mathrm{R} \$ 4,00 / \mathrm{m}^{2}$, respectivamente, já incluindo o custo da mão-de-obra). $\mathrm{O}$ custo do transporte da casca da fábrica ao local do experimento, por ultrapassar a distância de 
$10 \mathrm{~km}$, corresponde a R\$1,10/km rodado/caminhão. Como será necessária a utilização de $1000 \mathrm{~m}^{3}$ de casca (camada de $10 \mathrm{~cm}$ de espessura) e os caminhões empregados no transporte possuem uma capacidade de $12 \mathrm{~m}^{3}$, conclui-se que deverão ser realizadas 84 viagens, a um custo de $R \$ 3.696,00$. Sendo a casca uma cobertura nova, para o cálculo do custo da mão-de-obra empregada para sua instalação utilizou-se como referência o rendimento médio de aplicação da grama "Batatais" em locais declivosos, que corresponde a 2 pessoas para instalar $100 \mathrm{~m}^{2}$ em 3 dias, considerando também a colocação das estacas. Assim, somando-se ao custo de transporte do material (R\$0,37) o custo da mão-de-obra ( $\mathrm{R} \$ 2,70)$, chega-se à conclusão de que o custo total da casca é de $\mathrm{R} \$ 3,07 / \mathrm{m}^{2}$. Na Tabela 36 encontra-se um resumo dos custos dos tratamentos analisados.

Tabela 36. Custos das coberturas analisadas.

\begin{tabular}{cc}
\hline Tratamento & Custo $\left(\mathrm{R} \$ / \mathrm{m}^{2}\right)$ \\
\hline Grama & 3,00 \\
Casca & 3,07 \\
Tela & 4,00 \\
\hline
\end{tabular}

Percebe-se que a grama e casca possuem custos próximos, e menores do que o da tela vegetal, correspondendo, respectivamente, a $75 \%$ e $76 \%$ do custo da tela. Como o custo de construção de uma estrada florestal na região de Jacareí é de R\$4.000,00/km, é possível calcular o aumento neste custo representado pelas coberturas do solo. Considerando uma estrada de $1 \mathrm{~km}$ de extensão com um talude de $2 \mathrm{~m}$ de largura e uma declividade de aproximadamente $85 \%$, tem-se que a grama, a casca e a tela elevam o custo de construção da estrada em, respectivamente, $150 \%, 153,5 \%$ e $200 \%$. 


\section{CONCLUSÕES}

Observando-se os dados contidos nas tabelas e gráficos no item anterior, assim como a avaliação econômica, pode-se chegar às seguintes conclusões:

- como não houve diferença estatística significativa, os três tipos de cobertura do solo utilizados (grama "Batatais", casca de eucalipto picada ou tela vegetal impregnada com sementes de gramíneas e leguminosas) são eficientes no controle da erosão em taludes de estradas florestais, se comparados com o tratamento testemunha, ou seja, o emprego de qualquer das coberturas é indicado para controlar a erosão;

- assim, para decidir qual das coberturas do solo deve ser utilizada em uma área em particular, deve-se analisar a avaliação econômica e a facilidade de instalação. Economicamente, a cobertura de maior custo é a tela vegetal;

- a grama "Batatais" é de fácil instalação, proporciona uma redução satisfatória na produção de sedimentos e possui o menor custo entre as coberturas analisadas. Sua desvantagem é a demora no estabelecimento, pois levou sete meses para atingir a totalidade de cobertura da parcela;

- a principal desvantagem da casca é a dificuldade na instalação, especialmente em locais muito declivosos. Porém, com a colocação de estacas de bambu ou madeira, o problema é resolvido satisfatoriamente. Seu custo é praticamente igual ao da grama, devido principalmente ao custo da mão-de-obra empregada, pois o material em si, no caso das indústrias de papel e celulose, não apresenta custo, por ser um resíduo da produção;

- a tela vegetal foi a cobertura de mais fácil e rápida instalação, mas seu custo é o mais alto entre os tratamentos estudados e a redução na perda de sedimentos foi a menor entre os tratamentos analisados; 
- assim, a melhor cobertura do solo é a casca de Eucalyptus spp., já que seu custo está entre os mais baixos e proporcionou uma ótima redução na produção de sedimentos em taludes de estradas florestais;

- os resultados obtidos neste trabalho, em taludes de estradas florestais, demonstram que coberturas orgânicas são eficientes para coibir a perda de solo por erosão, reforçando a necessidade de manutenção da casca e de outros resíduos no terreno, principalmente em locais declivosos e no caso de sistema de colheita com corte raso da floresta. 


\section{REFERÊNCIAS BIBLIOGRÁFICAS}

ABE, K.; ZIEMER, R. R. Effect of Tree Roots on a Shear Zone: Modeling Reinforced Shear Stress. Canadian Journal of Forest Research, v. 21, n. 7, p. 1012-9, jul. 1991.

ADAMOVICH, L. Historical Perspective of Forest Road Development in British Columbia, Vancouver: UBC, 1971. 17 p.

ADAMOVICH, L. Geometric Design Standarts of Forest Roads: an Aesthetic View, Vancouver: UBC, 1971. $13 \mathrm{p}$.

AMERICAN PUBLIC HEALTH ASSOCIATION. Standard Methods for the Examination of Water and Wastewater. 14 ed., Washington: APHA, 1976. $1193 \mathrm{p}$.

ASKEN, G. R.; WILLIAMS, T. M. Sediment Concentrations from Intensively Prepared Wetland Sites. Southern Journal of Applied Forestry, v. 8, n. 3, p. 152-7, ago 1984.

BALDOCEDA ASTETE, R. Evaluación de la Escorrentia Superficial y Erosión Hidrica en Terrenos de Pendiente, con Diferentes Tipos de Cobertura Vegetal en el Valle de Chanchamayo-Junín. Huancayo: UNCP, 1985. 121 p. 
BELT, G. H.; WOO, B. M. An Analysis of Landslide Damage and Slope Stabilization Near Seoul, Korea. Moscow: University of Idaho, 1979. 9 p.

BERTONI, J.; LOMBARDI NETO, F. Conservação do solo. 3 ed. São Paulo: Ícone, 1990. 355 p.

BLAUER, A. C.; McARTHUR, E. D.; STEVENS, R.; NELSON, S. D. Evaluation of Roadside Stabilization and Beautification Plantings in South-Central Utah. USDA Forest Service INT Research Paper, n. 462, p. 1-65, mar. 1993.

BONELL, M. Progress in Runoff and Erosion Research in Forests. In: WORLD FORESTRY CONGRESS, 10, Paris, 1991. Proceedings. Paris: RFF, 1991. v. $2, \mathrm{p} \mathrm{101-38.}$

BRASIL. Ministério da Agricultura. Secretaria Nacional de Planejamento Agrícola. Aptidão Agrícola das Terras de São Paulo. Brasília: BINAGRI, v. 20, 1979. $111 \mathrm{p}$.

BRASIL. Ministério das Minas e Energia. Projeto RADAM BRASIL. Folha SF 23/24 - Rio de Janeiro/Vitória. Rio de Janeiro, 1983, v. 32. 780 p.

BURROUGHS, E. R.; KING, J. G. Reduction of Soil Erosion on Forest Roads. USDA Forest Service INT General Technical Report, n. 264, p 1-21, jul 1989.

CÂMARA, C. D. Efeitos do Corte Raso do Eucalipto sobre o Balanço Hídrico e a Ciclagem de Nutrientes em uma Microbacia Experimental. Piracicaba, 1999. 87 p. Dissertação (Mestrado) - Escola Superior de Agricultura "Luiz de Queiroz", Universidade de São Paulo. 
CARTER, M. R.; GARDNER, R. B.; BROWN, D. B. Optimum Economic Layout of Forest Harvesting Work Roads. USDA Forest Service INT Research Paper, n. 133, p. 1-13, fev. 1973.

CASSELS, D. S.; GILMOUR, D.A.; BONELL, M. Catchment Response and Watershed Management in the Tropical Rainforests of North-Eastern Australia. Forest Ecology and Management, v. 10, n. 1/2, p. 155-75, fev. 1985.

CHANG, M. Laboratoty Notes: Forest Hydrology. Nacogdoches: School of Forestry, 1982. $213 \mathrm{p}$.

COELHO, A. T. Nova Tecnologia para Controle de Erosão. Folha Florestal, n. 90, p. 10-12, mar./abr. 1998.

COELHO, S. J. Influência do Tipo de Muda, Espaçamento e Adubação Fosfatada na Formação de Gramado com Grama Batatais (Paspalum notatum Flügge). Lavras, 1994. 79 p. Dissertação (M. S.) - Escola Superior de Agricultura de Lavras.

DEFLOR. Descrição dos Produtos/Serviços e sua Respectiva Aplicação. Belo Horizonte, 1998. 4 p.

DERSA. Manual de Revestimento Vegetal Rodoviário. São Paulo, 1975. 130 p.

DIETZ, P., GRAMMEL, R.; MALINOVSKI, J. R. Curso de Atualização sobre Sistemas de Exploração e Transporte Florestal: 4. Curitiba: UFPR, 1983. $158 \mathrm{p}$. 
DUARTE, J.; BERGER, R. Investimentos em Estradas Florestais: uma Análise de sua Economicidade. In: ENCONTRO BRASILEIRO DE ECONOMIA FLORESTAL, 1, Curitiba, 1988. Anais. Curitiba: EMBRAPA/CNPF, 1988. v.2, p. 99-114.

DURÁN, S. P. Metodologias de Prediccion de Perdidas de Suelo por Erosion Hidrica. Ciencia e Investigacion Forestal, v. 6, n. 1, p. 99-115, jun. 1992.

FAO. Watershed Management Field Manual: Road Design and Construction in Sensitive Watersheds. Roma: FAO, 1989. 218 p.

FAO. Planning Forest Roads and Harvesting Systems. Roma: FAO, 1977, v. 2, $158 \mathrm{p}$.

GONSOIR, M. J.; GARDNER, R. B. Investigation of Slope Failures in the Idaho Batholith. USDA Forest Service INT Research Paper, n. 97, p. 1-34, 1971.

GRACE III, J. M.; WILHOIT, J.; RUMMER, R.; STOKES, B. Surface Erosion Control Techniques on Newly Constructed Forest Roads. In: ASAE ANNUAL INTERNATIONAL MEETING, Phoenix, 1996, 14 p.

GREY, D. C. Principles and Elements of Monitoring in Mountain Catchment Areas: Soils and Erosion. South African Forestry Journal, v. 144, p. 47-51, mar. 1988.

HEWLETT, J. D. Principles of Forest Hydrology. Athens: University of Georgia Press, 1982. $191 \mathrm{p}$.

HEWLLET, J. D.; DOSS, R. Forests, Floods, and Erosion: A Watershed Experiment in the Southeastern Piedmont. Forest Science, v. 30, n. 2, p. 424-34, jun. 1984. 
HENDERSON, G. S.; WITTHAWATCHUTIKUL, P. The Effect of Road Construction on Sedimentation in a Forested Catchment at Rayong, Thailand. In: SYMPOSIUM ON EFFECTS OF FOREST LAND USE ON EROSION AND SLOPE STABILITY, Honolulu, 1984. p. 247-53.

KANTOLA, M.; HARSTEla, P. Handbook on Appropriate Technology for Forestry Operations in Developing Countries: Part 2. Helsinki: FTD, 1988. $192 \mathrm{p}$.

KIDD, W. J.; MEGAHAN, W. F. Effect of Logging Roads on Sediment Production Rates in the Idaho Batholith. USDA Forest Service INT Research Paper, n. 123 , p. $1-14,1972$.

KIDD JR, W. E.; PATRIC, J. H. Erosion Caused by Low-Cost Roads in the Eastern Forest. In: SYMPOSIUM ON ENGINEERING SYSTEMS FOR FOREST REGENERATION, 1981. s. 1.

LAYTON, D. A.; LeDOUX, C. B.; HASSLER, C. C. Cost Estimators for Construction of Forest Roads in Central Appalachians. USDA Forest Service NE Research Paper, n. 665, p. 1-4, jul. 1992.

LIMA, W. de P. Impacto Ambiental do Eucalipto. São Paulo: EDUSP, 1996. 301 p.

LIMA, W. de P. Hidrologia Florestal Aplicada ao Manejo de Bacias Hidrográficas. Piracicaba: USP/ESALQ. Departamento de Ciências Florestais, 1996. 318p.

MACHADO, C. C. Sistema Brasileiro de Classificação de Estradas Florestais (SIBRACEF): Desenvolvimento e Relação com o Meio de Transporte Florestal Rodoviário. Curitiba: UFPR, 1989. 211 p. Tese (Doutorado) - Universidade Federal do Paraná. 
MACHADO, C. C.; SOUZA, A. P. de. Impacto Ambiental das Estradas Florestais no Ecossistema: Causas e Controle. Boletim Técnico Sociedade de Investigações Florestais, n. 1, p. 1-12, mai. 1990.

MEGAHAN, W. F. Reducing Erosional Impacts of Roads. In: FAO Conservation Guide: Guidelines for Watershed Management. Roma: FAO, 1977. cap. 14, p. 237-261.

NASCIMENTO, C. M.; PEREIRA, M. A. de M. G. Atlas Climatológico do Estado de São Paulo (1977 - 1988). Campinas: Fundação Cargill, 1988. 93 p.

NEARY, D. G. \& HORNBECK, J. W. Impacts of Harvesting and Associated Practices on Off-site Environmental Quality. In: Impacts of Forest Harvesting on Longterm Site Productivity. Londres: Chapman \& Hall, 1994. cap. 4, p. 81-119.

OLIVEIRA, L. C. Influência do Percentual de Inclinação das Estradas Florestais na Erosão do Solo. In: SEMINARIO INTERNACIONAL DE CAPACITACION EN INVESTIGACION SOBRE APROVECHAMIENTO FORESTAL DE IMPACTO REDUCIDO Y MANEJO DE BOSQUES NATURALES: RESULTADOS. Santa Cruz de la Sierra: BOLFOR/CIFOR/FAO/USAID, 1997. p. 37-41.

ORMACHEA, R. A. M.; LLERENA, P. C. A. Erosion Hidrica en el Bosque Humedo Tropical de Dantas. Revista Forestal del Peru, v. 19, n. 1, p. 19-34, 1992.

PATRIC, J. H.; BRINK, L. K. Soil Erosion and its Control in the Eastern Forest. In: National Conference on Soil Erosion: Prediction and Control. Ankeny: SCSA, p. $362-8,1977.393$ p. 
RANZINI, M. Balanço Hídrico, Ciclagem Geoquímica de Nutrientes e Perdas de Solo em duas Microbacias Reflorestadas com Eucalyptus saligna Smith, no Vale do Paraiba, SP. Piracicaba, 1990. 99 p. Dissertação (Mestrado)-Escola Superior de Agricultura "Luiz de Queiroz", Universidade de São Paulo.

ROBICHAUD, P. R.; FOLTZ, R. B.; BURROUGHS JR, E. R. United States Forest Service Research on Sediment Production from Forest Roads and Timber Harvest Areas. In: WORLD FORESTRY CONGRESS, 10, Paris, 1991. Proceedings. Paris: RFF, 1991. v. 2, p. 187-93.

ROSE, C. W. Erosion and Sedimentation. In: Hydrology and Water Management in the Humid Tropics: Hydrological Research Issues and Strategies for Water Management, Cambridge, 1993, p. 301-43.

SANTOS, A. R. dos; PASTORE, E. L.; AUGUSTO, F.; CUNHA, M. A. Estradas Vicinais de Terra: Manual Técnico para Conservação e Recuperação. São Paulo: IPT, 1985. $140 \mathrm{p}$.

SÃo PAULO (Estado). Departamento de Águas e Energia Elétrica. Coordenadoria de Planejamento, Avaliação e Controle. Caracterização dos Recursos Hídricos no Estado de São Paulo. São Paulo, 1984. 175 p.

SÃO PAULO (Estado). Departamento de Águas e Energia Elétrica. Centro Tecnológico de Hidráulica e Recursos Hídricos. Totais Mensais de Chuva no Estado de São Paulo: 1976 - 1991. São Paulo, 1993. 360 p.

SÃo PAUlo (Estado). Secretaria de Agricultura e Abastecimento. Manual Técnico de Manejo e Conservação do Solo e da Água. São Paulo, 1995. 477 p. 
SEIXAS, F. Mecanização e Exploração Florestal. Piracicaba: USP/ESALQ. Departamento de Ciências Florestais, 1988, 186 p.

ROJAS SEQUERA, D. Influencia de la Lluvia en la Erosion del Suelo. Revista Forestal Venezoelana, v. 23, n. 33, p. 53-69, jan/dez. 1989.

SETOR DE CONSERVAÇÃO DE ESTRADAS DA KLABIN AGRO-FLORESTAL. Normas e Métodos Básicos para Execução de Projetos de Estradas, Telêmaco Borba: Klabin, 1985. 101 p.

SORRENSON, W. J.; MONTOYA, L. J. Implicações Econômicas da Erosão do Solo e do Uso de Algumas Práticas Conservacionistas no Paraná. Londrina: IAPAR, 1989. $110 \mathrm{p}$

SOTO, H. E. La Bio-ingeniería y el Control de la Erosión. Colombia Forestal, v. 3, n. 3, p. 54-9, set. 1987.

SOUZA, A. P. de ; MACHADO, C. C.; GRIFFITH, J. J.; NEVES, A. R. Impactos Ambientais da Exploração Florestal e Procedimentos para seu Controle. Boletim Técnico Sociedade de Investigações Florestais, n. 3, p. 13-24, set. 1991.

VENTURA, A.; BERENGUT, G.; VICTOR, M. A. M. Características Edafo-climáticas das Dependências do Serviço Florestal do Estado de São Paulo. Silvicultura em São Paulo, v. 4/5, n. 4, p. 57-140, 1965/66.

VILLA NOVA, N. A.; SANTOS, J. M. dos; ANGELOCCI, L. R.; OMETTO, J. C. Agrometeorologia. Piracicaba: ESALQ/USP, 1986. 110 p. 
VITAL, A. R. T. Efeito do Corte Raso no Balanço Hídrico e na Ciclagem de Nutrientes em uma Microbacia Reflorestada com Eucalipto. Piracicaba, 1996. 106 p. Dissertação (Mestrado) - Escola Superior de Agricultura "Luiz de Queiroz", Universidade de São Paulo.

YOHO, N. S. Forest Management and Sediment Production in the South: A Review. Southern Journal of Applied Forestry, v. 4, n. 1, p. 27-36, fev. 1980. 